Historic, Archive Document

Do not assume content reflects current scientific knowledge, policies, or practices. 



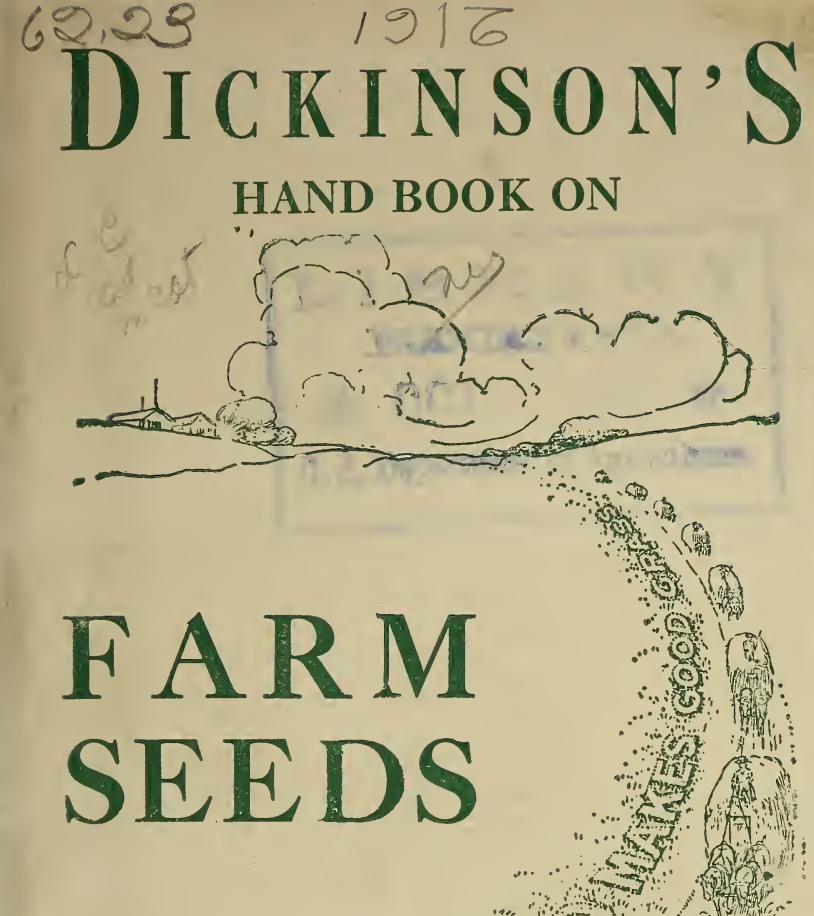

\section{HAND BOOK ON}

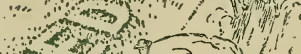

ค. $\quad$ \%

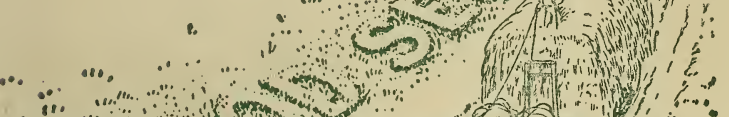
$\therefore$... rii, हुin sts, (1) COMPLIMENTS OF

\section{THE ALBERT DICKINSON CO.} jun CHigrago, del. 


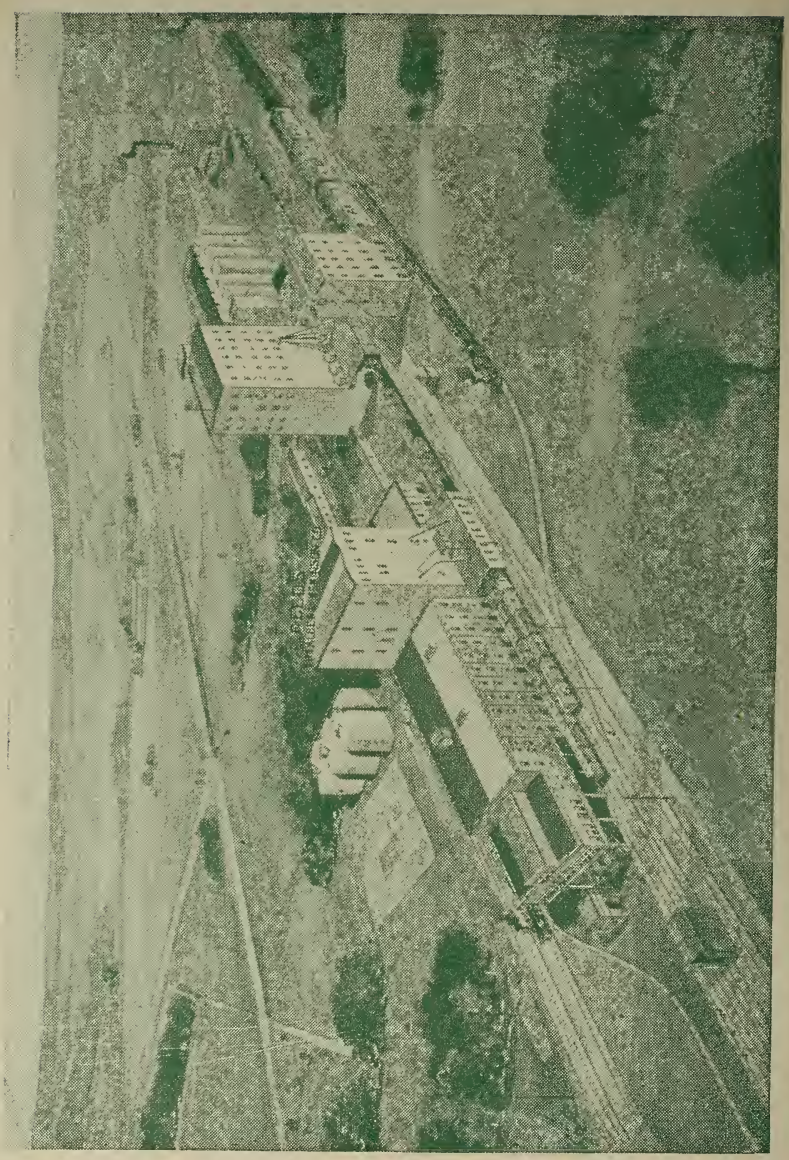

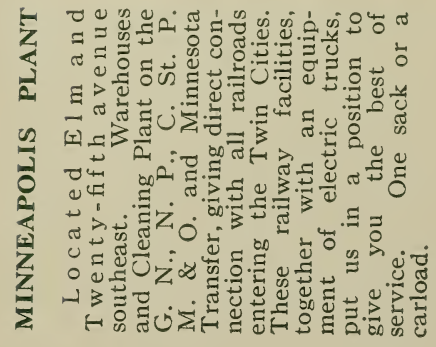




\section{The \\ ALBERT \\ DICKINSON \\ CO.}

\section{CHICAGO \\ MINNEAPOLIS}

Established 1855

BRANCH OFFICES

DETROIT :: BUFFALO :: BOSTON BINGHAMTON :: BALTIMORE 
Copyrighted 1916

The Albert Dickinson Company

Established 1855

Chicago-Minneapolis

First Edition 


\section{Introductory}

In compiling this booklet it is our aim to put into the hands of our friends useful, comprehensive and reliable information, in condensed form, pertaining to the leading varieties of farm seeds. To further assist the grower in the selection of certain crops, we are incorporating cuts made from photographs of typical plants. For much of the information we desire to acknowledge our indebtedness to the United States Department of Agriculture and State Agricultural Experiment Stations, and for the use of many cuts the American Steel and Wire Company, Wisconsin Experiment Station and the United States Department of Agriculture.

Beginning with the initial legislation enacted in this country in relation to the sale of agricultural field seeds, we have been in the forefront in offering seeds which conform to the laws of the several states. As a means to this end we have established one of the best equipped laboratories with the largest corps of graduate and expert seed analysts to be found in any seed establishment.

We believe too much emphasis cannot be laid upon the importance of selecting the purest seed obtainable, for it is universally admitted that results attending the use of high-grade seeds fully justify the slight increase in cost over ordinary qualities. Clean seed means a clean farm. The demand for seed of high purity and germination at moderate cost explains the popularity of our standard trade-mark brands of Timothy, Clover, Alfalfa and other field seeds. 


\section{Our Leading Trade-Mark Brands}

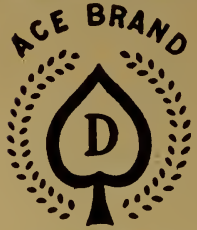

TRADE MARK REG U S.PAT. OFF.

Ace brand Red Clover, Mammoth Clover, Alsike and Fancy Red Top, represents choice quality, strictly re-cleaned seed. Ace brand gives satisfaction. All seed sold under this brand is put up in machine-sewed bags branded with Ace trade-mark.

\section{Pine Tree}

Timothy and other Field seeds offered under this brand are especially selected and re-cleaned for purity. The average purity test of Pine Tree Timothy is $991 / 2 \%$ pure. The genuine is put up only in machine-sewed bags, sewed with red string, and branded with registered Pine Tree trade-mark. Pine Tree brand is not offered in competition with ordinary qualities.

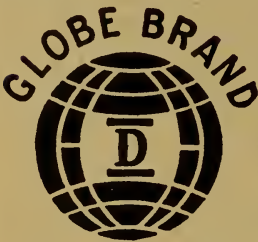

TRADE MARK REG.U.S.PAT.OFF

other qualities. In point of high purity and germination tests and general excellence it represents the very best quality obtainable. When buying Globe brand Timothy, Clover, Mammoth Alsike and Red Top, insist on getting the genuine, which is put up only in machine-sewed bags, sewed with blue string, and branded with registered Globe trademark. 


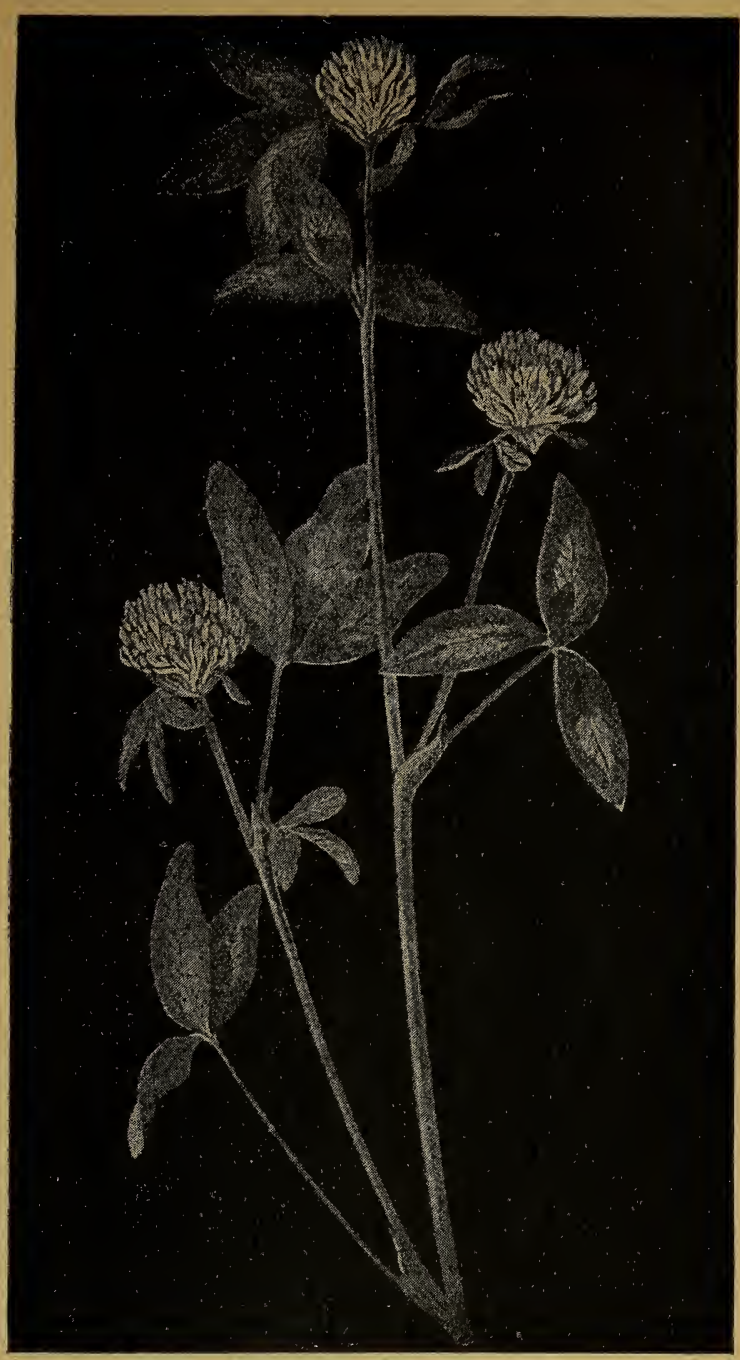

\section{Medium Red Clover}

The Albert Dickinson Co., Chicago-Minneapolis 


\section{Red Clover}

(Trifolium pratense)

Red Clover is utilized both as a hay and a pasture crop, and often as a soiling crop. All young stock make excellent gains on either the pasture or the hay. In addition to its usefulness as a food for animals, it has a very beneficial effect in maintaining in the soil the supply of nitrogen.

Where it is cut for hay and the roots and stubble turned under, it has a marked influence in increasing the yield of succeeding crops.

SOIL-Usually satisfactory crops of Red Clover are produced on soil that will successfully grow corn. Red Clover will not succeed if the ground is poorly drained or if boggy; on such soils it is better to seed Alsike. The limestone areas of the country are well adapted to the production of Red Clover. Where the soil is decidedly deficient in lime, as in many Western States and in some portions of Ohio, Indiana and. Illinois, this mineral should be sufficiently supplied.

PREPARATION OF THE SEED-BEDClover is generally seeded in early spring on winter grain after the late frosts have cracked the ground sufficiently to render natural covering a reasonable certainty. When it is not possible to seed reasonably early, or when the soil is in a honey-comb condition, it is important to cover the seed by drilling it in, or by harrowing it in. If seeded with a spring-sown nurse crop, the preparation accorded the land for the grain crop is sufficient for successful results with Red Clover.

When Red Clover is seeded alone (a very desirable practice on poor, run-down farms) a fine, firm, well-settled seed-bed is essential. If the ground has been previously planted to a cultivated crop, such as corn, plowing is not always necessary, since good disking will generally put the ground in proper condition. It should be remembered

The Albert Dickinson Co., Chicago-Minneapolis 
that Red Clover, especially in its early stages of development, is not drought resistant; in dry seasons, or on land readily affected by droughts, special care should be taken looking to the conservation of moisture in the soil.

SEEDING RED CLOVER-Red Clover may be seeded either broadcast with machine seeders, or by using a regular grain drill with grass seed attachment. Red Clover often fails to catch because it is not planted sufficiently deep, particularly in case of insufficient rainfall. To insure proper moisture conditions in light or sandy soils, the seed should be covered one and one-half to two inches, while in clay soils only about one inch is necessary. The usual rate of seeding is ten pounds per acre.

For prompt germination, it is advisable, on reasonably loose lands, to follow with light harrow to roughen the surface and thus prevent rapid evaporation of the soil moisture.

Red Clover may be seeded in the autumn, about six weeks before frost, or early in the spring while the ground is still freezing and thawing. In seasons where there is ample moisture, or where spring seedings for any particular reason do not succeed, it may be sown in the late spring, after the ground is settled.

For hay, Clover should be cut just after full bluom. It should then be allowed to remain in the swath until the leaves have become well wilted. Later, if weather permits, it is raked into windrows and bunched into cocks. After 36 to 48 hours the cocks are forked over once to prevent heating and later put into the barn.

If harvested at the above stage, a maximum of protein and dry matter is present, the leaves are still intact and the stems green. After this period the leaves begin to fall and the protein content is reduced.

It frequently happens that consideration for success of the second or seed crop makes it necessary to cut the first crop earlier than at the best haying stage. 


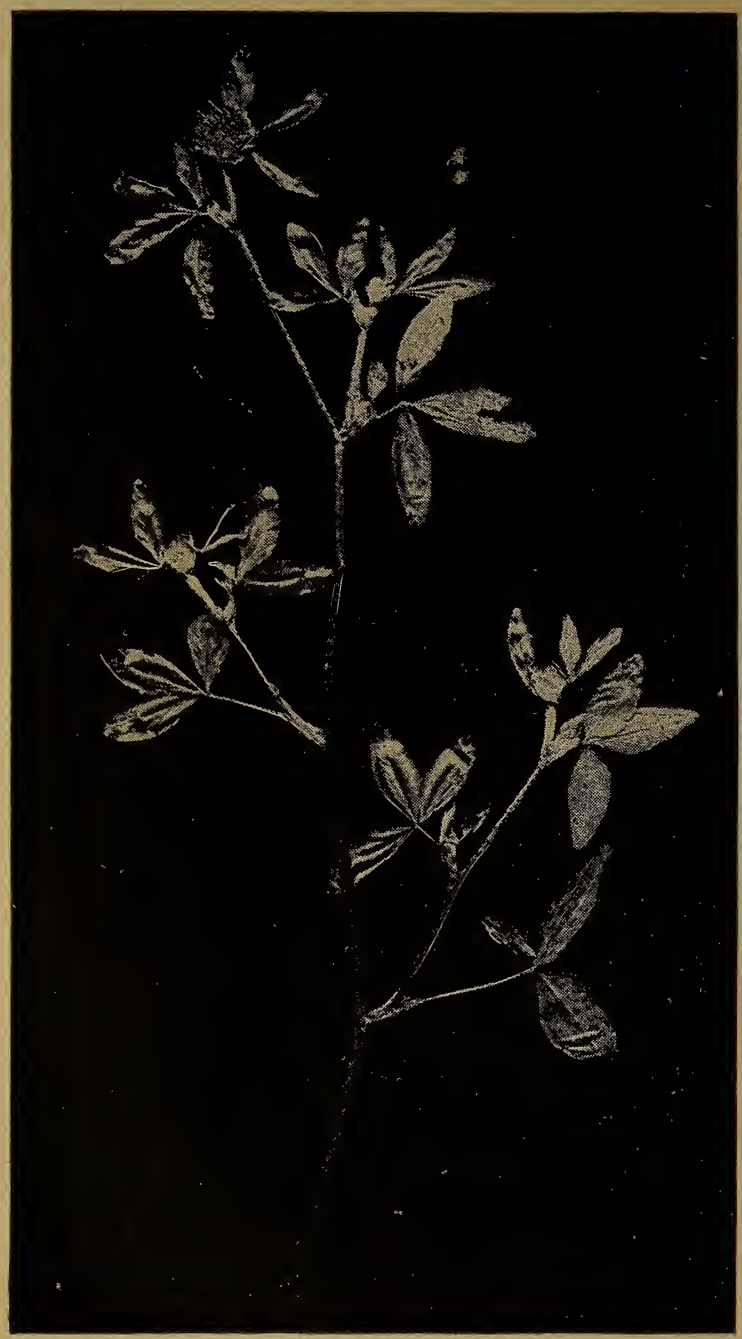

\section{Mammoth Clover}

The Albert Dickinson Co., Chicago-Minneapolis 


\section{Mammoth Glover}

(Trifolium pratense var.)

Mammoth Clover, also known as Sapling Clover, Pea Vine Clover, Bull Clover and Perennial Clover, is a variety of ordinary Red Clover; it matures about two weeks later than ordinary Red Clover; and, in a measure, this fact makes it impracticable to harvest in the same season both a hay crop and a seed crop. In the northern part of the Northern States, where only one crop of ordinary Clover is possible, Mammoth Clover is usually preferred on account of the better yield. No other Clover is equal to Mammoth Clover for hog pastures.

SEEDING-Mammoth Clover is useful in seeding with Timothy for hay, because both bloom at the same time. The larger size of Mammoth Clover plants makes them of slightly greater value than Red Clover as a soil improver. On low ground, the stems of Mammoth Clover are apt to become somewhat woody.

HARVESTING-The variation in time of maturity of Mammoth Clover enables it to avoid many insect pests which greatly injure the fields of ordinary Clover; this item is important in reducing injury from many of the insects which play havoc with the successful production of seed of ordinary Red Clover. On poor, sandy lands in the North, Mammoth Clover gives better results than either Red or Alsike Clover.

If grown for hay, it should be cut when in early bloom, rather than past bloom, on account of the tendency of the stems to become woody. Poor soils are excellent for seed production because of the less plant growth made on such soils. 


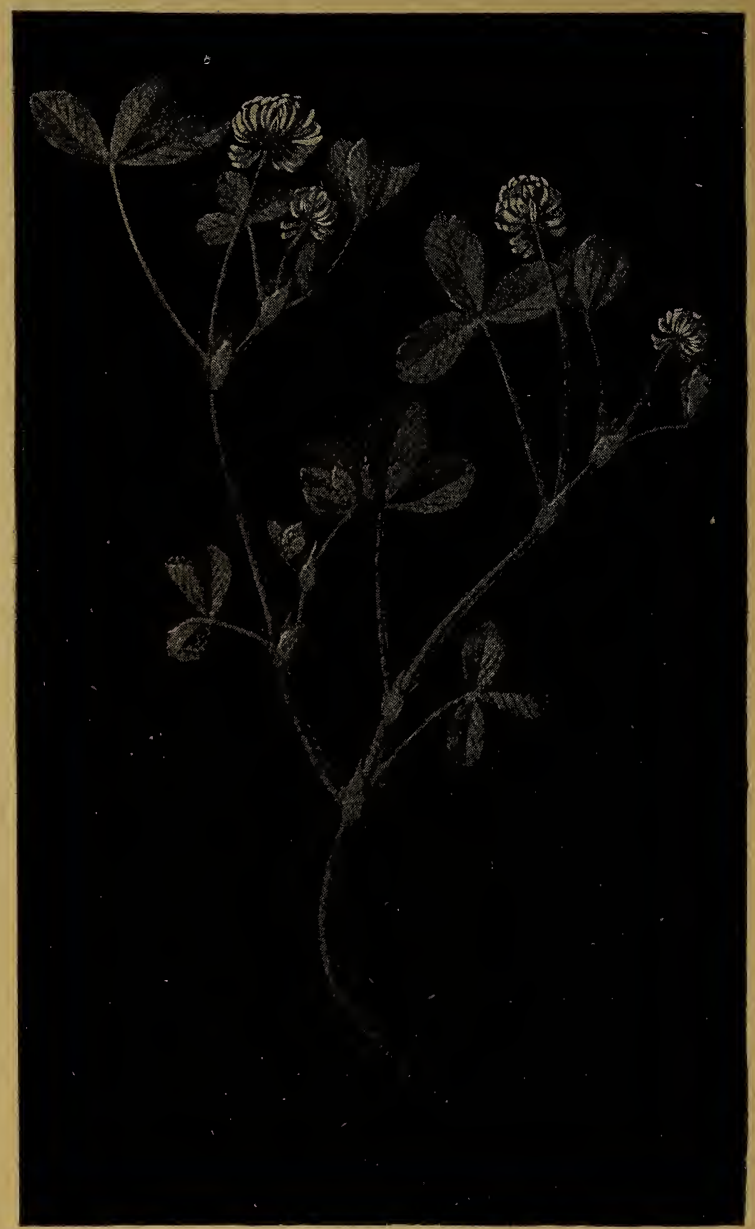

Alsike Clover

10

The Albert Dickinson Co., Chicago-Minneapolis 


\section{Alsike}

(Trifolium hybridum)

Alsike is especially valuable for hay when grown in combination with grasses, or with Red or Mammoth Clover. In general appearance it appears to be an intermediate between White and Red Clover. It is very hardy and may be sown early in the spring but as the seed is small, it should not be covered very deep. On account of its fibrous root it is not so liable to winter kill as Red Clover. Farmers are using Alsike in some sections where Red Clover can no longer be successfully grown.

SolL-Alsike is especially adapted to moist soils, which are too low in humus and lime to grow Red Clover to advantage. Its effect on the soil is nearly the same as that of Red Clover.

SEEDING-If sown alone, it should be sown in the spring with some nurse crop. About 6 to 10 pounds of seed per acre are required. It is well suited for sowing with mixtures of grass seeds, because of its hardihood and perennial habit of growth. In comparison with Red Clover, which lasts only two years, Alsike lasts from three to five, or even longer. It is hardier than either Mammoth or ordinary Red Clover. Like White Clover, Alsike is an excellent honey producer. For pasture purposes, it is commonly sown with some other kinds of grass or Clover, for instance, Timothy, Orchard Grass, Kentucky Blue Grass, or Red Clover. Where hay or pasture is desired, $25 \%$ Alsike Clover, 25\% Timothy, and $50 \%$ Red Clover makes an excellent mixture. For hay, the crop should be harvested when in bloom. Continuous use of pure Alsike Clover, either as a pasture or as a hay, has a tendency to produce sores on both horses and mules.

SEED-Very often seed is taken from the first crop, but an early clipping, especially if the spring is unusually wet, will usually result in a better crop of seed. 


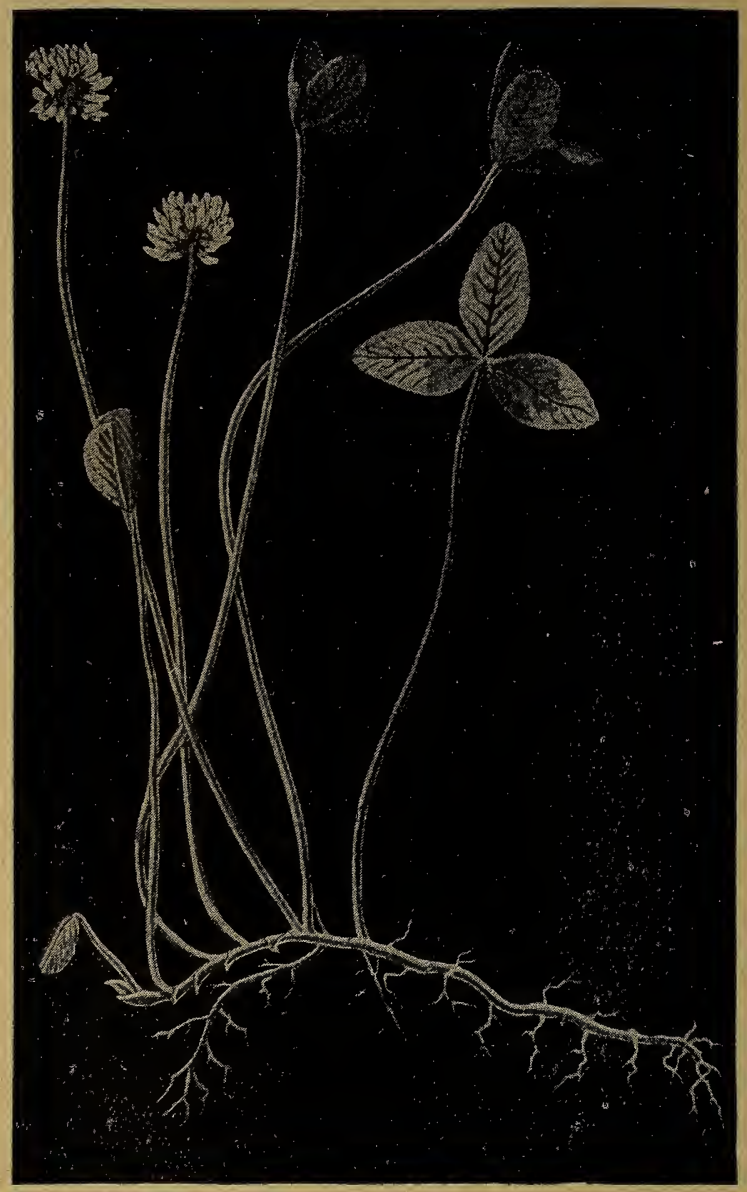

White Clover

The Albert Dickinson Co., Chicago-Minneapolis 


\section{White Glover}

(Trifolium repens)

This hardy species of Clover is a perennial found generally throughout the United States. It is prostrate and creeping in habit, rarely growing more than a foot high. The stems lying on the ground take root freely at the nodes from which may arise independent plants.

SOIL-It will thrive on almost any charac- . ter of soil. A better growth, however, is obtained on a moist well-drained soil, particularly in one with plenty of lime and humus. White Clover responds very readily to the application of wood ashes.

SEEDING AND USES-It is sown at the same time as Red Clover, but rarely alone. In lawn and pasture mixtures White Clover is sown at the rate of 2 to 6 pounds per acre. White Clover has the relation to Kentucky Blue Grass that Red Clover has to Timothy. A small proportion of White Clover in permanent pasture often fills up many a bare spot and produces valuable grazing for all kinds of live stock. It withstands pasturage well and is not apt to cause bloat in cattle as is often the case with Red Clover. It disappears, however, in extremely hot and dry mid-summer, although it withstands drought better than Red Clover, but quickly revives on return of seasonable weather and rain in the early autumn months, and thus furnishes an abundance of fall pasturage. It is also highly prized as a honey plant by bee-keepers.

SEED-The seed crop matures during July and August in the Northern States. Farmers of central and northern Wisconsin practice a two-year rotation in which Barley is harvested the first year and White Clover for seed the second. 


\section{History of Legume Inoculation}

The value of Clover and other legumes as soil-enrichers was recognized by ancient Roman authors who emphasized the use of legumes in regular crop rotations. Many theories were advanced to explain the beneficial action of the legumes. The most plausible one was that the large roots penetrated the lower soil layers and brought plant food to the surface for the next crop. It was not until 1866 when a German scientist, Hellriegel, showed that the successful growth of legume plants made on soils containing no nitrogen depended on nodules, or swellings on their roots, and that legume plants having no nodules would die as soon as the little nitrogen in the seed was exhausted. Still further investigations revealed the presence of bacteria in the nodules. It was then concluded that the peculiar power of legumes to grow on nitrogen-free soils was due to bacteria which enter the root, form nodules, gather nitrogen from the air, and supply it to the plant.

Very often the bacteria necessary to produce nodules are absent from soils. In such cases the legumes draw all their nitrogen from the soil and have no advantages over the more profitable cereal crops. This led to the practice of soil inoculation, or putting into soils the necessary bacteria when they are lacking, and was accomplished by transferring soil known to contain the proper bacteria to the field to be inoculated.

The objections to soil inoculation are many. First it is expensive to ship large quantities of soil over a great distance. Second, there is danger of transferring certain plant diseases as "Leaf Blight" or "Wilt" of Cow Peas which has been known to occur in the South. Third, very objec- 
tionable weeds are easily transferred with the soil.

The modern method of inoculation is with the use of pure cultures. These are usually put up in small bottles which are easily sent by mail. This company has installed a large, well equipped laboratory for the purpose of supplying farmers with cultures which have been carefully tested out. These are very easily applied. The seed is moistened, a little sugar is mixed with the culture, and the mixture is ready to be worked into the moist seed, after which operation seeding can take place. They are sent free with full instructions of how to use them with all our brands of Cow Peas, Soy Beans, or Alfalfa seed. The cultures are branded as "Nod-o-gen" and are mailed direct from the Albert Dickinson Company, at Chicago.

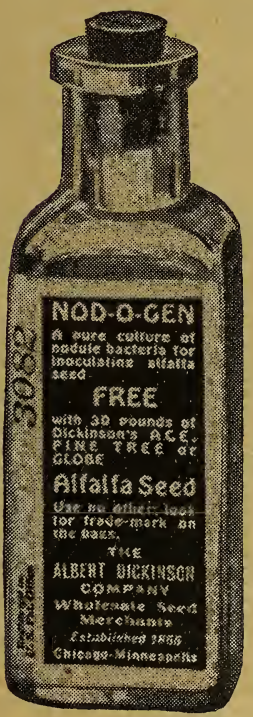

\section{NOD-O-GEN}

Nod-o-gen enriches the soil in nitrogen.

Makes your crops thrive.

Grows more tons per acre.

The increased nitrogen in the crop makes it worth more money per ton.

Makes your farm worth more per acre. 


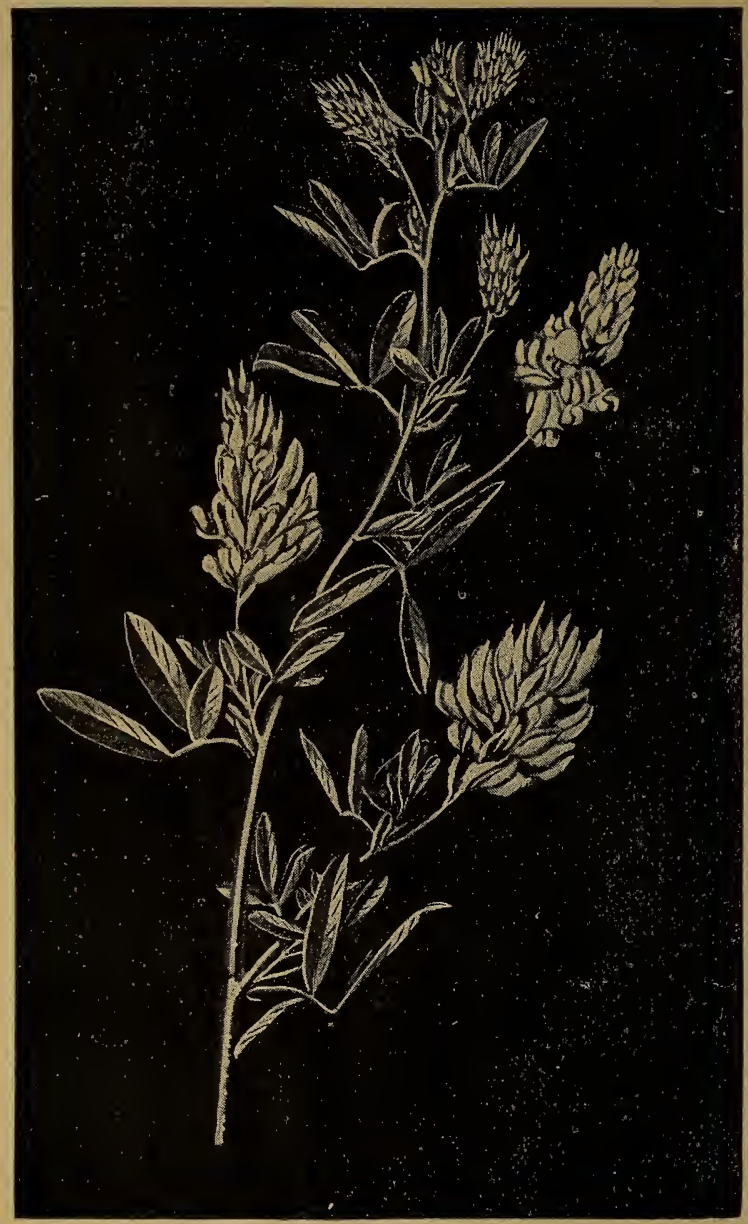

Alfalfa

The Albert Dickinson Co., Chicago-Minneapolis 


\section{Alfalfa}

(Medicago sativa)

It is said that the word "Alfalfa" is of Arabic origin, meaning "the best fodder." The Persians seem to have been the first people to produce Alfalfa. It was introduced into Greece about 490 B. C.; then into Italy and Spain, later into Mexico and South America, and from Chili to California. Alfalfa is the mainstay of the cattle farmer, particularly of the dairyman. No agricultural community can afford to ignore Alfalfa; it is now grown successfully in almost every part of the United States and Canada.

SOIL-A deep, fertile, well-drained soil, rich in lime and reasonably free from weeds, is necessary. The lack of any one of these essentials may be the cause of failure.

THE USE OF LIME-On soils which have a tendency to sourness, the use of lime is beneficial in securing a stand of alfalfa and in some cases is necessary to success. Where lime is necessary it should be applied at the rate of from one to two tons per acre in any convenient form except that from gas works, which contains injurious compounds. Where only a small area is to be limed the ordinary barrel lime allowed to air slake or water slaked to a powder may be used. The ground limestone is the cheapest form where large amounts are to be applied.

BARN-YARD MANURE FOR ALFALFAWell-rotted barn-yard manure is usually a satisfactory fertilizer. Fresh manure generally carries many weed seeds; therefore, if necessary to use it, the application should be made to the preceding crop.

IMPORTANCE OF A WEED-FREE SOIL FOR ALFALFA-The young plants are very tender and apt to be choked out by weeds; it is therefore essential that the land be as free from weeds as possible. This can be brought about by raising some cultivated crop for two or three seasons previous to sowing Alfalfa. 
PREPARING THE SEED-BED-The tender nature of young Alfalfa plants requires that the soil be in excellent tilth at planting time. The seed-bed should be fine on top but thoroughly settled. The young tap root of the Alfalfa plant strikes down im. mediately and is subject to serious injury if it encounters a layer of dry soil at the bottom of the old furrow.

TIME OF SEEDING-The general principle underlying the time of seeding is to sow as far in advance as possible of what promises to be the most trying season for the young plants. Spring seeding is the rule in the irrigated and semi-arid sections of the West. It is also preferable in Minnesota, Wisconsin and the Dakotas, where any but spring or early summer-seeded stands are very liable to winter-kill.

METHODS OF SEEDING-Alfalfa may be planted with a drill or seeded broadcast with a hand seeder, wheelbarrow seeder, or by hand. It is usually better to sow half the seed one way across the field, and the other half at right angles to the line of first sowing.

The average rate of seeding is from fifteen to twenty pounds of good seed per acre.

Covering from three-fourths to one inch deep is usually sufficient on clay soils, or in the semi-arid sections where deep covering is required to insure sufficient moisture for the germination of the seed.

USE OF A NURSE CROP-In the irrigated sections of the West a nurse crop is often used, the two crops being seeded together in the spring. In the states bordering on Lake Michigan a half seeding of Barley is often a success as a nurse crop for Alfalfa, but even in this section it is generally recommended that Alfalfa be seeded alone in midsummer. In all cases the nurse crop, if ever used, should be cut as soon as it shows signs of injuring the Alfalfa plants. 
HARVESTING ALFALFA HAY-The best time to cut Alfalfa is when new shoots are found making their appearance.

It is good practice to start the mower as soon as the dew is off in the morning and prospects for two or three days good weather seem good.

The hay that is cut in the forenoon should be tedded in the swath in the afternoon so that it will dry out underneath. The sidedelivery rake is the ideal machine to turn the hay. The following morning the same rake is used as soon as the dew is off and the hay is sufficiently dry; two swaths are put into one, and by the next afternoon, weather favorable, it is ready to stack or put into the mow. Some growers put it into small cocks (especially if the crop is heavy) and let it stand a few days. When this is done, it is well to provide a canvas cover for each cock. This may seem expensive and tedious, but we must consider that the feeding value of Alfalfa is equal to that of Bran, and that an average crop (five tons per acre) makes land worth, at least, $\$ 1,000$ per acre at five per cent.

Another method of harvesting that is sometimes advantageous if the crop is not too heavy, is to run the mower late in the afternoon, when not much wilting will take place, and when the undergrowth is perfectly dry. This hay is turned the following day just before noon, and will be ready to rake.and stack in the middle of the afternoon; or it may be raked in the afternoon and put in small cocks, turning these over the following day, putting two in one and letting them stand a few days before stacking.

It is very important that Alfalfa be so handled that it will retain its leaves, for these make up 48 per cent of the crop by weight and contain a high per cent of protein.

See page 14 for information regarding culture inoculation of Alfalfa and other legumes. Write for Alfalfa booklet. 


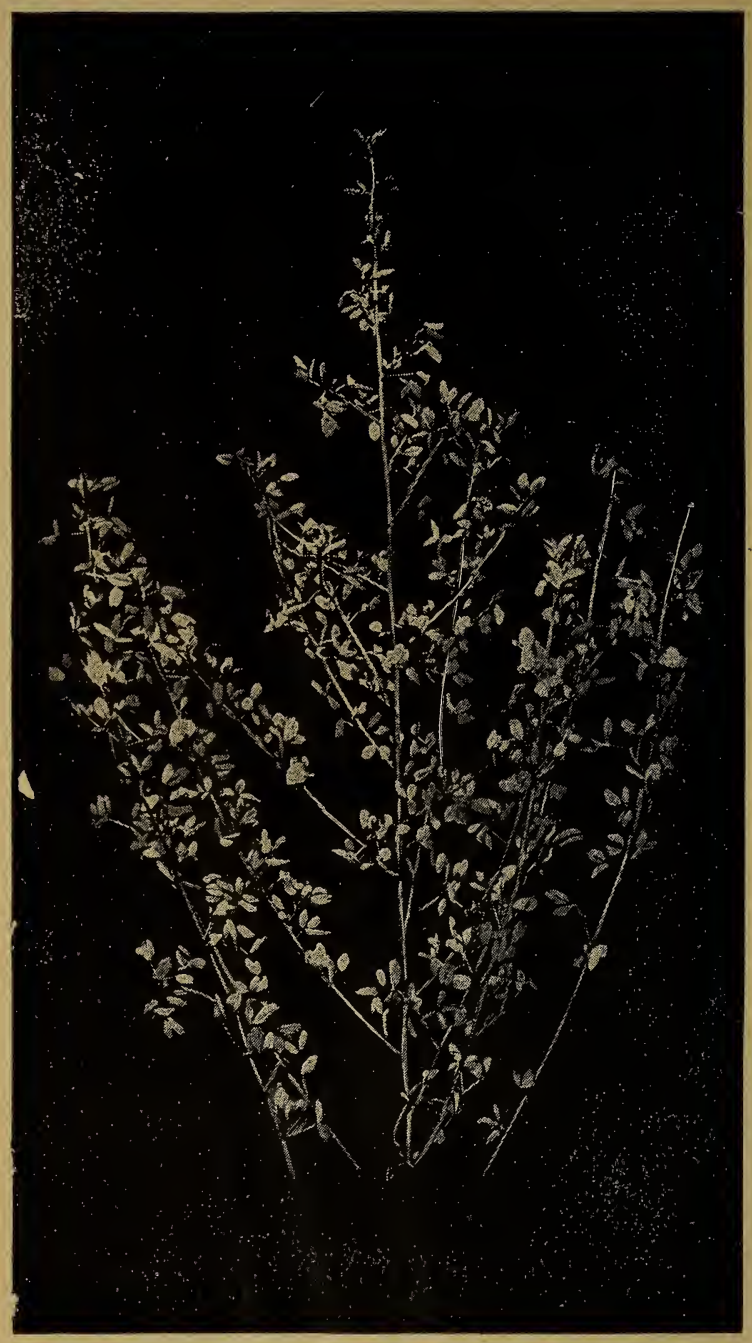

Sweet Clover

The Albert Dickinson Co., Chicago-Minneapolis 


\section{Sweet Clover}

(Melilotus alba)

Sweet Clover grows in all parts of the United States and Canada. Experience has proved that, in many sections, it is a valuable addition to farm crops.

SOIL REQUIREMENTS-Sweet Clover thrives on poor clay as well as on poor sandy soils, but it prefers soils of limestone origin; if seeded on clay soils which are inclined to be sour, considerable lime should be added at seeding time.

PREPARATION OF SEED-BED-The seed-bed must be well prepared and very firm. The lack of a firm seed-bed is often the reason why Sweet Clover fails on cultivated fields. It is usually best to seed on ground such as Corn stubble that does not require ploughing, depending upon a disk or spike-tooth harrow to cover the seed.

SEEDING-It is seeded either in spring or fall, depending upon the climate. Many methods of seeding are practiced, but when sown alone the best results are obtained. Sometimes good stands are obtained with a nurse crop. Twenty to thirty pounds of hulled seed and at least twenty-five to thirty-five pounds of unhulled seed are usually sown per acre.

USES-It is the most vigorous soil enricher of all the Clovers, and will usually make satisfactory growth on poor, worn-out soil which will not support ordinary farm crops.

As was the case with some other legumes when first introduced (including Alfalfa and Cow Peas), some difficulty is experienced in inducing stock to become accustomed to eating it.

ERADICATION-Sweet Clover can usually be killed when mown in full bloom. It disappears completely under ordinary mowings or cultivation; for under such conditions it lasts only two years and cannot reseed itself.

See page 14 for information regarding inoculation of Sweet Clover and other legumes. 


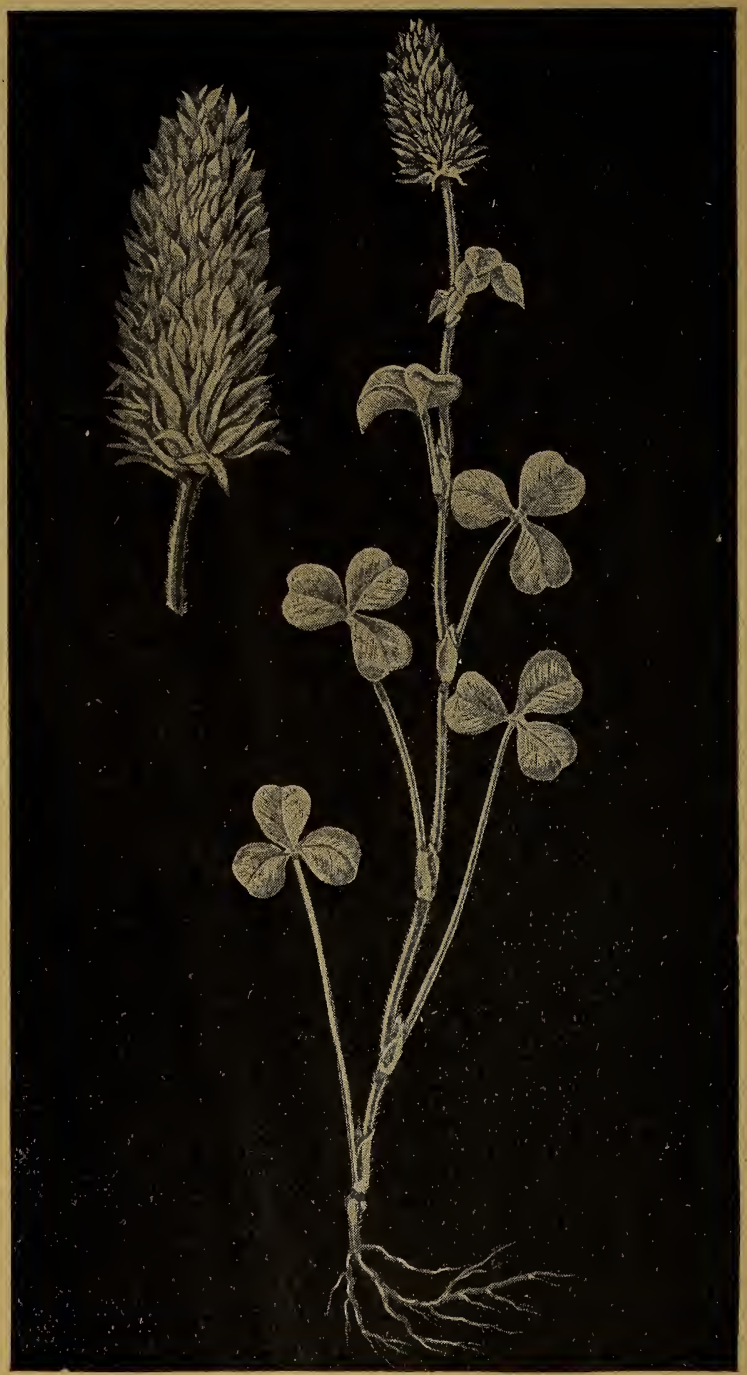

Crimson Clover

The Albert Dickinson Co, Chicago-Minneapolis 


\section{Crimson Clover}

(Trifolium incarnatum)

Crimson Clover grows well in a moist, mild climate. It will not stand hard freezing, and, for this reason, should not be sown as a winter crop outside Middle Atlantic and Gulf States. In the colder sections it is sometimes used with fair success as a summer cover crop for orchards.

SOIL-It thrives best on rich, rather sandy loams; but it gives good results on light sandy soils well as on clay soils, if they are not too stiff and cold.

SEEDING-Throughout the Middle Atlantic States and South generally, Crimson Clover may be sown any time from July 15 th to September 15th, and if the moisture conditions are favorable, it may be sown still later in the Gulf States. As a rule, the best results are obtained from seed sown in July and August. In the North, spring sowing is necessary. Sow twelve to fifteen pounds per acre.

HARVESTING-Crimson Clover may be harvested in the same way as common Red Clover. The crop should be cut for hay at or before full bloom.

USES-Crimson Clover hay has a feeding value equal, if not superior, to that of Red Clover or Alsike. This clover begins growing very early in the spring, producing a good growth when most other crops are just starting. This makes it a desirable crop for early pasturing and soiling. However, its chief value is as a soil renovator. A common practice in the South is to sow the seed early in the fall and plow the crop under two weeks before bloom. By this method large quantities of humus and as much as 200 pounds of nitrogen are added to the soil before the regular crop is sown. It is also highly valued as' a Clover crop for orchards as it reduces the moisture of the soil, thus hastening the maturity of the wood before freezing, and retains much of the plant food for the trees which would otherwise leach out of the ground. 


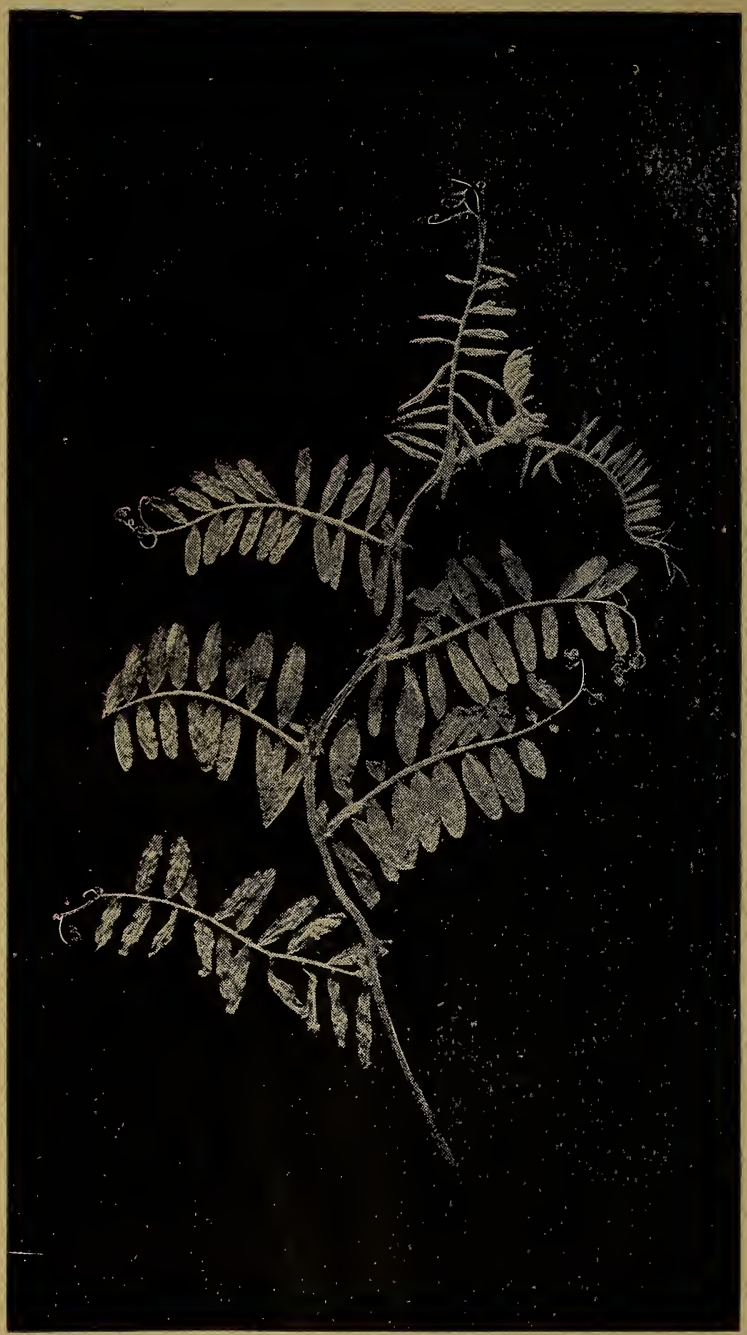

\section{Hairy Veteh}

\section{4}

The Albert Dickinson Co., Chicago-Minneapolis 


\section{Hairy Vetch \\ (Vicia villosa)}

Sometimes called Winter or Sand Vetch. This is one of the best annuals grown for stock feed, soil improving purposes, and as a cover crop in orchards. If used as a soiling crop, an acre of Vetches seeded with Oats, Rye or Winter Wheat, will yield six to eight tons of green fodder, which is readily eaten by all kinds of stock.

solL-It will grow in almost any welldrained soil, and is especially suitable for sandy soil. The seed-bed should be clean, firm, moist and well-pulverized.

SEEDING-Hairy Vetch is usually sown from about the middle of August to the first of October; or in the spring from the latter part of April to the middle of May. It may be sown broadcast or with a grain drill at the rate of one to one and one-half bushels of seed per acre. Less seed will be required if drilled. The seed should be covered about the same depth as grains.

A bushel of Rye, Wheat or Oats per acre is usually sown with one bushel of Vetch, so as to furnish a support to keep the vines off the ground. The vines are very difficult to cut when sown alone.

WHEN TO CUT-Vetch should be cut for hay when the pods are half formed. It may be cut for green feed at the time it is in full bloom.

USING THE CROP-If cured properly it makes good hay, as the feeding value of Vetch is similar to Clover. It also is very well adapted for pasturage purposes, as it will produce forage very late in the fall and early in the spring, at the two periods when it is most needed. It is also a good crop to plough under for green manure. Sometimes it is used for ensilage, in alternate layers with green Corn. As it lives over winter, it is one of the leading cover crops recommended for orchards.

See page 14 for information regarding artificial culture inoculation of Hairy Vetch. 


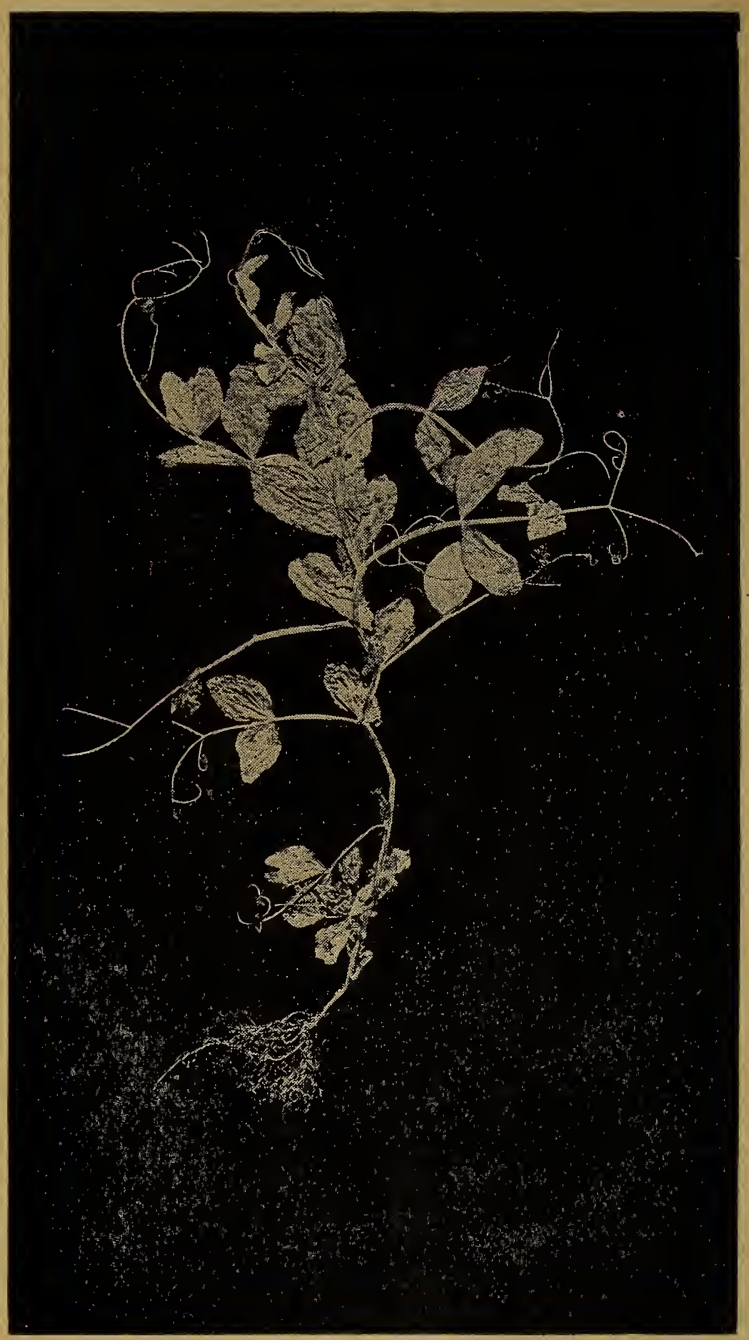

Field Peas

The Albert Dickinson Co., Chicago-Minneapolis 


\section{Field Peas}

(Pisum arvense)

FIELD PEAS are cultivated most successfully in Northern latitudes, and high altitudes, as cool temperatures are most desirable for their growth.

SOILS-Peas do well on a large variety of soils, but clay loams with a good sup. ply of lime produce the heaviest growth and yield. Light leachy sand soils are not suitable for the full development of the vines, because of lack of moisture, while on muck lands, if not too wet, too rank a growth of vine is obtained.

SEEDING-Peas are vigorous hardy growers and make the best growth during the moist cool season of the year. The soil should be, preferably, plowed in the fall, disked well in the spring and the seed sown as early as soil and weather conditions shall permit, either in drills or broadcast, at a depth varying from 2 to 4 inches. The rate of seeding is from 2 to 3 bushels per acre when sown alone. When sown with Oats, which is a very popular practice for soiling purposes, $1 \frac{1}{2}$ to $13 / 4$ bushels of Peas and 1 to $1 \frac{1 / 4}{4}$ bushels of Oats are required per acre. Average yields of such a mixture vary from 10 to 20 tons per acre.

HARVESTING-The grain is harvested when about two-thirds of the pods have turned yellow. As shattering of pods takes place readily, the use of a pea harvester (a device attached to the ordinary mower) will prevent heavy losses, and facilitate the cutting. Yields per acre vary from 16 to. 40 bushels, depending on soil and climatic conditions.

USES-Both grain and straw are exceptionally high in feeding value being rich in muscle, blood, and bone making constituents. They are unexcelled as a sole ration fed to swine during the fattening period, producing better gains, pound for 
pound, and a better quality of pork than can be obtained with Corn. Peas fed in the proportion of $1 / 3$ to $1 / 2$ with Wheat bran, shorts, or ground Oats form an excellent ration for ewes in milk, brood sows, milch cows, lambs, colts and horses at work. Peas cut for hay while the vines are still a little green and properly cured, rank next to Clover hay in feeding value. Aside from the feeding value, they rank next to Red Clover as a soil improver.

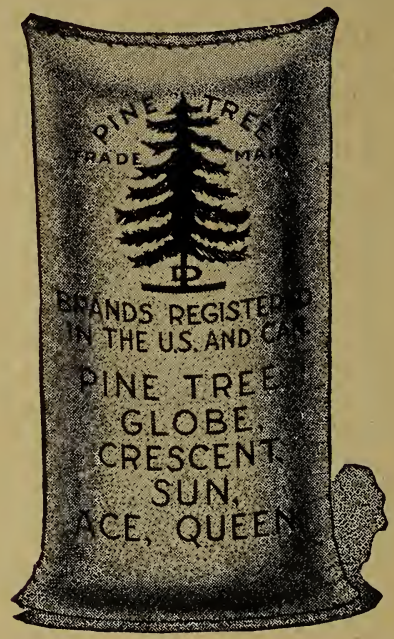




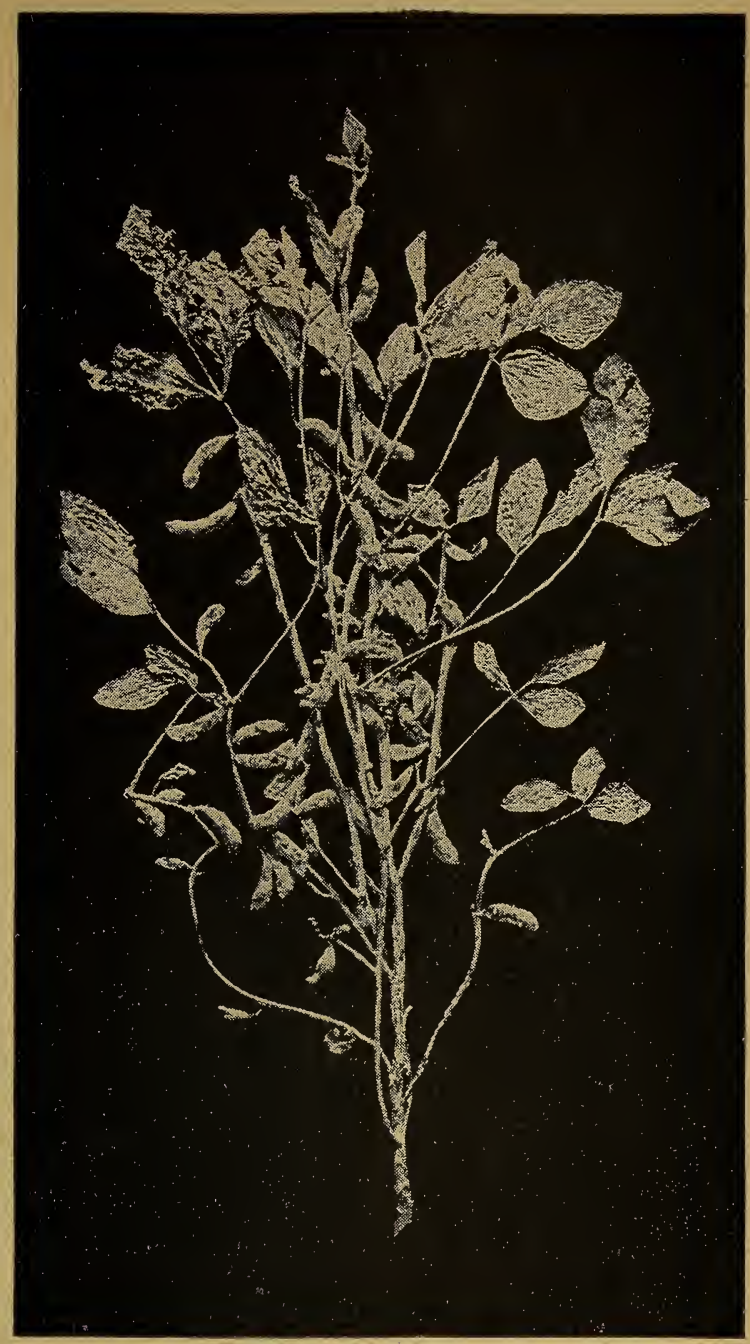

\section{Soy Beans}

The Albert Dickinson Co., Chicago-Minneapolis 


\section{Soy Beans}

(Glycine hispida)

Results of tests by State Agricultural Experiment Stations during the past few years have shown that Soy Beans may be grown over a much wider area than was originally thought profitable. Generally speaking, the Soy Bean requires about the same temperature as Corn. The mammoth or late maturing varieties are adapted only to Southern conditions, while the varieties producing medium size plants, which will mature in from ninety to one hundred days, will mature as far north as Northern Wisconsin.

SOIL-The soil requirements are much the same as those of Corn. They will make a satisfactory growth on poorer soil than Corn, provided inoculation is present, but will not make nearly as good growth on poor soil as Cow Peas. A well-drained soil is not required for their best development, although they will not grow in soil where water stands for any considerable length of time.

SEEDING-Good preparation of the soil is necessary; otherwise weeds are likely to choke out the young plants. Under nearly all conditions the crop should be grown in rows and given sufficient cultivation to keep down the weeds. The planting should be shallow, preferably from one to two inches in depth. There should be a plant on an average of every two or three inches in the row, and the rows twenty to thirtysix inches apart to allow cultivation. A bushel of good seed is sufficient to plant two or three acres, if in cultivated rows, but hardly enough for one acre if sown broadcast. Date of planting usually about June 1st, but they may be planted from early spring to midsummer.

HARVESTING-To make good Soy Bean hay, the crop should be cut when about half the pods are full grown or when the 
top leaves begin to turn yellow. Allow same to lie in swath until the leaves are well wilted, but not dry and brittle. After raking into windrows they should be left for a day or two, depending on the weather, and then put in small cocks or bunches. Prevent loss of leaves, as these are the most valuable part of the plant except pods. The average yield is about two tons of cured hay per acre.

USES-The seed of the Soy Bean is very rich in protein and oil, but contains no starch; as a feed it occupies the same place as cottonseed meal and oil meal. These high protein concentrates are necessary in all successful stock feeding, especially so in milk production and in the feeding of immature animals. Growing the Soy Bean will enable the farmer and feeder to produce at least part of the required quantity at a moderate cost. Soy Bean hay is practically identical in feeding value with $\mathrm{Al}$ falfa.

FEEDING VALUE-GREEN-As a soiling crop for cows, there is nothing better to produce a high yield of milk. Hogs turned into a patch of Soy Beans, just as the beans are beginning to form, will make a good growth without any grain to speak of. As a green manure crop to plough under to increase the fertility of the soil, Soy Beans give good satisfaction, for, under most conditions, they produce a good growth in a relatively short time.

They are also a valuable addition to Corn for silage purposes, tending to make sưch silage a more nearly balanced ration. They can be well used for that purpose in the proportion of one part Soy Beans to four or five of Corn.

If grown for seed alone, the harvesting can be done most easily by waiting until all the leaves have fallen. From twenty to thirty bushels of grain and one and one-half to two tons of straw per acre are not uncommon yields.

See page 14 for information regarding artificial culture inoculation of Soy Beans. 


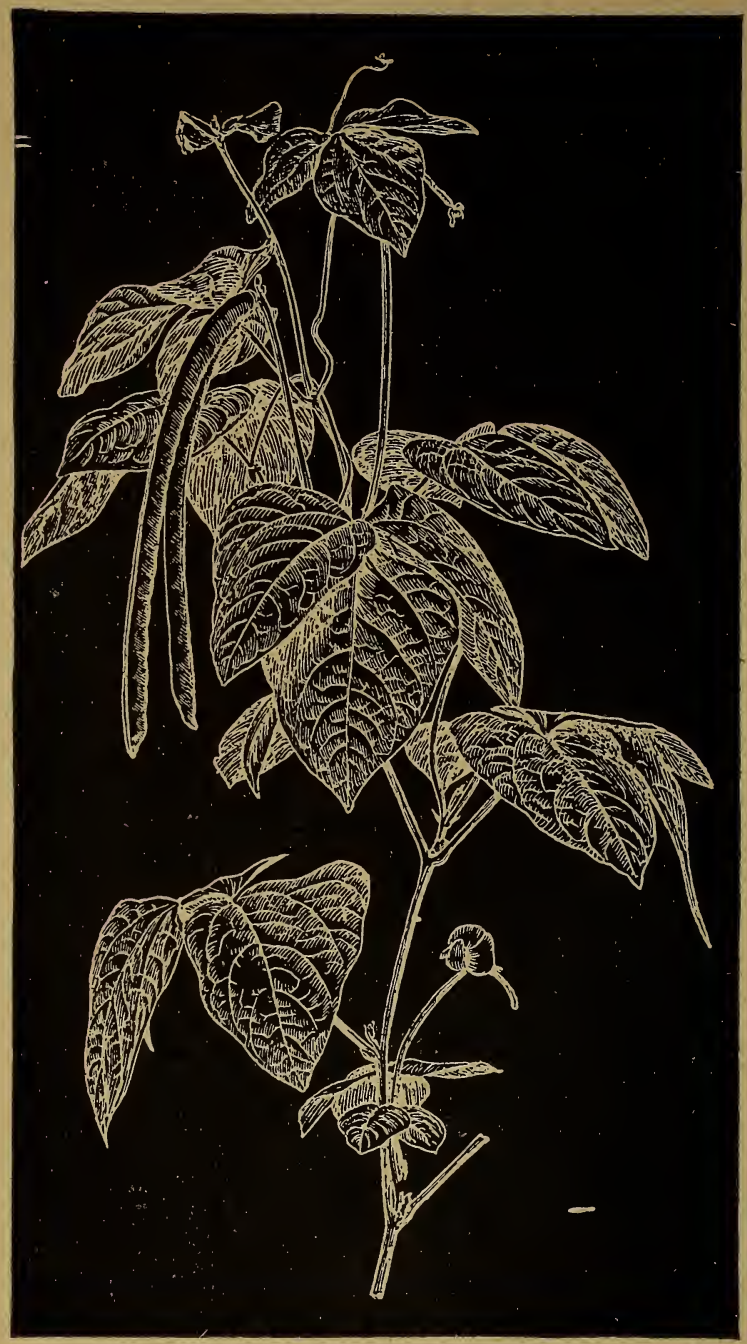

Cow Peas

The Albert Dickinson Co., Chicago-Minneapolis 


\section{Cow Peas}

(Vigna sinensis)

The Cow Pea ranks along with Clover as one of our greatest soil improvers. For many years, it has been extensively cult1vated in the Southern States, but its range has gradually extended northward until it is being successfully grown in many parts of Massachusetts, New York, Ohio, Indiana, Illinois and Minnesota.

\section{VARIETIES.}

WHIP-POOR-WILL-The Whip-Poor-Will is considered the standard of all field Cow Peas. It is suitable for either grain or hay production or both. The fact that it can be handled by machinery is bringing it more and more into prominence.

NEW ERA-The New Era usually produces a heavy crop of seed and matures in from seventy-five to ninety days. It is one of the earliest of the Cow Peas and is the most easily handled by machinery.

See Farmers' Bulletin 318.

MIXED COW PEAS-A large percentage of the Cow Pea crop comes to market under the name Mixed, being composed of different varieties which have grown together. They make a heavy growth of vines and are splendidly adapted for ploughing under for soil improvement.

Select varieties suitable to your locality. Early maturing varieties should be planted in the North.

SOILS-One of the strong points of the Cow Pea is its ability to grow on poor soils. The roots will go down into the subsoil and gather food to sustain growth in soils where other legumes, such as Clover and Alfalfa, would die. It will grow better, however, on rich soil, but over-rich soils will produce an excess of vine in proportion to seed they bear. A sandy loam is considered best for seed production. 
SEEDING-When grown for hay production, Cow Peas may be broadcasted, or put in with a grain drill. If broadcasted, one or two bushels per acre is required; if put in with a grain drill, which gives the most general satisfaction, use three to five pecks to the acre. If grown for seed and hay production, they should be planted in rows twenty-four to thirty-six inches apart, and cultivated two or three times. A grain drill may be used in planting in rows, by closing part of the tubes.

The land should be ploughed and well harrowed. As the Cow Pea is a tender annual, it will not grow until weather and soil become warm and settled. About the latest date for planting corn is a safe rule to follow.

HARVESTING-The proper time to cut Cow Peas for hay is when most of the pods are full grown, and a considerable number of them ripe. If cut at the right stage of maturity, four to five days of dry; sunny weather will cure them into hay of excellent quality.

COW PEA HAY - This is very nutritious; it is nearly equal to Wheat bran as part of a ration; it is satisfactory for work stock and for beef or milk production, and gives good results when fed to poultry.

Cow Pea straw is an excellent roughage and nearly as valuable as timothy hay.

See page 14 for information regarding artificial culture inoculation of Cow Peas and other legumes.

\section{You get what you pay for when you buy Dickinson's "Pine Tree."}




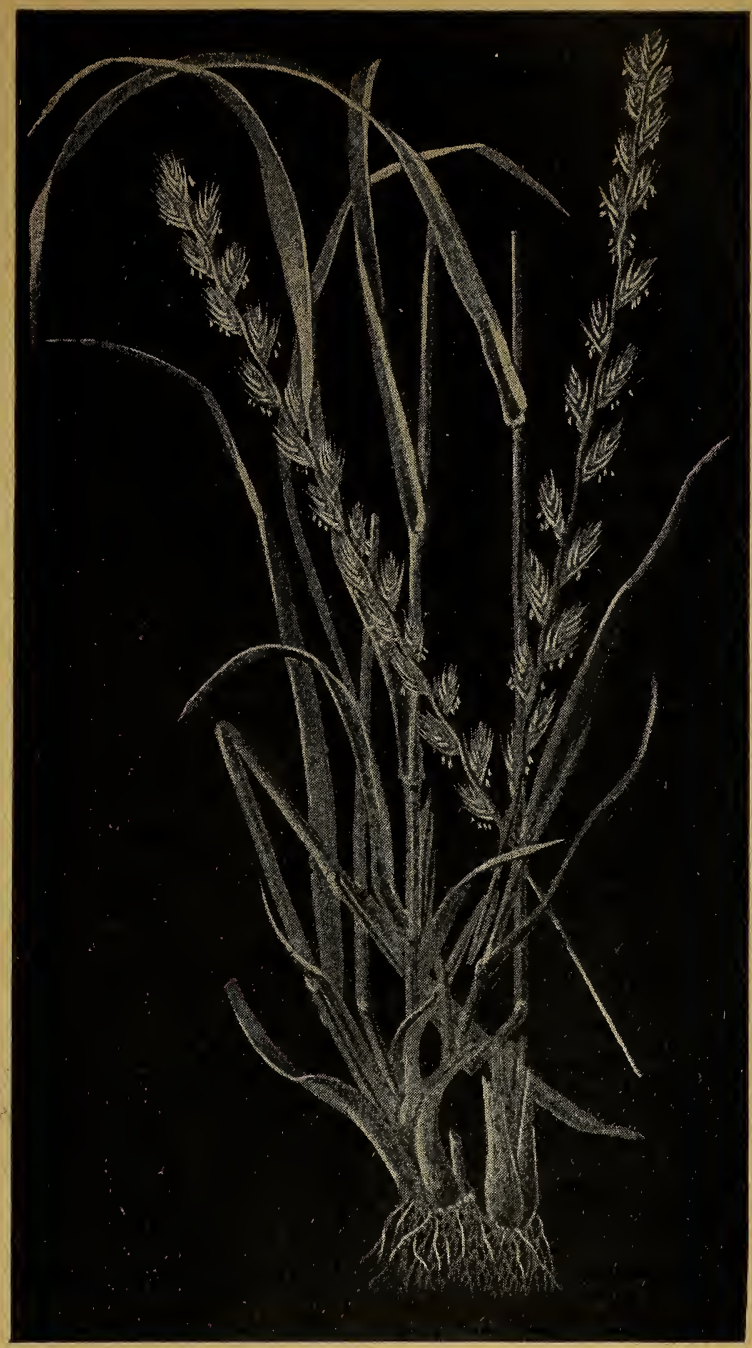

Italian Rye Grass

The Albert Dickinson Co., Chicago-Minneapolis 


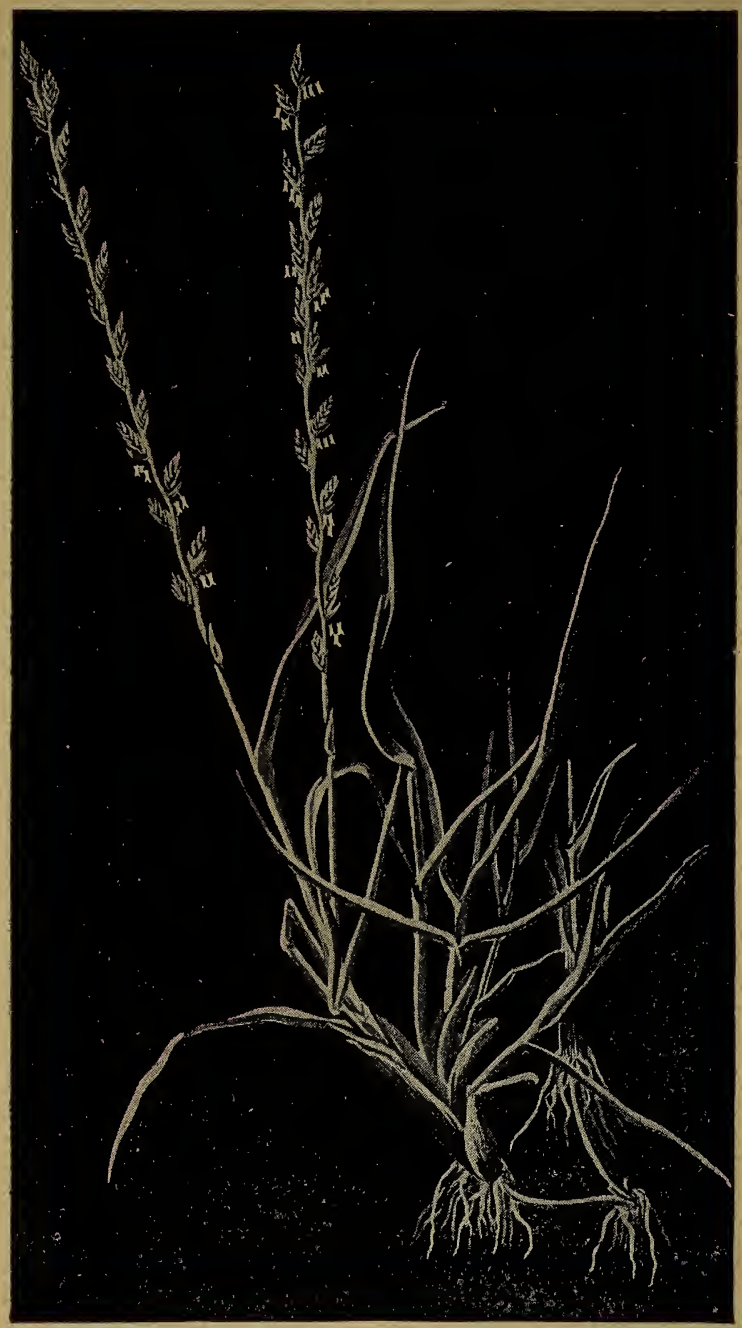

Perennial Rye Grass

The Albert Dickinson Co., Chicago-Minneapolis 


\section{Rye Grasses}

(Lolium italicum and perenne)

The two common varieties of Rye Grasses are the Italian Rye (Lolium italicum) and Perennial Rye (Lolium perenne). Both of these grasses are of European origin, and, while very popular there, they are of minor importance in this country, except for a few localities. Soils most suitable for their growth are moist, loamy soils of a limestone origin. They do not do well on stiff clays nor will they withstand much drought. They are very easily established, and relished by cattle, but are rather short lived. The Italian Rye Grass lasts only two years and often only one, while Perennial Rye lasts from two to five years. The usual amount of seed to sow per acre varies from 30 to 40 pounds.

In this country Italian Rye Grass thrives best in our eastern states, in a region between Pennsylvania and Virginia. It grows somewhat taller and more rapidly than Perennial Rye Grass. It also produces a larger amount of foliage which is coarser, grows more upright, and is of a lighter green color. It may also be distinguished from the other variety by the short awns on the seeds. Because of its short duration it is not valuable for permanent meadows. It is advisable to mix it with some other standard grasses like Red Top or Orchard which will increase in value while the Rye Grass decreases.

Of the Perennial Rye Grass variety limited quantities are grown in the United States west of the Cascade Mountains on the Pacific Coast. It is a valuable grass in lawn mixtures because of its rapid growth of fine leaved foliage. Although used for both hay and pasture, it is best adapted to pastures of short duration. European countries recommend sowing it in mixtures with other grasses, not to exceed $10 \%$ of the whole. Yields of hay vary from two to two and one-half tons per acre. Both grasses produce seed abundantly often yielding 40 bushels to the acre. 


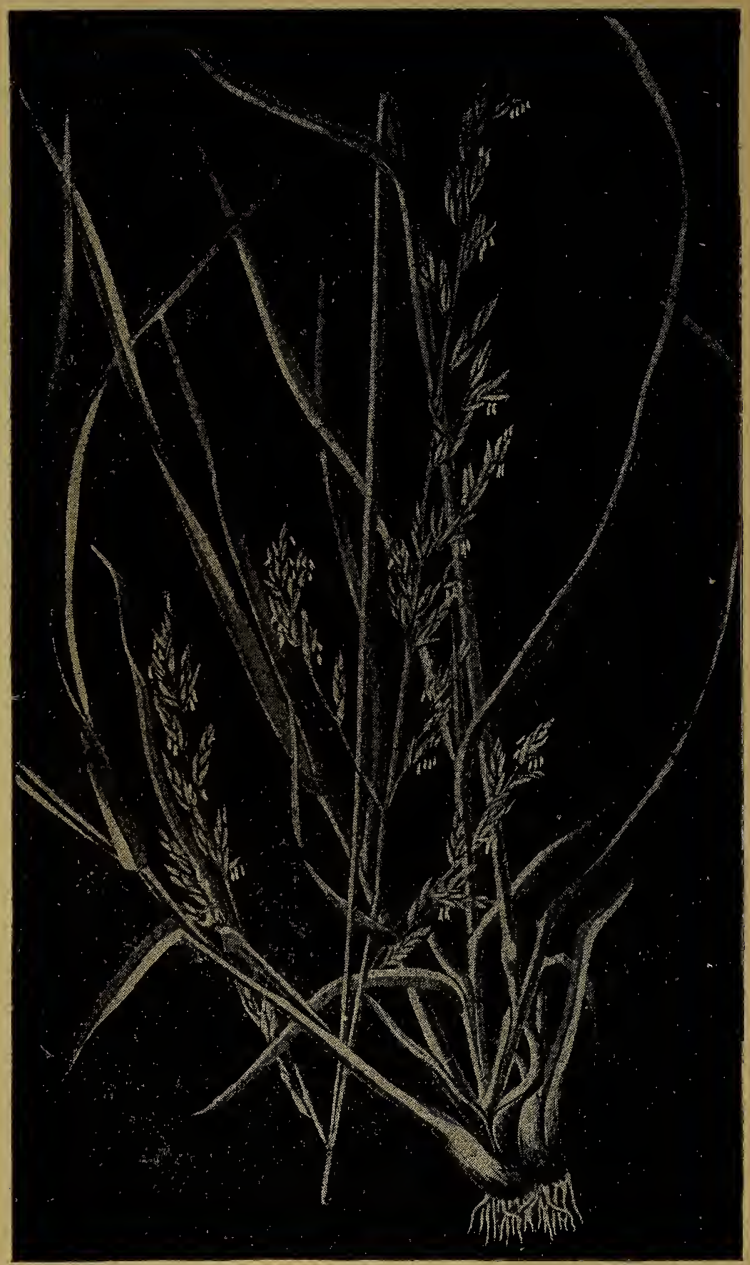

Mcadow Fescue 


\section{Meadow Fescue}

(Festuca elatior)

MEADOW FESCUE - Or English Blue Grass, as it is sometimes called, is a valuable hay and pasture grass. In nearly all the Northern States and in Canada, where more recently grown, it is coming into special favor. It may often be used to advan. tage in permanent pasture and meadow mixtures. It is a very valuable grass to sow on wet or moist lands, as it grows very rapidly and tends to keep down the coarser grasses which naturally grow in such places. It will thrive in wet places when trampled by stock, where Timothy, Kentucky Blue Grass or Clover would fail. It is particularly adapted to clay and other heavy soils.

SEEDING-Meadow Fescue is .usually sown in the fall, from about August 15th to September 15th, without a nurse crop. It may also be seeded in the spring. The seed-bed is generally prepared by discing a corn fleld or ploughing under grain stubble. A finely pulverized, firm seed-bed is necessary for the proper germination of this, as well as other kinds of grass. The seed may be sown broadcast and covered with a harrow, as other grass and Clover seeds usually are, but the general opinion is that a press or disk drill, covering just a trifle more lightly than in sowing grain, gives better results. Fifteen to twenty pounds of seed per acre is recommended.

HARVESTING-When used for hay it is cut as it comes into bloom about June 20th to $25 \mathrm{th}$, and usually yields one to one and one-half tons per acre. On exceptionally good soil, by application of manure, this yield may be increased to two and even three tons per acre.

Meadow Fescue produces a good quality of hay which is readily eaten by all kinds of stock. Generally speaking, it does not yield so much hay as Timothy, but when established the meadow will live longer. We recommend this for a hay crop where Timothy does not do well. 


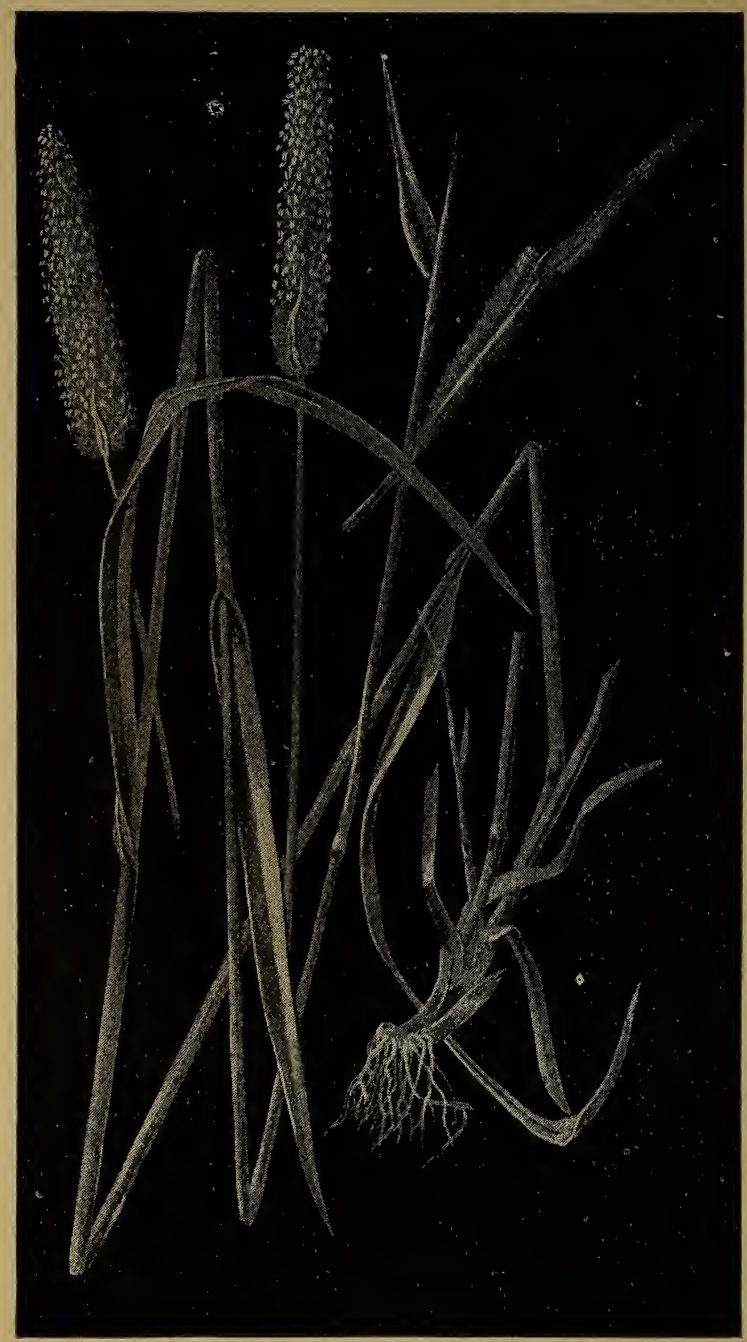

Timothy

40

The Albert Dickinson Co., Chicago-Minneapolis 


\section{Timothy}

(Phleum pratense)

Timothy is the standard hay of commerce. The cheapness of the seed, the ease of culture, and excellent quality of the hay make it a favorite.

TIMOTHY is also known as Herd's grass and meadow cat's tail. The names Timothy and Herd's grass originated after men credited with having introduced this forage into certain sections of this country. Timothy Hanson or Hanso, of Maryland, introduced the seed from England in 1720 and distributed it through Virginia and Carolina. John Herd is said to have found it in a swamp in New England about 1700 and began to cultivate it and later distribute it through New England. Meadow cat's tail, the oldest name, was given to this grass because of the appearance of the head.

SoIL-It is adapted to all soils, but succeeds best on moist loams and clays. The life of a Timothy meadow varies according to soil and climate. It produces more profitable yields the first and second years.

SEEDING-Timothy is grown in a four or five-year rotation; fifteen pounds of Timothy is considered a full seeding when used alone; when seeded with Clover, Wheat, Oats or Barley, eight to twelve pounds of Timothy with four to five pounds of Red Clover is a desirable mixture.

HARVESTING-It is preferable to cut Timothy after the seed is formed and in full milk on account of the roots being better able to withstand drought. It should be cut four inches from the ground, as most Timothy is killed by mowing close and early, before it has come to maturity. 


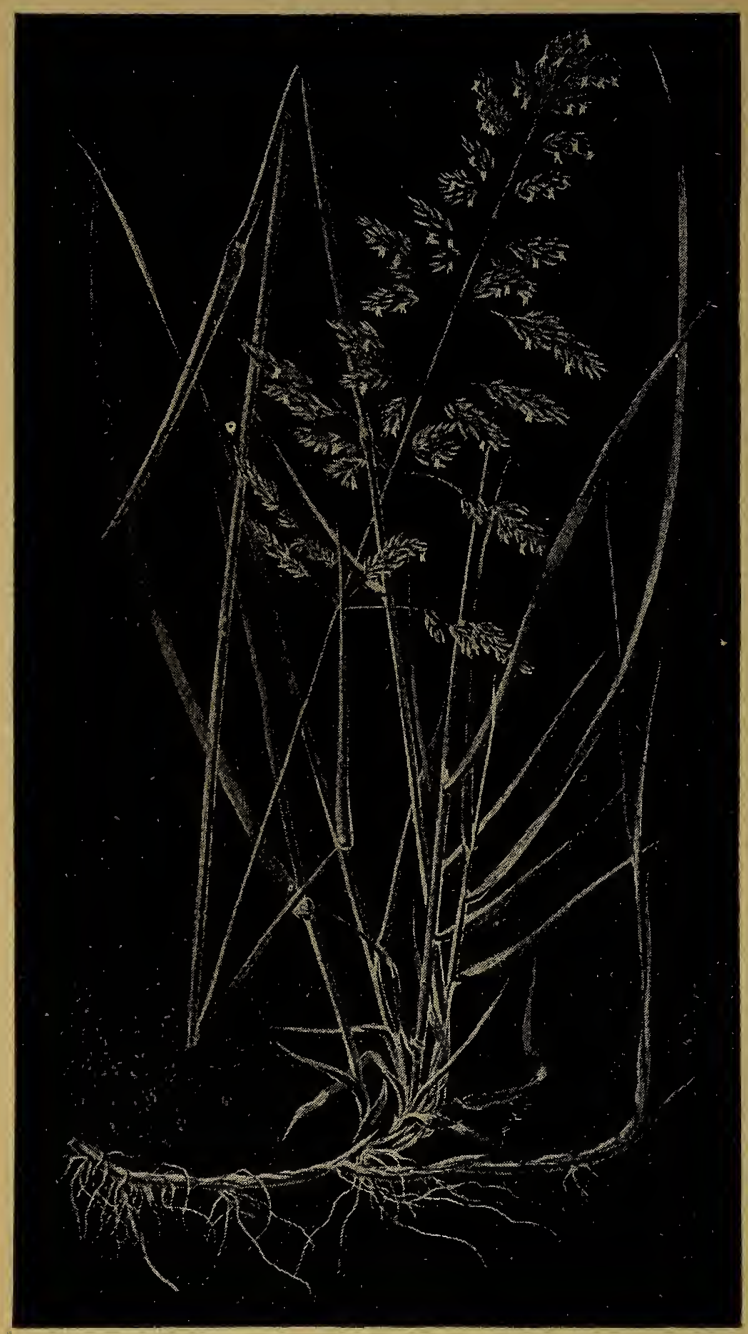

Kentucky Blue Grass

The Albert Dickinson Co., Chicago-Minneapolis 


\section{Kentucky Blue Grass \\ (Poa pratensis)}

Kentucky Blue Grass is the "King of Grasses." As a pasture grass it is without a rival. To the stock farmer it is his leading asset; once established, a Blue Grass pasture is a source of permanent income. Its only enemy is the burning rays of $\mathrm{Au}$ gust sun, but with the returning cooler days and autumn rains it quickly restores its vigorous aftermath which remains abundant until checked by settled winter weather.

SOIL-It requires a good soil, containing some lime, in order to yield profitable crops, or produce good lawns.

SEEDING-The main point is to sow early enough in the spring so that the grass will get a sufficient hold to resist the heat and drought of summer; or, if sown in the fall, the seeding should be in the latter part of August or early in September. If sown at that time, the fall rains will cause the seed to germinate quickly and grass to grow rapidly; if sown much later it is liable to be killed by frost. If sown alone, 15 to $20 \mathrm{lbs}$. of good seed should be sown per acre. When used for lawns, sow at the rate of three bushels per aere.

Kentucky Blue Grass may be sown with Rye, Wheat or Barley; the grain should be sown first, the land harrowed and, if possible, rolled. After this the grass seed may be sown and covered very lightly; it will grow without covering, but light covering is advisable.

HARVESTING-Kentucky Blue Grass blooms in the latter part of May and is ready to harvest about June 1st. It is one of the easiest grasses to cure.

USES-It is used mainly for lawn and pasture purposes. If intended for permanent pasture, it should not be grazed very closely for the first two years, or until it becomes well established.

Owing to its perennial habit and thick growth of sod, it is particularly suited for lawns or for turfing the slopes of terraces and embankments where the soil is good. 


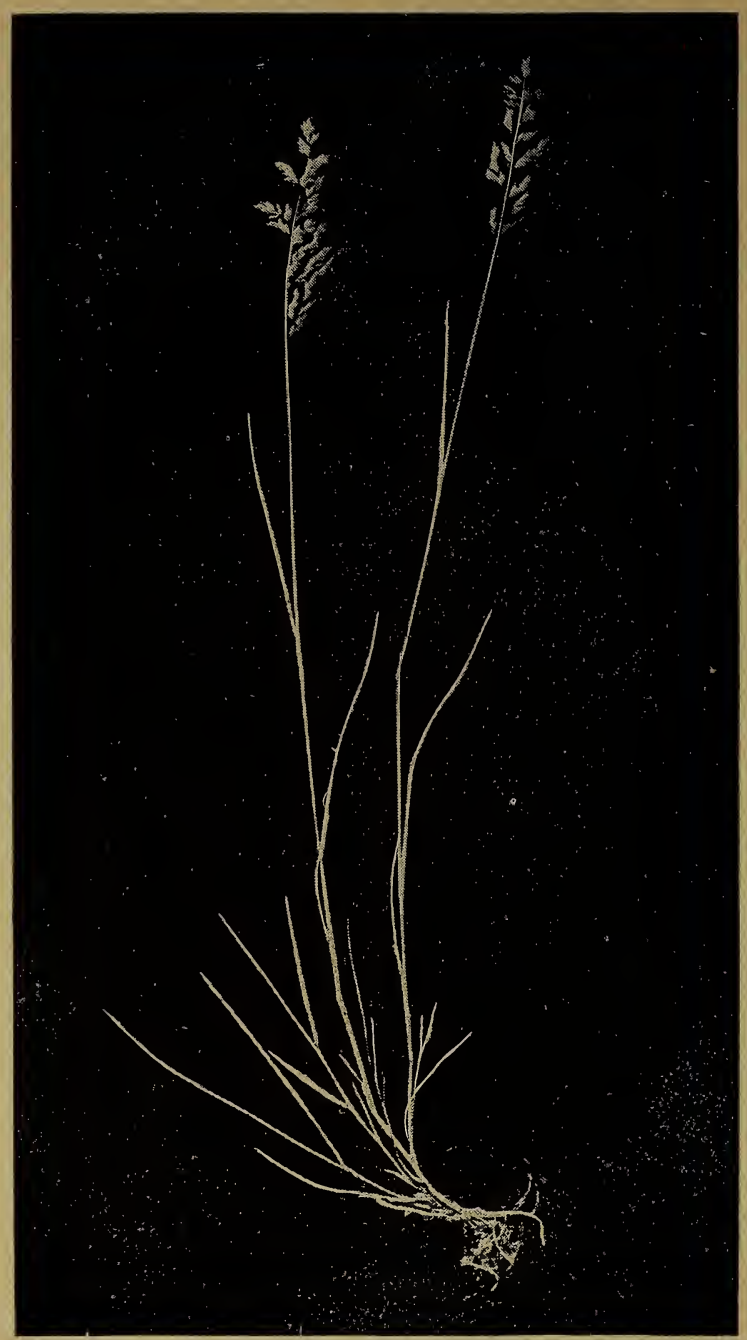

Canada Blue Grass

The :-lbert Dickinson Co., Chicago-Minneapolis 


\section{Canada Blue Grass}

(Poa compressa)

Canada Blue Grass, also called Virginia Blue Grass or wire grass closely resembles Kentucky Blue Grass. The stems are flat, almost solid, rather hard, and bluish green in color; whereas, the Kentucky Blue Grass grows taller and has round and weaker stems of a more greenish color.

SOILS-It likes soils composed chiefly of clay, particularly stiff clay soils of low fertility. On gravelly clay soils it does well, but on sandy soils it is seldom found in quantity. Soils too low in fertility and lime to grow Kentucky Blue Grass may yield a fine crop of Canada Blue Grass. It is more advisable to sow Red Top and Orchard Grass with it on such soils.

SEEDING-Sow in the early spring on Wheat, or with grain in the fall, at the rate of 15 lbs. per acre, for, although the grass volunteers readily in Wheat fields, the addition of seed practically insures a perfect stand the first year following the Wheat crop. This practice applies to sections where the grass occurs commonly. In sections where it does not grow naturally in abundance, $20 \mathrm{lbs}$. or more per acre are recommended.

USES-Canada Blue Grass is of value chiefly as a pasture grass, making good grazing of nutritive value for stock, especially beef and dairy cattle. The quality of the hay produced is very good, being highly prized by horsemen, but the yield is not sufficiently high to make it of much value for this purpose. When used for either lawns or golf links, Canada Blue Grass should be kept very closely clipped, for otherwise it becomes very wiry and makes a turf of poor texture.

DISTRIBUTION-Canada Blue Grass has the same general distribution as Kentucky Blue Grass, but it is not so abundant. It can doubtless be used farther south than Kentucky Blue Grass, because of its superior resistance to drought and extended periods of hot weather. 


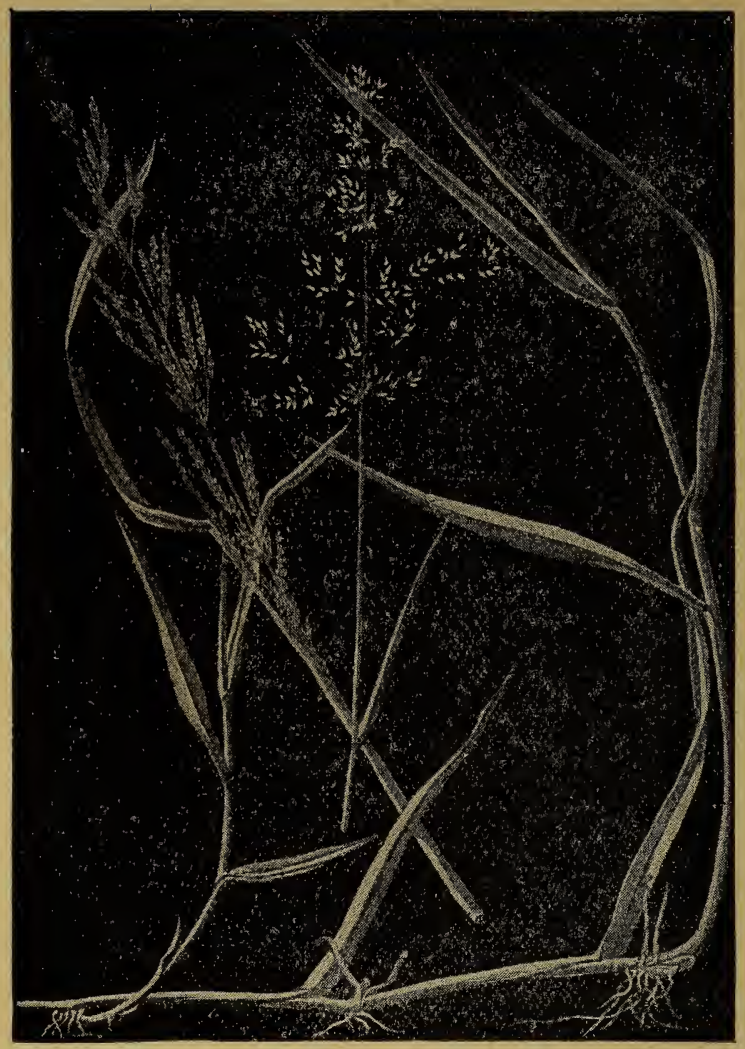

\section{Red Top}

The Albert Dickinson Co., Chicago-Minneapolis 


\section{Red Top}

(Agrostis alba)

Red Top is highly thought of, both as a permanent pasture and as a meadow grass for hay. It thrives under a wider range of soil and climate than any other cultivated grass. Plants grow from 1 to 3 feet high, are strongly stoloniferous, especially upon moist soils, making a firm sod able to withstand grazing and tramping by live stock. The sod of this grass is also useful in preventing soils from washing.

SOIL-For sour or acid soils, swampy or meadow lands liable to overflow, or soils not quite rich enough for Timothy, or other Grasses or Clovers, Red Top is especially valuable. It will not do well in sandy or leachy soils, but it is said to be adapted to a wider range of soil and climatic conditions than any cultivated grass grown in America.

SEEDING-If' sown alone, one bushel (14 lbs.) of solid seed per acre is the usual rate of seeding. If sown in the chaff, double this amount should be used. It may be sown alone either spring or fall, or with some small grain as a nurse crop. If covered after sowing, it should be done very lightly, rolling being preferable to brushing or harrowing.

HARVESTING-The proper time to cut Red Top, in order to secure best quality of hay, is when in full flower. It is more easily cured than any other grass; cut in the morning of a clear day-after the dew is off, it is ready to be raked into windrows in two hours, and put into cocks late in the afternoon.

It is often sown with other Grasses and Clovers, especially Timothy and Clover. These additions increase both the quality and quantity of the hay. The dense sod of Red Top will continue its growth for a longer period during the year than almost any other grass. 


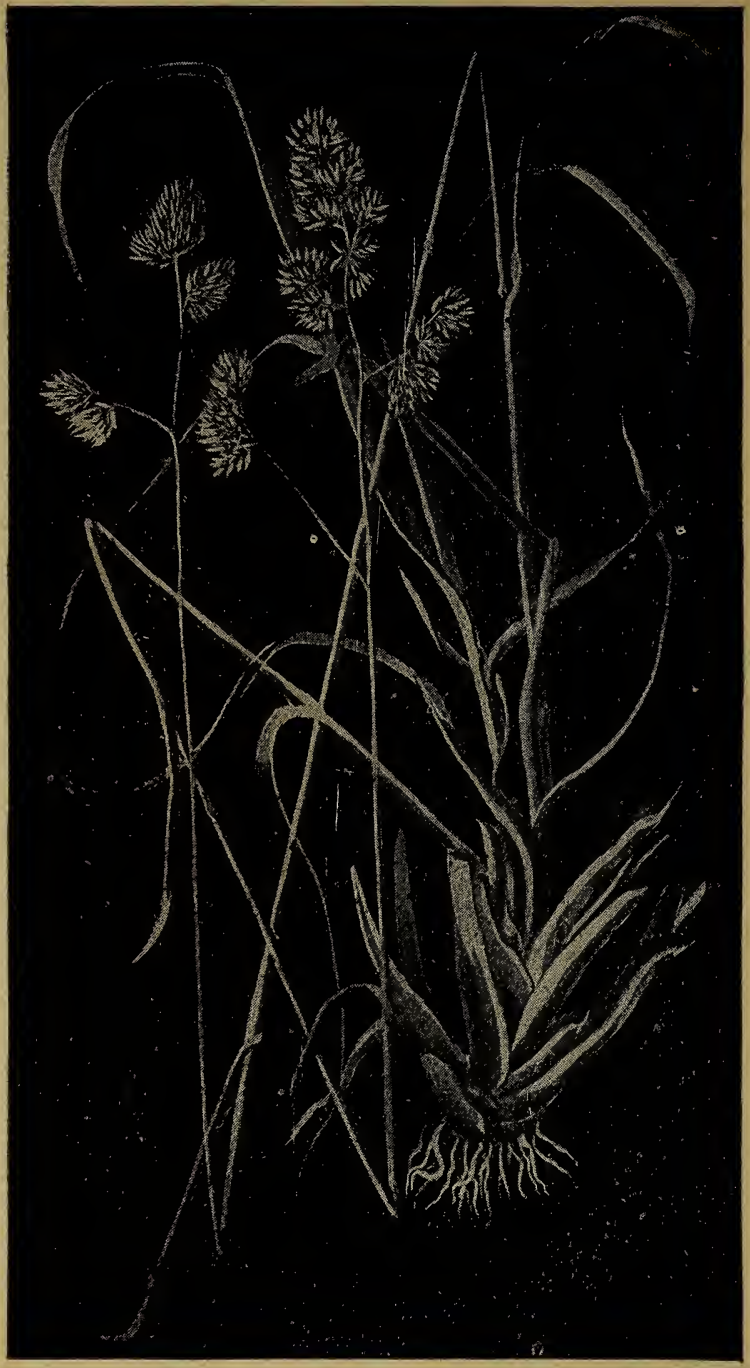

\section{Orchard Grass}

The Albert Dickinson Co., Chicago-Minneapolis 


\section{Orchard Grass}

(Dactylis glomerata)

Orchard Grass is a standard grass, grown to some extent in every state in the Union. It yields about the same amount of hay as Timothy, and, if cut at the right period, is nearly equal in feeding value.

SoIL-Orchard Grass grows upon every soil not saturated with water. Its preference is an alluvial soil, moderately dry, porous, and with a considerable amount of sandy material. It is easily established, however, on any fairly well-drained soil. The land should be ploughed deep, and the soil well-pulverized.

SEEDING - Twenty-five to thirty-five poinds of Orchard Grass per acre are required. A mixture of twelve pounds of Red Clover and twenty-five pounds of Orchard Grass is very desirable. Mixtures of Orchard Grass with other grasses, especially with Tall Meadow Oat Grass and Meadow Fescue, are giving good results for both hay and pasture. Orchard Grass is generally sown in the spring, but, under favorable conditions, will do well if seeded in the fall. It may be sown either with small grain or alone.

HARVESTING-It should be cut for hay the latter part of May or first of June, when it is just in bloom, as the quality is best at this stage and yield maximum. Curing should be done with as little sun as possible.

USES-It is both a pasture and hay grass. After a crop of hay has been taken off in May or June, the aftermath will furnish a desirable pasture throughout the remainder nf the summer and fall season. It stands grazing well, will resist drought better than almost any other grass, starts growth very early in the spring and is one of the latest grasses to be affected by frost in the fall. It will grow in the shade, which characteristic enables the farmer to utilize his wood lots as pasture. 


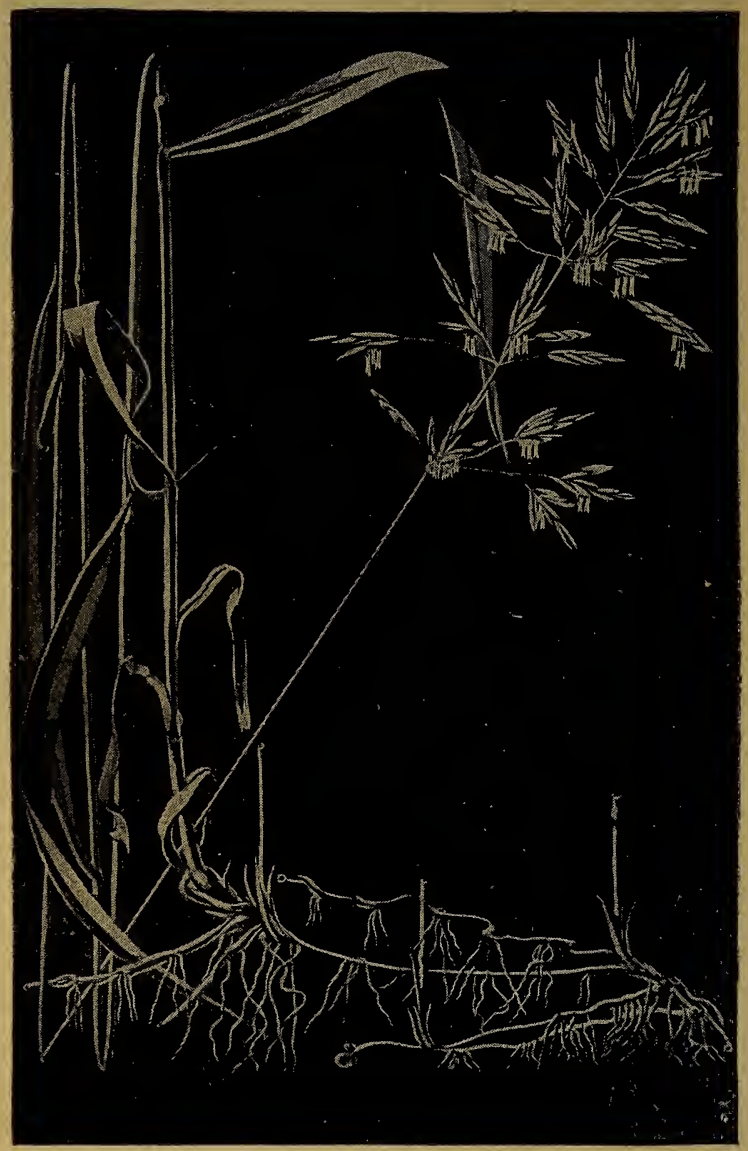

Smooth Brome-Grass .

50

The Albert Dickinson Co., Chicago-Minneapolis 


\section{Smooth Brome-Grass}

(Bromus inermis)

The introduction of beardless (also called smooth, Hungarian and awnless) Bromegrass into the arid and semi-arid regions of the West and Northwest has given the people of those states a pasture and meadow grass of great promise.

As it is thoroughly permanent and grows with wonderful rapidity, producing heavy crops and luxuriant pastures, its value to the farmers in dry regions cannot be overestimated. All kinds of stock eat it with relish, and chemical analyses show that it is rich in flesh-forming ingredients - much more so than Timothy. It is very hardy and, when once established, is not injured by severe spring and fall frosts. As it starts to grow very early in the spring before any of the grasses upon native prairies show any signs of life, and remains green and succulent far into November, it will supply the long-felt want of early spring and late fall pastures.

The yield of hay from Smooth Bromegrass varies from one to four and a half tons per acre. The quality of the hay is excellent, fully equaling that of Timothy in palatability and nutritive qualities. In order to obtain the best product, the hay should be cut at time of full bloom. One important feature which distinguishes Smooth Brome-grass from other hay grasses is that it does not deteriorate rapidly after the flowering period. After furnishing three or four crops of hay, the sod thickens up too much for a good growth of stems. This thickening occurs sooner if the grass is allowed to ripen seed, than it does when it is cut for hay, or if it has been seeded heavily at first.

The land should be fall plowed, disked and harrowed thoroughly, then seeded in the spring except in California, Oregon and Washington, and probably in the Southern States, where it is preferable to sow in October or November. Sow broadcast at rate of 18 to 20 pounds per acre and harrow thoroughly. 


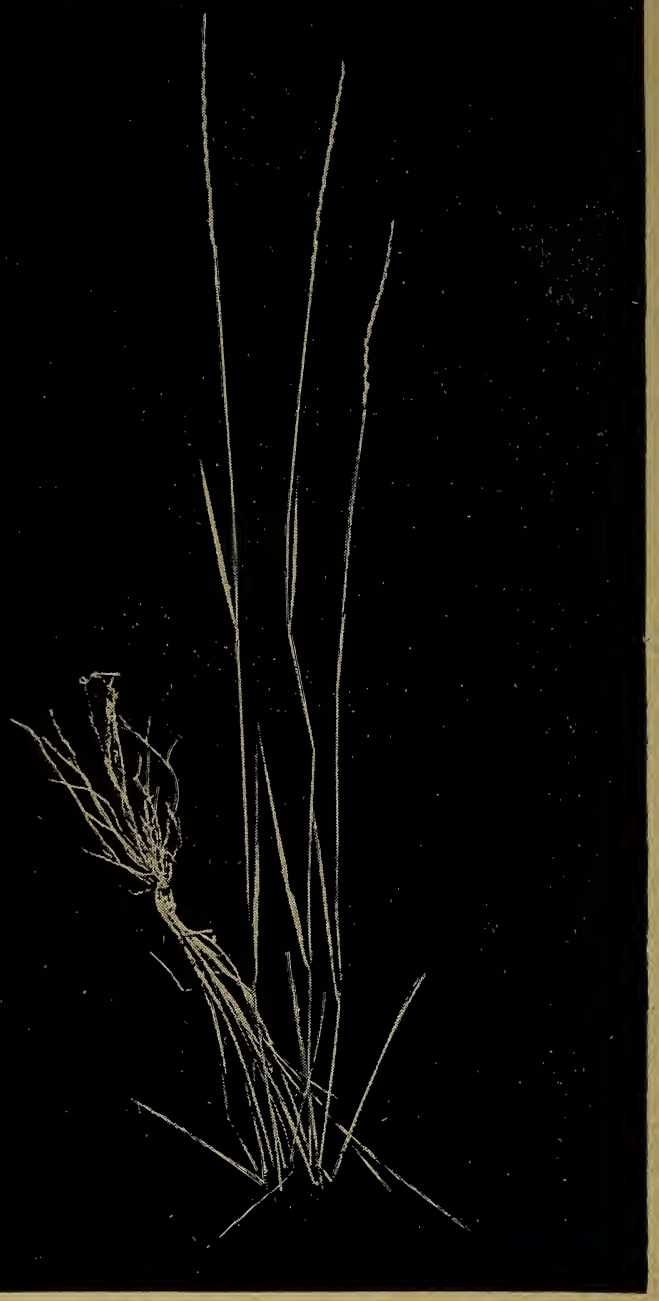

Slender Wheat Grass

52

The Albert Dickinson Co., Chicago-Minneapolis 


\section{Slender Wheat Grass}

(Agropyron tenerum)

Slender Wheat Grass, often called Western Rye Grass, is a native of this country and is cultivated in the Dakotas and the Canadian Northwest. The stems and seeds are similar to those of quack grass. The chief difference is in the root system. Quack grass, popularly known as a dangerous weed, has strong underground rootstocks while Slender Wheat Grass grows very fibrous roots, much similar to those of ordinary grains.

SEEDING-The seed is sown in the spring as early as possible on a well prepared and packed seed-bed. It is usually sown at the rate of 20 pounds per acre with a nurse crop. Care must be exercised not to cover the seed too deeply. When sown with a nurse crop, the grass does not yield hay the first season but produces heavily the second year. Some growers suggest sowing Red Clover with this grass. Such a mixture helps to overcome the slippery nature of the grass and makes it more easily handled; it also gives a better aftermath for pasture. It is not advisable to practice autumn seeding on account of the severe winters in sections where it is grown.

USES AND VALUES-Slender Wheat Grass is better adapted to use as hay than Bromus inermis, but does not afford as good a pasture since it does not propagate by root stocks and consequently does not withstand stamping and grazing. This grass is also becoming popular in crop rotation, especially in Northwestern Canada. For this purpose many farmers value it more than Bromus, as it can be plowed up without difficulty and the land seeded to some other crop.

HARVESTING THE SEED-When the crop is desired for seed, it is usually handled and threshed in the same manner as small grains. While not as heavy a yielder of seed per acre as Bromus, it is easier to handle and clean. 


\section{Millets \\ (Chaetochloa italica)}

Millets seldom have a regular place in farm crop rotation, but are used rather as a "catch" or substitute crop. Where Corn cannot be planted to advantage, land is rough, labor scarce, or there is liable to be a shortage of hay, Millets have long been a favorite crop. They are also an excellent crop to grow on foul land to get rid of weeds, giving practically the same results as fallowing, or summer cultivation, and in addition a crop of forage.

SOILS-Best results are obtained on rich - mellow soil, but Millets may be grown with varying success on a large variety of soils. They are shallow feeders and rapid growers, so that, if the surface does not contain the necessary available plant elements, barnyard manure or some other fertilizer should be applied.

SEEDING-They are rather sensitive to cold and seeding should in all cases be postponed until the danger from frost is past. However, seeding should take place before the dry period of summer begins. They may be sown broadcast or drilled. When grown for seed or silage, they are frequently drilled in rows far enough apart to permit cultivation, in which case about half the seed ordinarily sown is used. The amount usually sown per acre is from forty to fifty pounds of Common, Hungarian or German Millet and half of that for Siberian Millet.

HARVESTING-For hay purposes Millets may be cut when the heads begin to ap. pear until they are in late bloom. The cutting should never be delayed. until the seeds have formed nor is it advisable to harvest the crop for hay too early as it is apt to have a more or less laxative effect upon animals eating it.

SOILING-Under favorable conditions, the crop will be ready for feeding forty to fifty days from the time of seeding. 
SILAGE-No difficulty is experienced in making silage from Millets, but since they are so palatable and as easily handled as hay, they are likely to be handled in the latter way.

SEED-Millets may be harvested for seed in the same manner as ordinary grain. Time most suitable to harvest the crop for seed is when the seed is in the "stiff dough." Yields vary from 15 to 40 bushels per acre.

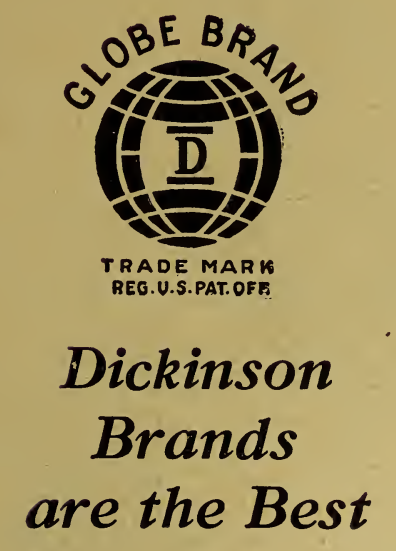




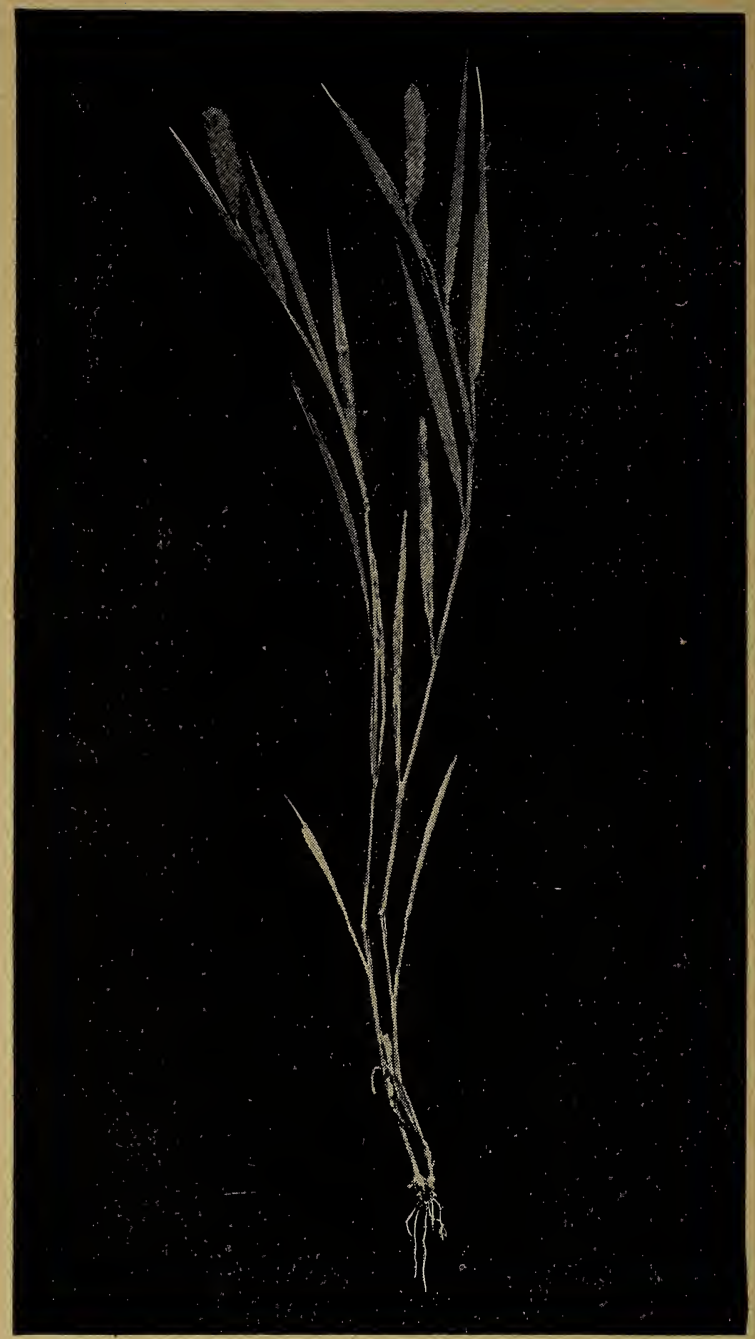

\section{Hungarian Millet}

56

The Albert Dickinson Co., Chicago-Minneapolis 


\section{Hungarian Millet}

(Chaetochloa italica)

Hungarian Millet, also called Hungarian Grass, was introduced into this country shortly after the introduction of Common Millet. It is well adapted to the northern Millet growing section where there is a reasonable amount of rainfall. The length of the growing season is intermediate between the Common and the Golden. This variety is giving excellent results over a wide territory and we believe that under suitable conditions it is one of the best varieties a farmer can grow. The quality of hay is somewhat better than that of Golde $\mathrm{n}$ and next to Common. While not as drought resistant as Common Millet, it will usually produce better yields under favorable rnaditions of soil and climate. It has a teidency to persist in the soil when allowed to mature seed before harvesting, but seldom becomes troublesome except on light sandy soils or those recently brought under cultivation. The heads are short, erect, dark purple in color and very compact. Seeds are yellow and purple in color and oval in shape. Stems are slender, have a tendency to branch, and bear rather narrow green leaves. Like Common this variety produces a number of plants from one seed.

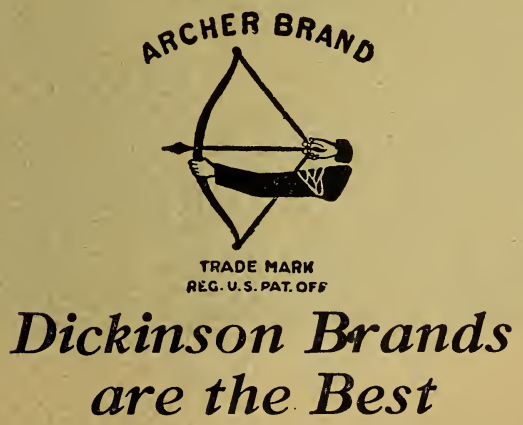

The Albert Dickinson Co., Chicago-Minneapolis 


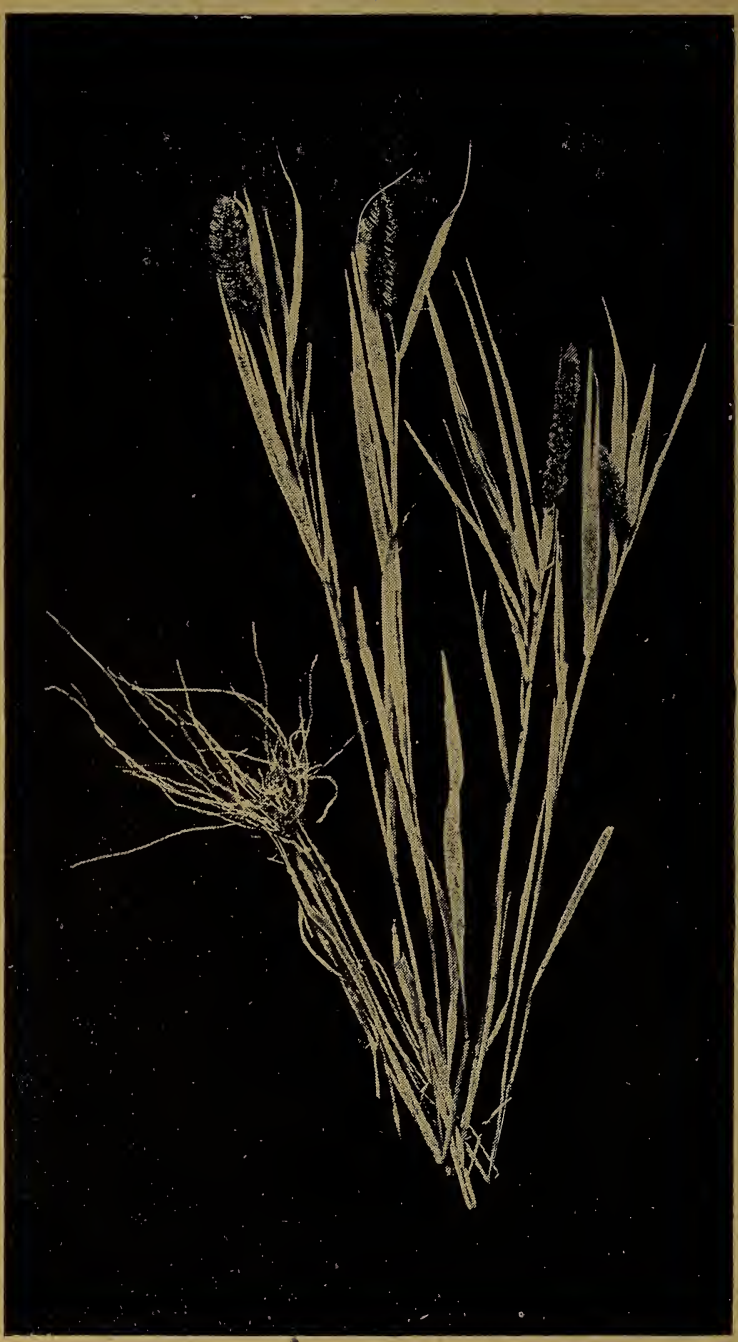

Golden Millet

The Albert Djekinson Co., Chicago-Minneapolis 


\section{Golden Millet}

(Chaetochloa italica)

Golden Millet is a very popular variety in the South and Central States where it has been under cultivation since the early sixties. It thrives best in soil subject to considerable rainfall and will not resist drought as well as the smaller varieties. The growing period is from 14 to 21 days longer than that of Common or Hungarian Millet. The hay is coarser and less highly valued for feed. However, when the forage can be fed in the green state, it will be found to be an excellent variety to grow because of the high yield.

Golden Millet is a later developed variety and is not constant in its characters. When examining a field many, perhaps most, of the heads may be typical of the variety, but usually there are many which can scarcely be distinguished from Common Millet or other standard varieties. Typical Golden Millet grown in the South becomes much modified when grown in the North. The heads are large and broad, and composed of clustered branches with purplish awns. Leaves are rather short and broad. Seeds, like those of Common Millet are yellow but smaller in size.

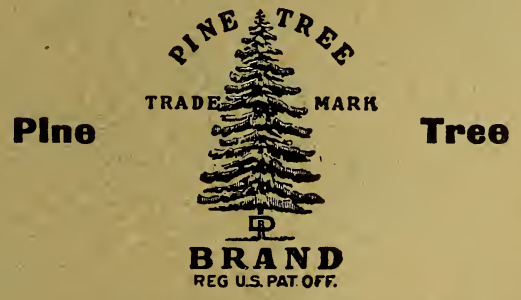

IT STANDS ALONE 


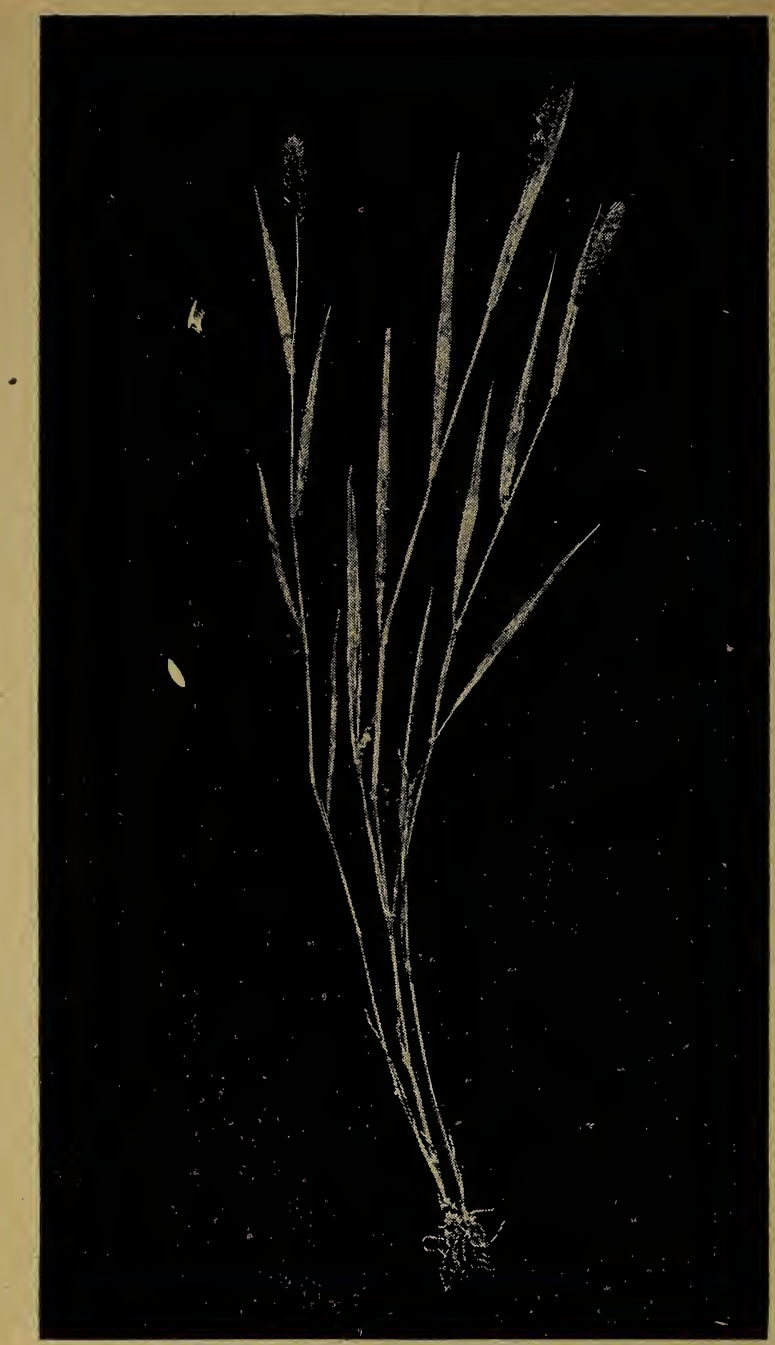

Common Millet

60

The Albert Dickinson Co., Chicago-Minneapolis 


\section{Common Millet}

(Chaetochloa italica) .

Common Millet was one of the first of the foxtail millets to be introduced and come into general cultivation in the U. S. It is also the earliest and hardiest variety srown in the northern part of the Millet belt. It is very drought resistant and will produce a fair crop on the poorer classes of soils. Under ideal conditions of soil and moisture, stock feeders prefer this Millet for hay to others because of its finer quality, there being less loss in feeding it. Golden Millet usually produces better yields under favorable conditions of soil and moisture, but under average conditions Common Millet produces more forage of finer quality in the Northern States.

Although one of the earliest of the foxtail Millets, it is most constant in its characters. The heads are nodding, medium in size, rather compact at the tip, but open at the base, and taper toward the tip. Seeds are somewhat larger than those of Hungarian or Golden, oval in shape, and yellow in color. Stems are slender, do not usually branch, and produce broad leaves. This Millet stools freely, especially, when grown on rich soil.

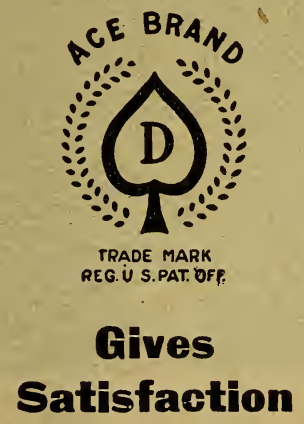

61

The Albert Dickinson Co., Chicago-Minneapolis 


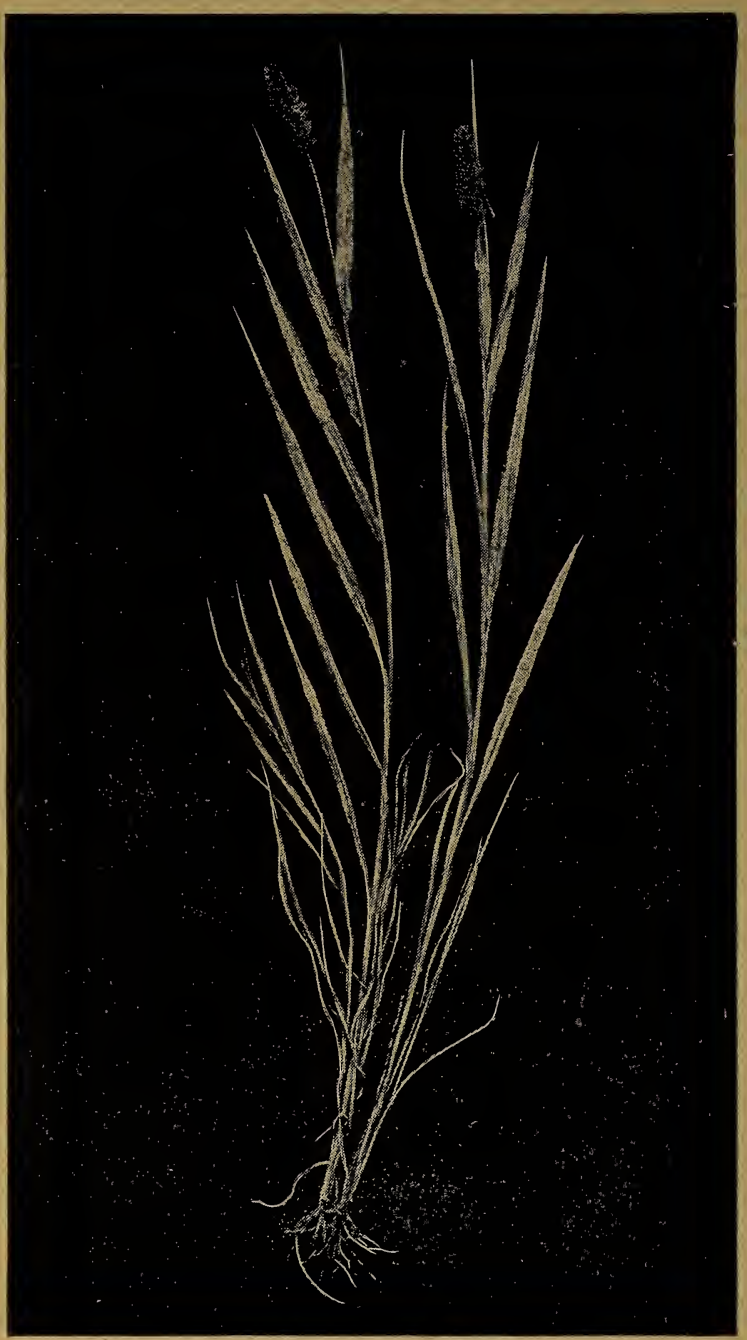

\section{Giberian Millet}

The Albert Dickinson Co., Chicago-Minneapolis 


\section{Siberian Millet}

(Chaetochloa italica)

Siberian Millet is regarded as one of the best varieties for general cultivation in the Western States. Like many other valuable plants this variety of Millet was introduced into this country by the United States Department of Agriculture from Russia. It belongs to the foxtail group under which Common, Hungarian, and Golden Millets are classified. It matures about the same time as Common and Hungarian Millets and has been successfully grown in sections where the season is too short to mature a corn crop.

The habit of growth, beard, and chaff are much similar to Hungarian Millet. The heads are drooping, somewhat larger than either those of Common or Hungarian Millets, tapering at both ends, with rather conspicuous, closely flowered subdivisions. Seeds are of about the same size and shape as those of Common and Hungarian Millets, but white to orange in color.

Probably no variety of Millet produces a heavier yield of either seed or forage, or a better quality of hay. Its abundant growth of stalk and drought resistant qualities has brought it into high favor among stockmen in the Northwestern States.
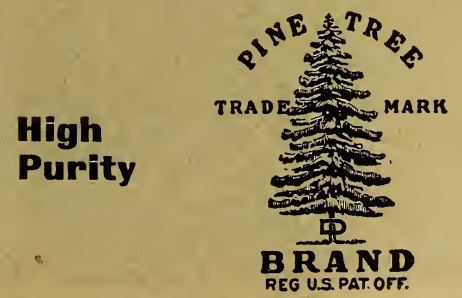

Moderate Cost 


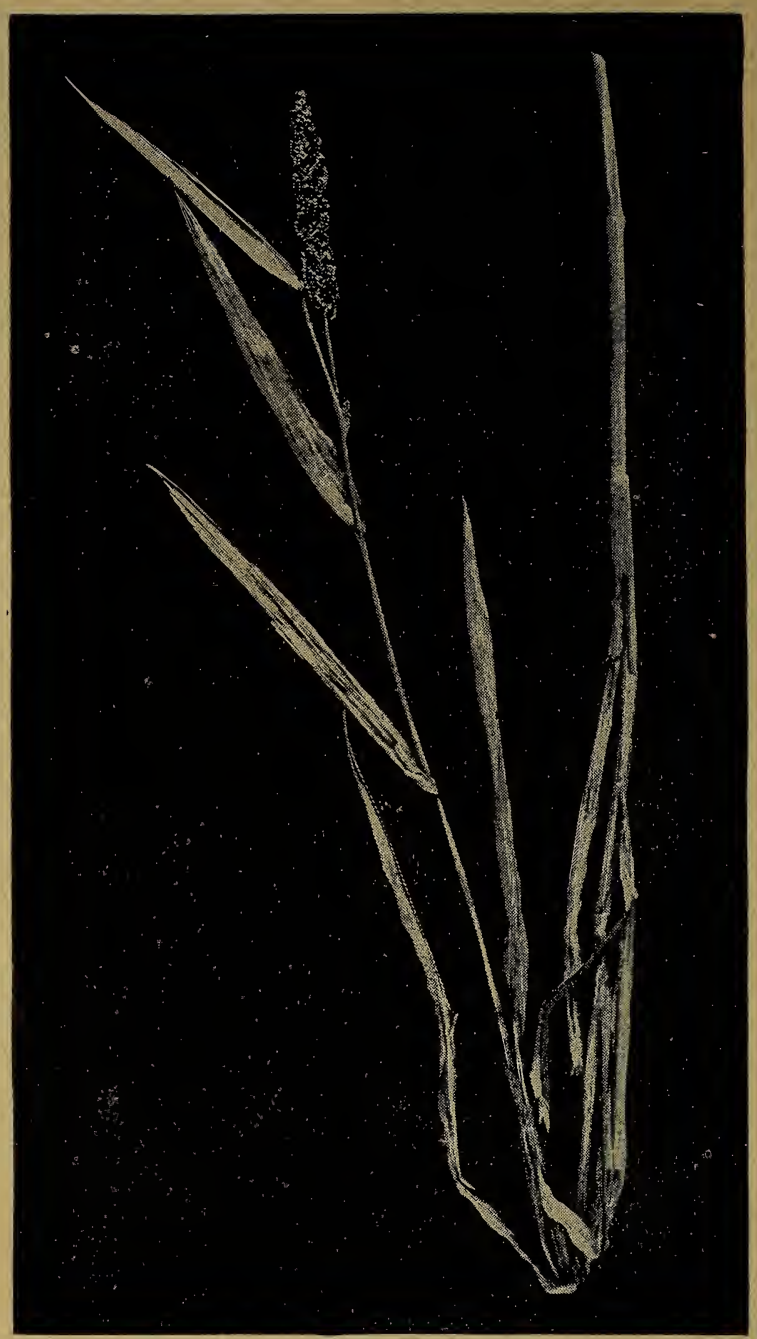

Japanese Millet

64.

The Albert Dickinson Co., Chicago-Minneapolis 


\section{Japanese Barnyard Millet \\ (Panicum Crus-galli)}

The seed from which, so far as known, all the Japanese Barnyard Millet now cultivated in the United States has descended, was brought to Amherst from Northern Japan in 1889 by Wm. P. Brooks, now Director of the Massachusetts Agricultural Experiment Station.

Throughout Japan the seed of this Millet is considerably used as human food, being prepared in many ways which are peculiar to the country. The capacity of this Millet for seed production is very great. It has sometimes yielded in Amherst nearly 100 bushels of 35 pounds each per acre. In composition, the seed closely resembles Oats and in feeding experiments in Amherst, meal made by grinding the seed, fed in connection with other grains has seemed to be fully equal to oatmeal in rations for milch cows. The seed is valuable also as food for poultrý.

It is not, however, as a seed crop that the Japanese Millet will be principally valued in the United States, but for forage.

1. For Green Feed: In the opinion of the introducer, the Japanese Barnyard Millet is likely to prove of greater value as a green food than for any other purpose. Its capacity for production is great. The forage is tender and highly relished and in nutritive value appears to be about equal to the best green Corn fodder. Yields at the rate of rather more than twenty tons per acre are easily obtained. In using this Millet as a green food, it is best to begin cutting just before the heads appear. That portion of the Millet which is cut prior to the formation of the seed will produce a considerable second crop, which may be either cut for later feeding or fed off, as preferred.

2. As an Ensilage Crop: The introducer regards Japanese Millet as superior 
for ensilage to any of the cereal grains except Corn, or to any of the other Millets.

3. As a Hay Crop: Japanese Millet, on account of extreme succulence, is a somewhat difficult crop to cure. If well cured, however, chiefly in the cock, it makes an extremely palatable and nutritious hay highly relished by all classes of stock, particularly by horses, which seem to prefer it to good Timothy hay. So far as is known, moreover, hay from this species of Millet does not cause kidney troubles, which often follow the free use of hay made from the other varieties of Millet.

\section{SOIL AND CLIMATIC ADAPTATION-} Japanese Millet requires for most satisfactory results rather rich and retentive soils. On the thin, light soils, liable to suffer from the effects of protracted dry weather, it will prove unsatisfactory. This Millet will be found of great value throughout the northern half of the United States, except in the semi-arid belt lying between the Missouri and the Rockies, and even in this section it can undoubtedly be grown with great success under irrigation.

TIME AND MANNER OF SOWING-The heaviest crops are obtained from relatively early sowing in any given locality, within those dates best suited for the planting of corn. It grows rapidly, and in the latitude of Amherst has given yields as high as twelve tons per acre of green forage when sown as late as the first of July. For seed production, the Millet should be sown in drills, but for forage broadcast sowing is best. From twelve to fourteen pounds of seed per acre will be sufficient on good soils for relatively early sowing. On poorer soils and for late sowing, the quantity of seed should be proportionately increased.

It is better to be safe than sorryinsist on sowing Dickinson's "Pine Tree." 


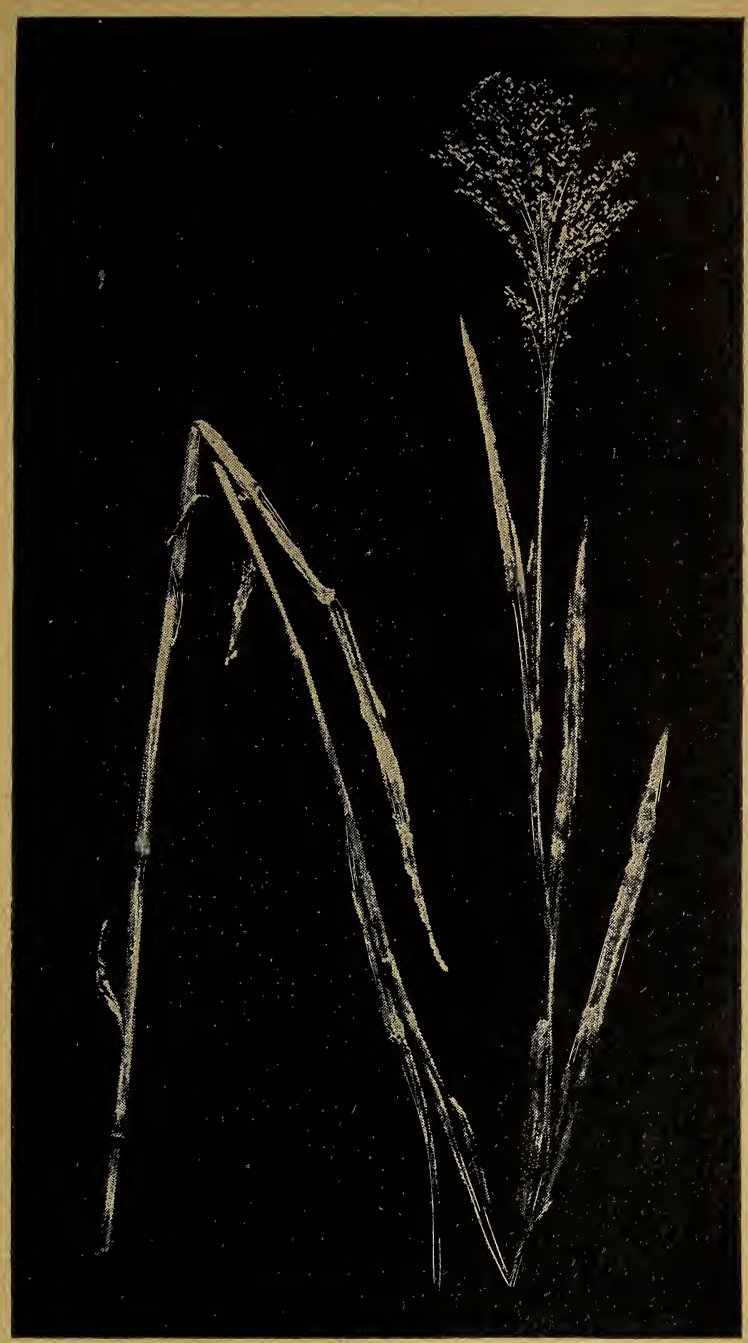

\section{Broom Corn Millet}




\section{Broom Corn Millets}

(Panicum miliaceum)

Broom Corn Millets have not come into general use in the United States, but are grown extensively in Europe. In the Northwest this crop is highly prized because of its ability to mature a crop of seed in short, dry seasons, thus serving to some extent as a substitute for Corn.

VARIETIES-The different cultivated varieties differ in habit of growth and character of heads, but are chiefly distinguished by the color of the seeds. The latter may be white, yellow, red, or even black. The varieties most popular in the Northwest are Broom Corn and Early Fortune Millets. The Broom Corn Millets will grow on a variety of soils, but the best results are obtained on loams with little clay and not too much sand.

SEEDING-Like foxtail Millets, these Mil lets are rather sensitive to cold and seeding should be postponed until the ground is thoroughly warm. However, it should take place before the dry spell of summer begins. A succession of crops for soiling or silage can be practiced by sowing at periods of two or three weeks from May 10 th to late in July. For hay purposes, use from one-half to three-fourths of a bushel, and for seed from eight to twelve pounds per acre.

HARVESTING-For soiling or for hay, Broom Corn Millets, may be cut as soon as they "head out" or before. Best quality of hay, however, is obtained by cutting the crop during the bloom stage.

For silage they may be cut any time between heading out and the formation of seeds. When desired for seed these Millets are harvested like ordinary grain during the late dough stage. Yields varying from 50 to 60 bushels per acre are frequently reported from the Northwest.

USES-The seed is richer, both in pro- 
tein and fat than that of foxtail millet. Very satisfactory results have been obtained in feeding it to swine and young cattle, and is an excellent grain on which to prepare animals for the market. It is better adapted for human food than the seed of any other Millet grown in this country and makes a good poultry food.

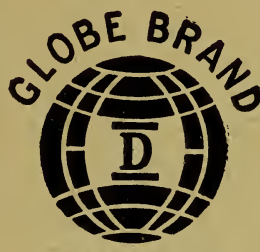

TRADE MARK REG.U.S.PAT. OFE

\section{Dickinson}

\section{Brands}

\section{are the Best}




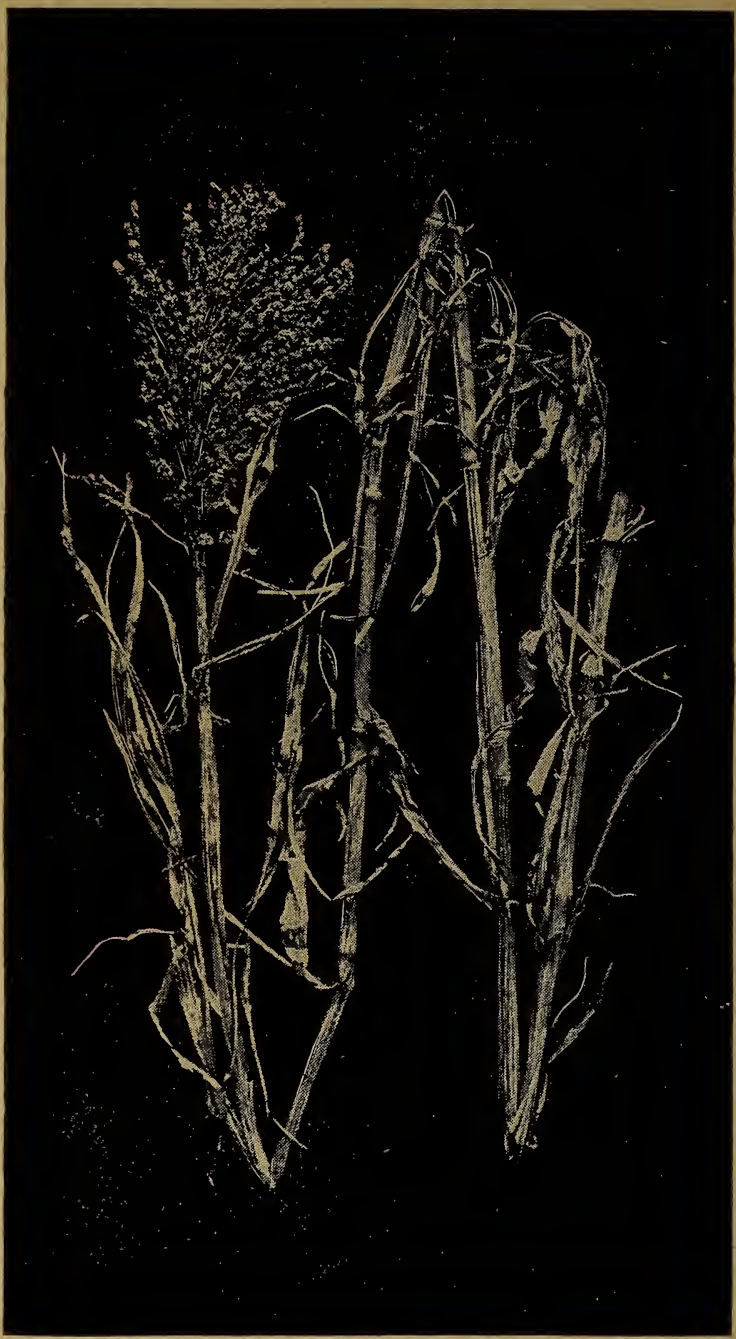

Amber Cane

The Albert Dickinson Co., Chicago-Minneapolis 


\section{Amber Cane}

(Andropogon sorghum Brot.)

Amber Cane is one of the oldest and earliest maturing varieties of Sorghum now in use. It requires approximately 70 to 100 days to mature, depending on soil and climatic conditions. Because of its early maturity it has become very popular in the Northern sections of the United States.

SOILS-The best yields are obtained on rich sandy loams, but when grown on gumbo, hard pan, or other poor soils, it is more successful than other crops. Since the growth of the plants is very slow during the first few weeks, it is essential to have the soil free of weeds and of good tilth, otherwise the plants may be overwhelmed with weeds.

SEEDING-Soil preparation same as for corn. May be sown broadcast at the rate of 75 to 100 pounds per acre, thus producing a fine quality of hay, or planted in rows 21 to 24 inches apart to permit cultivation. For soiling or silage purposes, 8 to 10 pounds to the acre are planted in drills.

CULTIVATION-When sown broadcast, it may be safely harrowed until 4 to 6 inches high without injury to the plant. Drilled fields may be first cultivated with a light spike tooth harrow driving over the fields parallel to the rows.

HARVESTING-For silage or fodder, like corn, Cane is best harvested when the seed is in dough stage, using an ordinary Corn binder. Fields that are sown broadcast may be advantageouslv harvested with a grain binder. Dry fodder of Cane is equal if not superior to Corn because of its juicy and palatable stems. For hay, it may be harvested any time after large enough to cut as ordinary Millet hay, though the best qualities are obtained shortly after blooming.

YIELDS-Reports range all the way from five to forty tons of green forage, and from two to twelve tons of hay per acre. Growers of both Sorghum and Corn agree that Sorghum ordinarily outyields Corn for forage except in the heart of the Corn belt. 


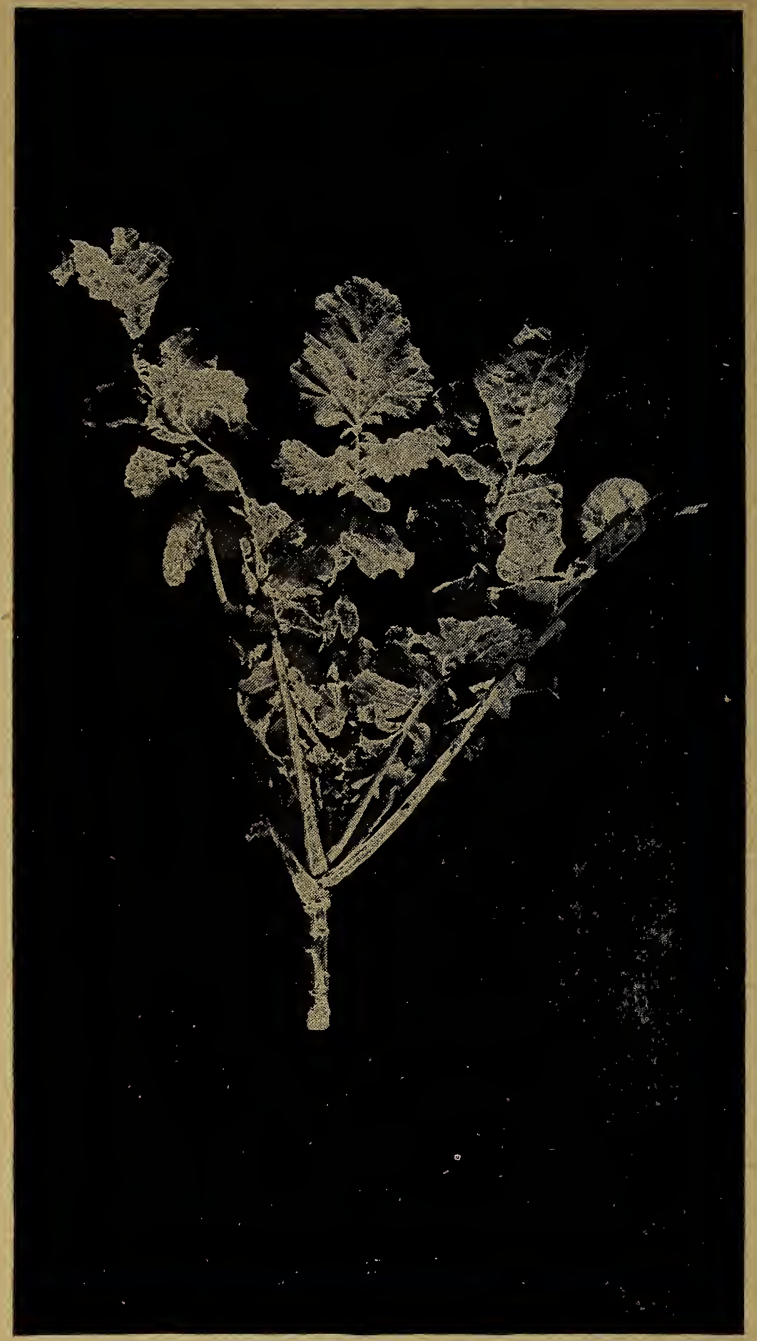

Dwarf Essex Rape

The Albert Dickinson Co., Chicago-Minneapolis 


\section{Dwarf Essex Rape}

Dwarf Essex Rape is a biennial plant of great forage value. A much larger acreage of this forage crop could be grown to advantage for green feed during the summer and fall months when the supply of grasses and Clovers is often limited.

SOIL-For its best development Rape requires a rich, moist, loamy soil, but will usually do well in any but light sandy soils and stiff clays.

SEEDING-Throughout the Northern States, seeding as a rule takes place from the first of May until the last of July. Under favorable conditions use three to four pounds of seed per acre and preferably drill it far enough apart to allow cultivation. With favorable conditions, good crops may be obtained from broadcast seeding.

In some sections it has been found profitable to sow Clover and Rape together. A good stand of Clover is obtained in this way, and the two make a good hog or sheep pasture during the fall months.

Rape is sown on Corn ground, just preceding the last cultivation. This makes a splendid fall feed for cattle, sheep or swine.

CULTIVATION-If the seed has been drilled, the crop should receive at least three or four cultivations during its early growth.

USING THE CROP-The Rape is usually ready for use in about 8 or 10 weeks from date of seeding. Stock as a rule is turned into the field, and allowed to remain until the Rape is pastured off. It is said to be without a rival in all the list of succulent summer and fall feeds for sheep.

DANGER FROM BLOATING-Cattle, sheep and hogs may suffer seriously from bloating, if sufficient care is not taken. It is best to give the animals a full feed, have them well satisfied with other food before they are turned into the Rape. Wait until the dew is off and leave them on but a short time the first day. Salt should be freely supplied. 


\section{Wheat}

\section{(Triticum vulgare)}

The history of Wheat is coincident with that of man. The early lake dwellers of Switzerland cultivated a variety during the Stone Age, while the Chinese grew Wheat 2700 B. C.

Wheat may be classified into spring and winter varieties, into hard and soft varieties, or according to botanical differences.

CLIMATE AND SOILS-Wheat is adapted to a very wide range of climate, but the best yields and best qualities of Wheat are produced in a temperate climate where the seasons are sufficiently long to allow 100 to 125 days of good growing weather and where the rainfall is not less than 20 inches, quite uniformly distributed throughout the growing period.

SEEDING-A thorough preparation of the soil by fall plowing and cultivating is desirable for the growing of either spring or winter Wheat. Seeding time of winter Wheat in the Northern sections varies between the 10th of September and the last of September. In the case of spring Wheat, seeding should take place as early as weather and soil will permit. Sowing 6 to 8 pecks per acre in drills has been recommended by several experiment stations.

HARVESTING-Wheat is considered mature when the berry is in the dough stage and the straw begins to turn yellow. If harvested too early, there is apt to be a loss in yield as the increase of grain is most rapid up to the soft dough state. Cutting is usually carried on with a grain binder which binds the grain into bundles. These should be put into round shocks, and capped with one or two extra bundles to prevent the Wheat heads from being exposed to rain and dew. Preservation of the bright color in Wheat is very desirable in good milling Wheat.

THRESHING-When weather conditions permit, the most economical practice is to 
thresh directly from the shock. During rainy seasons or in humid sections, it is preferable to store the grain either in stacks or barns, and allow it to sweat.

USES-Wheat is primarily used for the production of flour from which different forms of food are made, while its by-products, which are of high feeding value, are fed to domestic animals.

YIELDS-Yields vary greatly with climate, soil and cultural methods. Different cultural methods in growing Wheat were tried out at Kansas Experiment Station and the yields obtained varied from $41 / 4$ to $381 / 3$ bushels per acre. The average yield of Wheat in the United States is 14 bushels per acre.

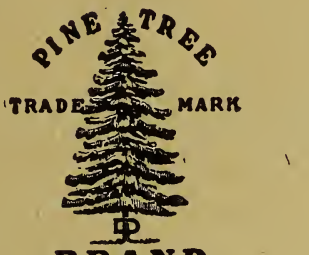

BRAN D REG US PAT. OFF.

\section{Dickinson}

\section{Brands}

\section{are the Best}




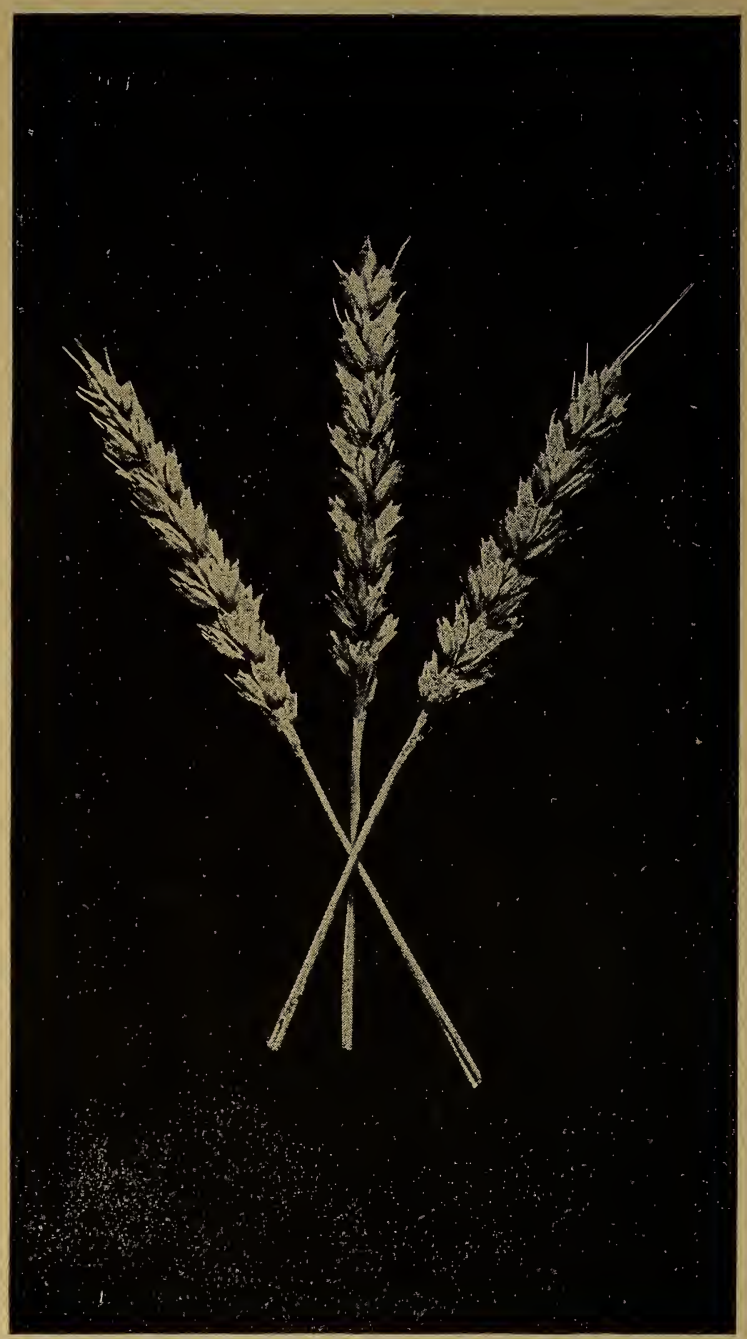

Fife Wheat

The Albert Dickinson Co., Chicago-Minneapolis 


\section{Fife Wheat}

It is generally agreed that Fife Wheat was originally introduced from the northern Volga River valley district of Russia, but confirming details are lacking. Much credence is given to the following statement published by the Canadian Agriculturist of 1891.

"About the year 1842, Mr. David Fife, of the township of Otonabee, Canada West, now Ontario, procured, through a friend in Glasgow, Scotland, a quantity of Wheat which had been obtained from a cargo direct from Danzig. As it came to hand just before spring seed time, and not knowing whether it was fall or spring variety, Mr. Fife concluded to sow a part of it that spring and wait for the result. It proved to be a fall Wheat, as it never ripened, except three ears, which grew apparently from a single grain. These were preserved and although sown the next year under unfavorable circumstances, being quite late and in a shady place, it proved at harvest to be entirely free from rust, when all Wheat in the neighborhood was badly rusted.

The produce of this was carefully preserved and from it sprung the variety of Wheat known over Canada and Northern States by the different names of Fife, Scotch, and Glasgow." It is a popular hard spring Wheat of the Northern Great Plains and Canada becoming established at the introduction of the purifier and roller mills in 1870. It is considered the best bread Wheat. The plant grows to medium height but ripens several days earlier than Bluestem, which very often enables it to escape rust and drought or frost in the Northern latitudes. The glumes or outer coverings of the grain are white, smooth, and awnless. Kernels are dark red, rather broad in proportion to the length, have very wide grooves and are slightly harder than those of the Bluestem.

Like Bluestem it is reasonably drought resistant, seldom lodges, and is considered somewhat more hardy. 


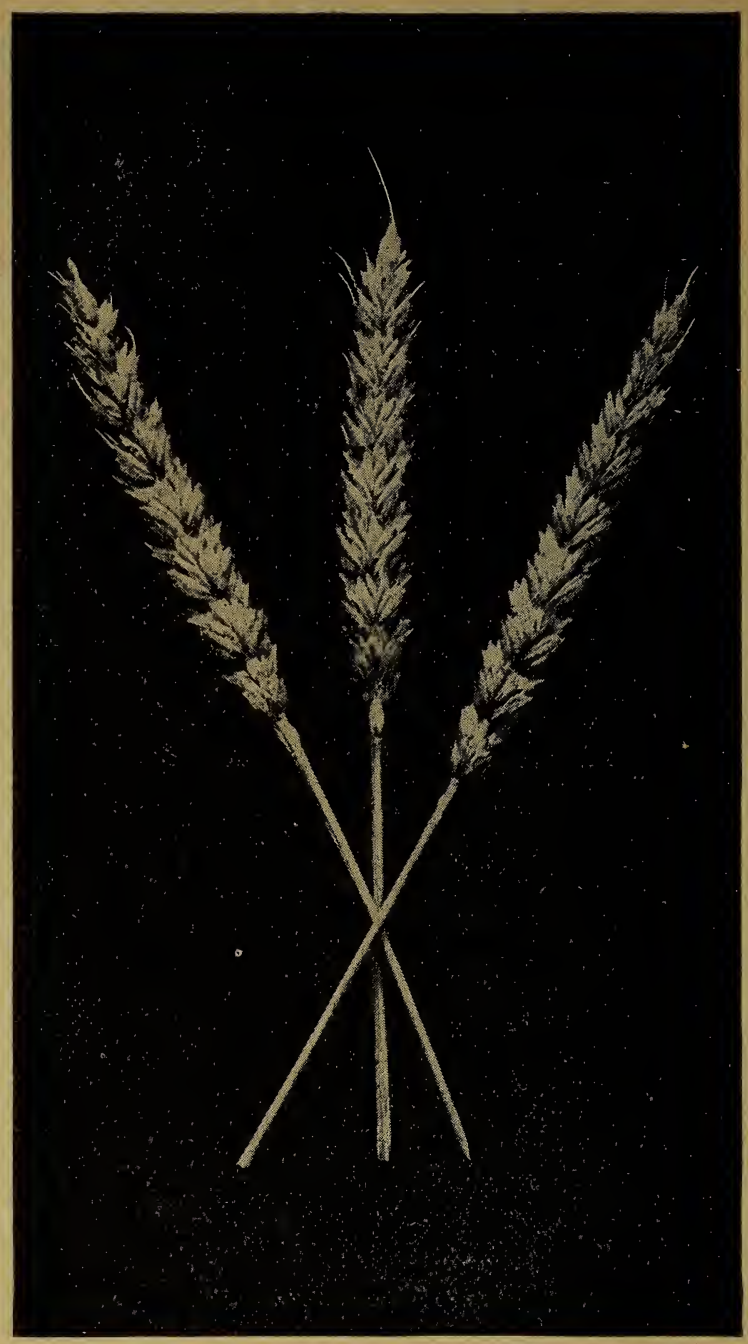

\section{Bluestem Wheat}

The Albert Dickinson Co., Chicago-Minneapolis 


\section{Bluestem Wheat}

Data relative to the time and source of introduction of Bluestem Wheat into the Northern Great Plains and Canada are very indefinite. However, like Fife Wheat, it was not firmly established as a profitable crop until 1870, coincident with the introduction of the purifier and roller mill. It is a very popular hard spring Wheat grown throughout the Northwest and in some localities yielding much higher than Fife. It is slightly inferior to Fife as a bread Wheat but under favorable conditions the quality of the flour is practically the same. It grows somewhat taller, is reasonably drought resistant, seldom lodges, but requires from 3 to 10 days longer to mature. Heads are beardless, glumes or outer covering white and velvety. Kernels are dark red with wide out-curving grooves, and somewhat larger but slightly softer than those of the Fife.

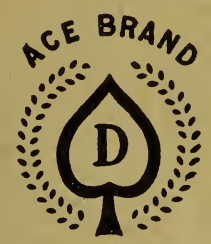

TRADE MARK REG. U S.PAT. OFE:

\section{Dickinson}

\section{Brands}

are the Best 


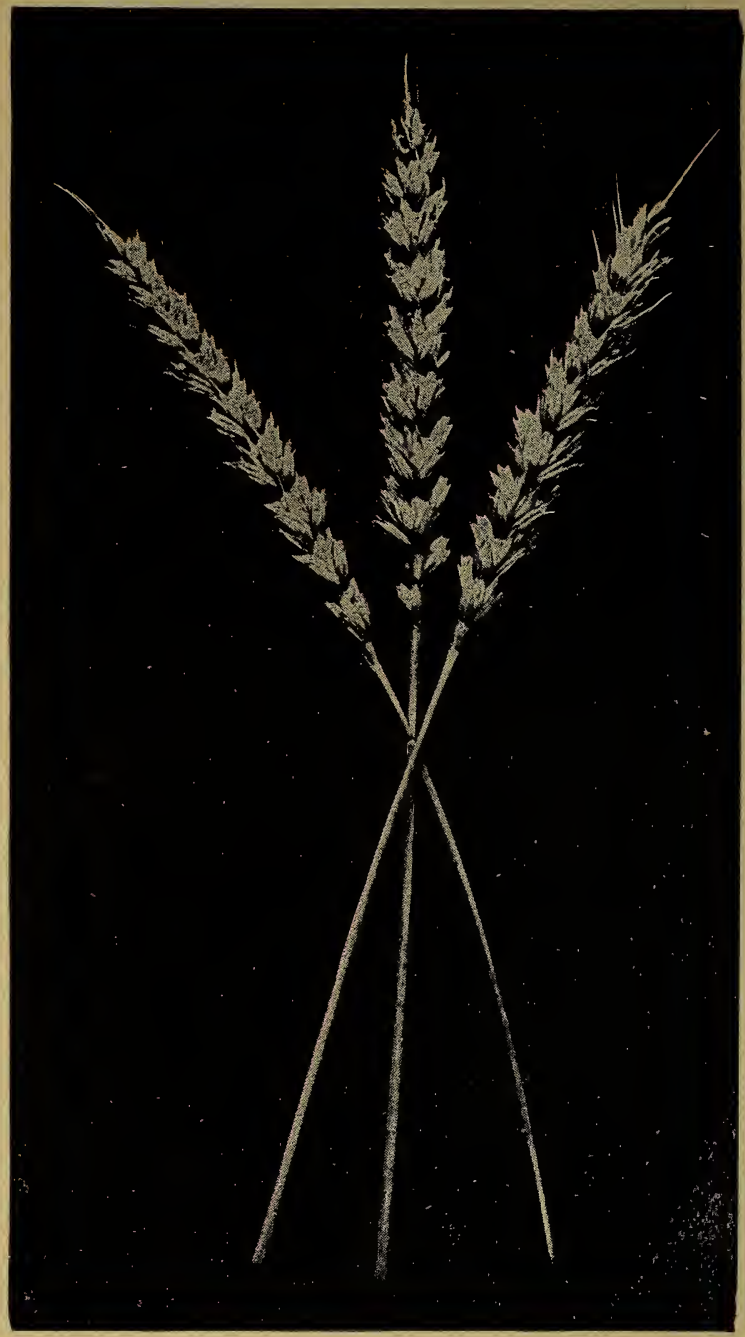

\section{Marquis Wheat}

*

80

The Albert Dickinson Co., Chicago-Minneapolis 


\section{Marquis Wheat}

Marquis Wheat is of Canadian origin, developed and propagated at the Central Experiment Station, Ottawa, Canada. In 1903 Marquis Wheat among other cross-breds was selected on high gluten content by Dr. C. E. Saunders. The following year it was grown separately, but not until the baking test in 1907 was made were its fine qualities of high strength in breadmaking and good color demonstrated. That same year it was sent to Saskatchewan for field trial, where it proved superior to all known varieties.

The kernel is short, broad and plump, has a trough shaped crease similar to that of Fife, and weighs well per bushel. The color of the kernels is from a medium to dark red. The texture of the grain varies with the season and the kind of soil on which the Wheat is grown.

It is a beardless variety with the exception of a few awns near the tip. It grows to medium height, has good strength of straw and matures 3 to 10 days earlier than the Fife or Bluestem. An early maturity often insures grain against severe attacks of rust and hot weather, or frost in northern latitudes. This advantage resulting in increased yields. On the uniform trial plots at Brandon Marquis Wheat yielded $10 \%$ more than Red Fife during a period of four years and $50 \%$ more at Indian Head during a five year test. Although a comparatively new variety, its popularity is rapidly increasing in the Wheat growing sections.

\section{Your protection lies in seeing our brands on the bags.}




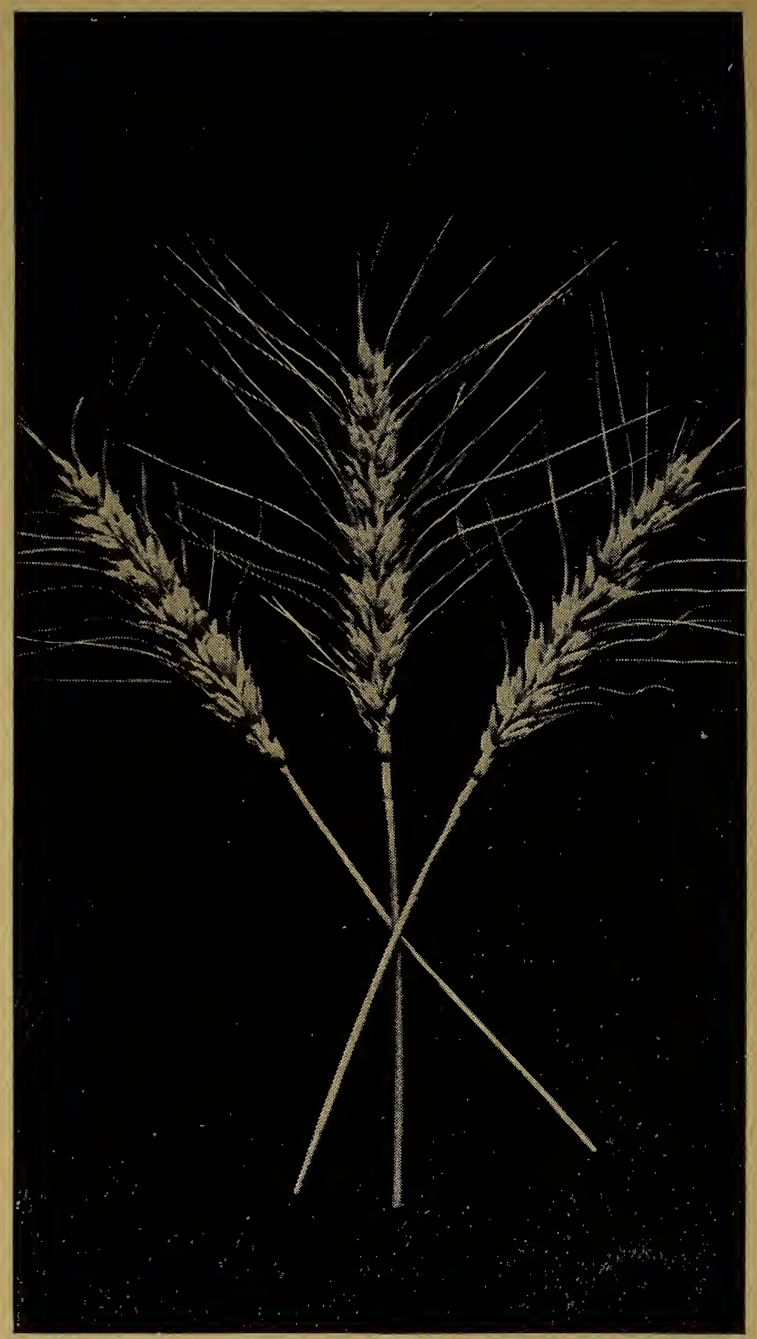

Preston (Velvet Chafi)

The Albert Dickinson Co., Chicago-Minneapolis 


\section{Preston (Velvet Chaff)}

Preston or Velvet Chaff Wheat is a common spring bearded Wheat with smooth white glumes or chaff. The kernels are hard, red in color, and of medium size. This Wheat appears better adapted to eastern and central South Dakota than elsewhere, although it is a very popular Wheat in parts of Minnesota and North Dakota.

The number of days required to mature the crop is from 80 to 100 days. It is drought resistant but is more susceptible to rust than the Fife Wheat. In some sections it yields higher than any of the spring Wheats including Durum. The amount of flour produced is about equal to that of Fife Wheat but hardly equal to the Bluestem. The volume of loaf is slightly less than either the Fife or Bluestem.

The name Velvet Chaff is a misnomer, because the glumes" of this Wheat are smooth. For this reason the United States Department of Agriculture has adopted the original name "Preston" for the group of bearded common spring Wheats, as most of the bearded Wheat grown is the Preston variety which originated in Canada.

It was bred from a cross between Lodaga, a Siberian Wheat, and the well known Red Fife by Dr. A. P. Saunders of Ottawa, Canada, in 1888. This variety was first grown by the Minnesota Agricultural Experiment Station in 1895, as Minn. No. 188. It was widely distributed under the number in. stead of under the name Preston. Very soon the seed appeared on the market at different places under various names. Besides the name Velvet Chaff, bearded spring Wheats are often called Bearded Red Fife or Bearded Fife, but these names are misleading as these wheats are really not Fife Wheats, so that the name Preston is preferable. 


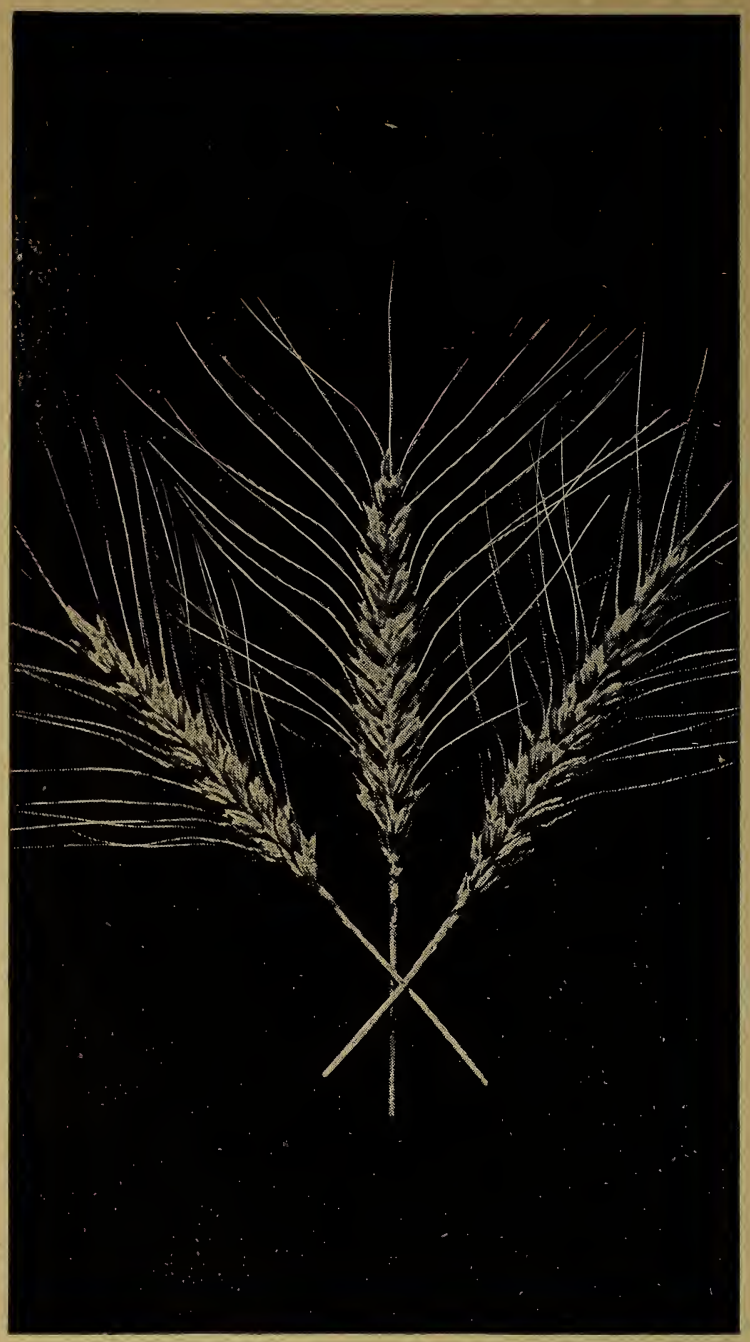

\section{Turkey Red Wheat}

The Albert Dickinson Co., Chicago-Minneapolis 


\section{Turkey Red Wheat}

The original home of Hard Winter Wheat is in the area of Russia just north and east of the Black Sea and north of the Caucasus mountains. Soil and climatic conditions in certain sections of our great plains are strikingly similar to those of the original home. Turkey Red Wheat was first introduced into the U. S. in the early seventies by emigrants from Crimea who settled in Kansas.

It is a bearded variety, with grain of good milling quality, and white chaff that holds the kernel firmly in the head, preventing shattering. The head is of medium size, nearly square at the center, and rather tapering towards the tip. Kernels are thick in proportion to length, and dark amber in color. The gluten content is large, practically equal to that of hard spring Wheat, but differs in quality. The expansive power or strength is slightly less and there is possibly a shade more of color in the hard winter Wheat bread than in the hard spring. Of the hard winter Wheats, Turkey Red is considered as the best bread Wheat. Throughout the central and eastern United States, the straw grows weak and has a tendency to lodge, but under dry land conditions, it stands up well and causes little or no trouble.

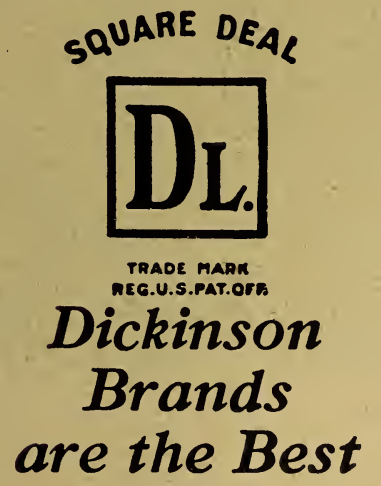

85

The Albert Dickinson Co., Chicago-Minneapolis 


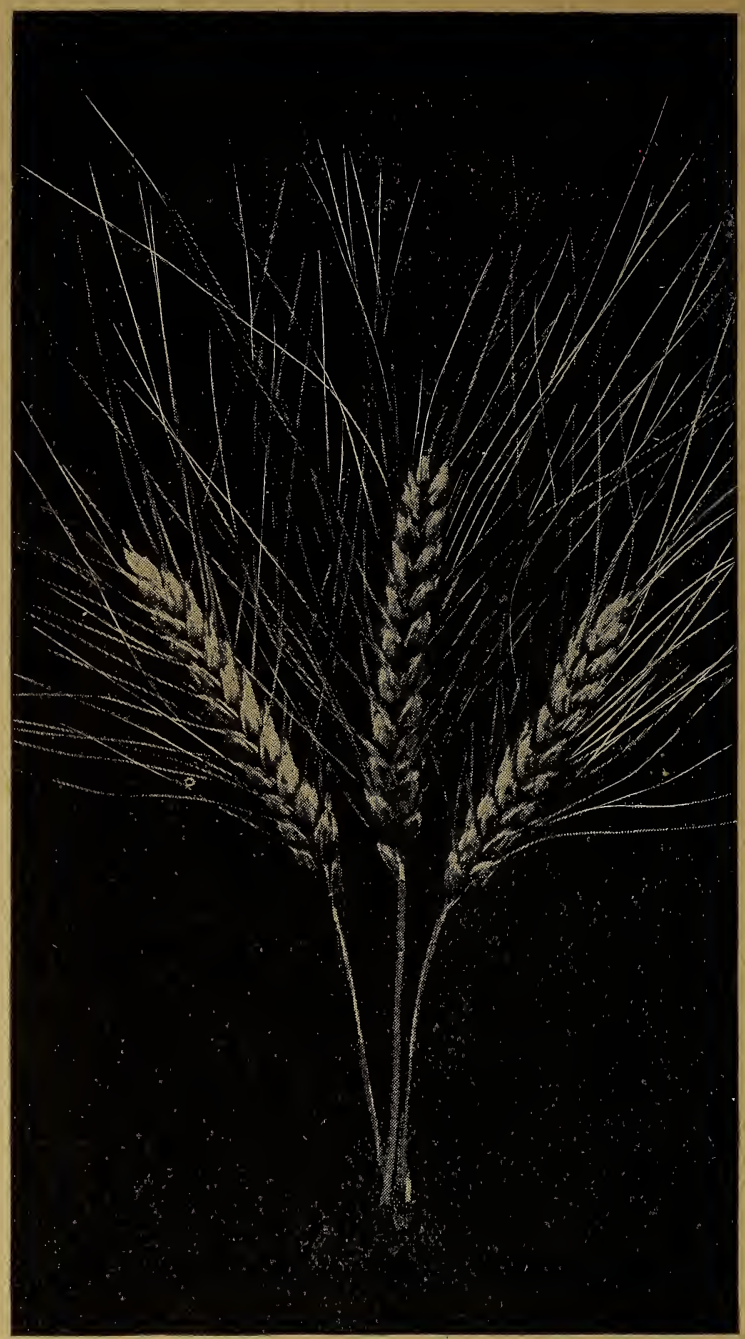

\section{Durum Wheat}




\section{Durum Wheat}

(Triticum durum)

Since 1901 Durum Wheat has become an important variety of Wheat, wonderfully increasing the grain production in this country especially in semi-arid sections. It owes its popularity in regions of low rainfall to its drought, smut, and rust resistance, to its vigorous growth, early maturity, and its productiveness.

Durum Wheat is usually taller, has wider leaves and grows more vigorous than common Wheat, but tillers less. The heads are heavily bearded, large in size, and vary from light yellow to black in color depending upon the variety. The kernels are large, very hard, being less starchy than common varieties, and vary in color from light yellow to reddish yellow.

The quality of Durum Wheat is lowered when grown in humid areas or in seasons that are abnormally wet. Durum is used primarily in the manufacture of a coarse flour called semolina, from which macaroni and other forms of edible pastes are produced, and in the production of flour for baking. Bread made from Durum Wheat flour is yellow in color and smaller in size, but the absorption or strength of this flour is in most cases higher than that of common varieties and this results in more loaves per barrel of flour. The bread has a distinct nutty taste, is slightly sweeter, and holds moisture better than bread made from other flours.

Cultural methods are similar to those of other Spring Wheats except in the rate of seeding. The amount to sow per acre depends largely on soil and local conditions but under favorable circumstances from 3 to 5 pecks will give good results. In sections most adapted to its growth, yields' from 40 to 50 per cent over common Wheat are produced, and a gain of from 15 to 25 per cent for Durum in more humid areas. 


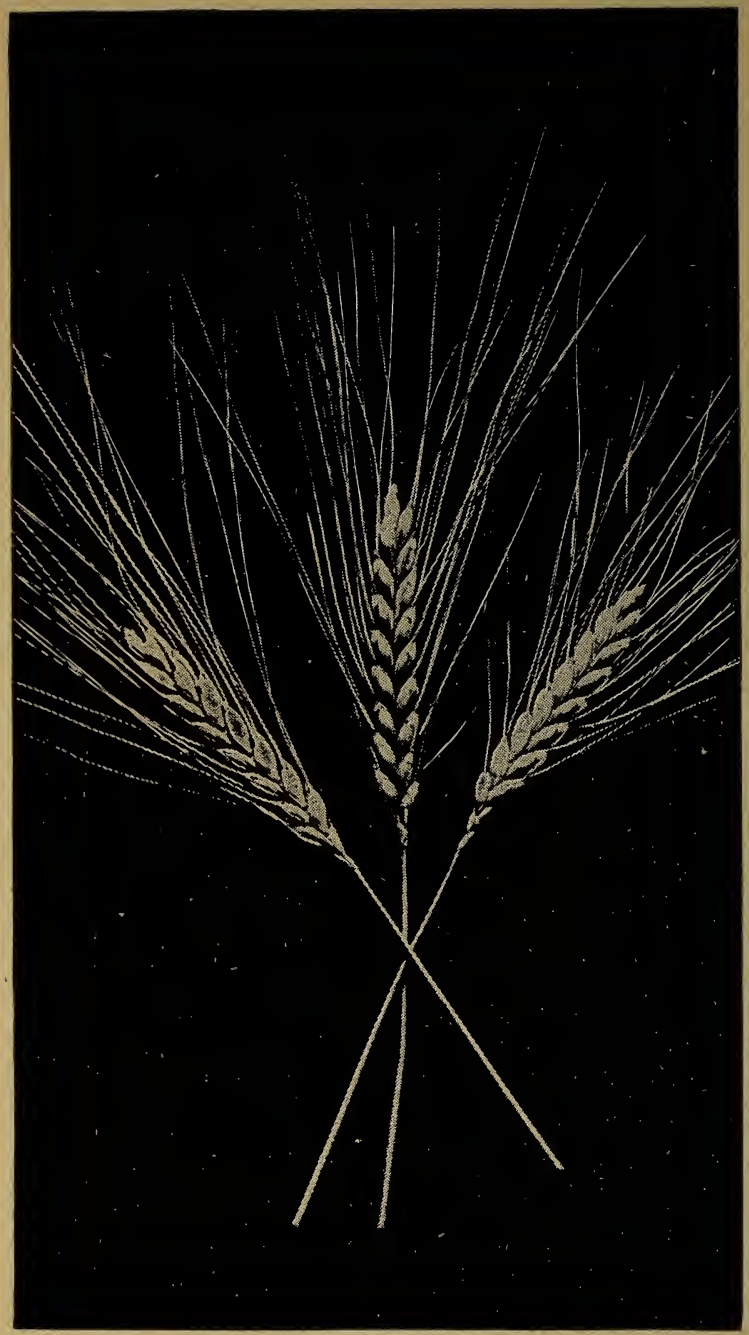

\section{Emmer}

The Albert Dickinson Co., Chicago-Minneapolis 


\section{Emmer}

(Triticum diccocum)

Emmer, wrongly called Speltz, is a specie of Wheat cultivated since prehistoric times. It is successfully grown in all our Northern States from Minnesota to Washington, in Alaska, and in semi-arid districts further south. It is also fairly well adapted to humid areas.

This Wheat is classified into winter and spring varieties. The latter is being cultivated most extensively in the North. A description of the plant and seed is applicable to both. The straw is stiff, and somewhat taller than that of the ordinary Wheats. Leaves are broad and usually velvety, heads almost always bearded and much flattened on the two-row sides. The spikelets generally conta in two kernels, compressed in shape, one located slightly higher than the other. Thesse remain in the spikelet after threshing.

Emmer has the characteristic quality of yielding well under almost an:y conditions of soil or climate. It grows on poor or stony or prairie soils, and in forest regions. The best yields and qualities of Emmer, however, are produced in prairie regions having a dry climate with short lnot summers. It is more drought, rust, and smut resistant than ordinary varieties of Wheat. Nor is it as easily damaged by rains in! wet districts during harvest time.

CULTIVATION-In the Northern States the usual methods employed in growing spring grains are followed. Best results are obtained on ground plowed the previous summer. It is very important to sow early in the spring. The seed is preferably drilled at the rate of $11 / 2$ to 3 bushels per acre. When sown broadcast, which is often the case in Russia, the rate of seeding varies from 4 to 12 bushels per acre. 
USES-Emmer may be used as an intermediate crop when the soil has become exhausted by the growth of other more exacting crops. It is highly valued as a crop for. stock feeding. The grain compares favorably with Oats or Barley for that purpose and the straw is considered by some to be of much value. In this country very little of the grain is used for human consumption, whereas, in Russia, large quantities are used for porridge or for other kinds of breakfast foods.

YIELDS-Yields ranging from 25 to 65 bushels per acre are reported by experimenters and stations.

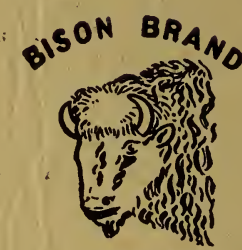

TAADE MARK

EEG.U.S. PAT. OFE.

\section{Dickinson}

Brands

\section{are the Best}




\section{BARLEY \\ (HORDEUM SPP.)}

Like Wheat, Barley has been closely allied with the progress of civilization. Even up to the sixteenth century it was the chief bread plant of continental Europe, but from then on, its use has declined through the introduction of potatoes and the increasing use of Wheat.

Barley is commonly classified into tworowed and six-rowed types. Under this classification there are bearded, beardless and hulless varieties. The six-rowed is the one generally grown throughout the United States. It has a stiffer straw than the tworowed and is usually a higher yielder.

SOIL-Largest returns are obtained on well drained loams. Its shallow root system enables it to respond more readily to good tillage and fertilizers than any other grain. However, it does not appear to stand growing continuously on the same land as well as other cereals, nor does it do well on ground newly cleared or where the land is not well drained.

SEED-BED-As in the case of other cereals, fall plowing is desirable as fallplowed land can be brought into shape earlier and holds moisture better. The time of seeding should be later than of Oats or Spring Wheat since the young Barley is very susceptible to frost. It is usually sown with a drill or broadcast seeder at the rate of $1 \frac{1}{2}$ to 2 bushels per acre.

CUTTING AND SHOCKING-The market value of Barley is largely governed by the color of the grain, and this is influenced by the period ripeness. The brighter the color, the higher is the price. The proper time to cut Barley is when most of the plants are yellow-ripe and the kernels are in the dough stage. If cut when the straw is yet green, the kernels will shrink and assume an ashen color that is not desirable, yet if the crop is cut after the proper stage, there is a loss" 
in shattering and the grain becomes discolored. The shocking should be done on the day of harvesting. To prevent exposure to dew, sunlight and rain, which decreases the market value of the grain by injury to its color and vitality, it is advisable to put the bundles in round shocks and cap these with two others. The latter bundles should be threshed separately as much discolored Barley will be found in the cap bundles and should not be mixed with the other. After the Barley has been cured in the shock, it should be stored in bays or stacked.

THRESHING-In operating the machine, it is essential that the speed of the cylinder and the position of the teeth in the concave be properly adjusted. Frequently Barley is threshed directly from the shock, but this practice prevents the barley from going through its natural sweating process while in the straw. It will then sweat in the bins and extreme heat often accompanies the sweating process and this causes a deterioration in quality.

USES-Barley is primarily used for malt. ing and feeding purposes. Practically all the Barley grown in the United States is the six-rowed Barley and is freely used in the production of malt, whereas, in Europe the malters prefer the two-rowed on account of the thin hull and low percentage of protein. The six-rowed is generally grown there for feeding purposes. On the Pacific Coast, particularily in California, Barley is grown as a substitute for Corn and Oats, since it grows better than either of these crops. It has about the same feeding value as Wheat or Corn, and somewhat higher feeding value than Oats. When cut in the milk stage, Barley may be cured into bright dustfree hay of good quality. It is also an excellent nurse crop to use when Clovers or Grasses are to be sown.

YIELD-Under favorable conditions of soil and climate, 35 to 40 bushels are obtained, although higher yields per acre are not unusual. 


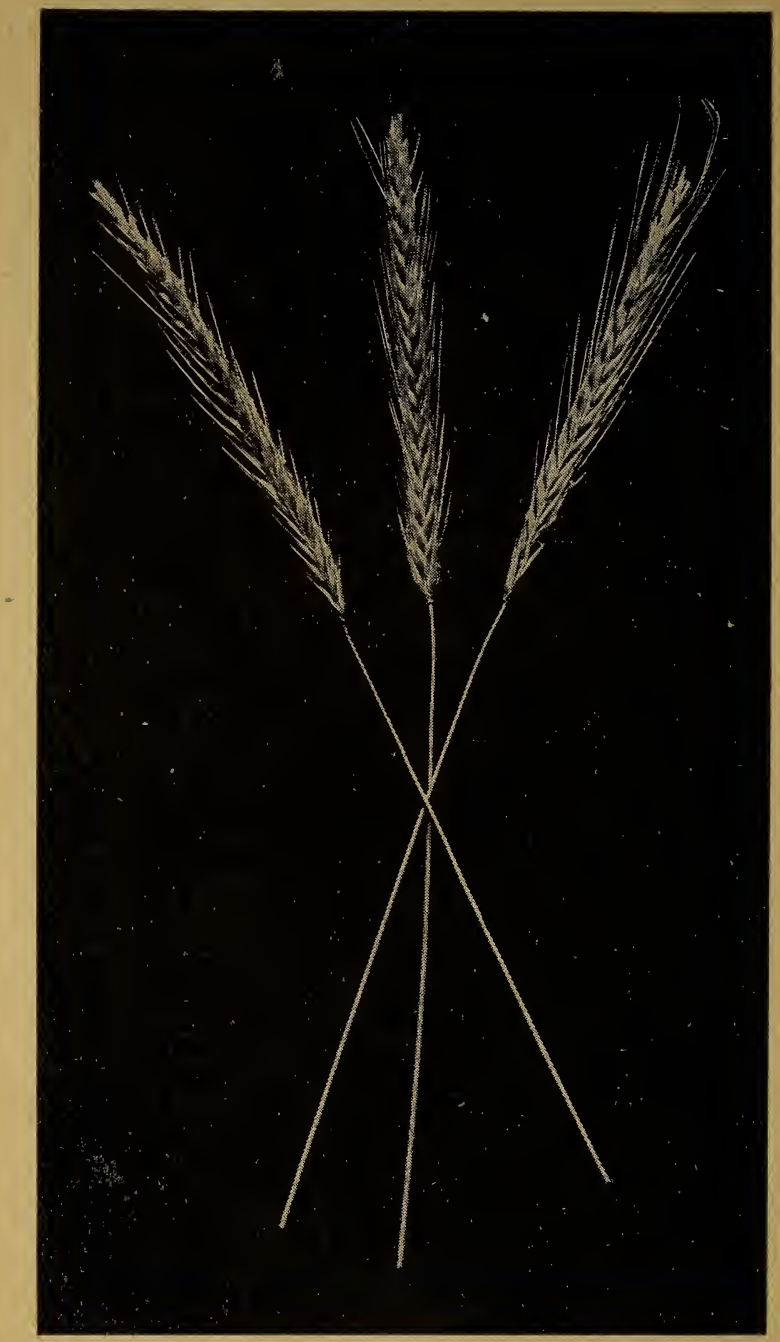

Rye

94

The Albert Dickinson Co., Chicago-Minneapolis 


\section{RYE}

(SECALE CEREALE)

The two popular varieties offered on the market are spring and winter. The latter is iore generally grown as it is hardier, yields setter, and there are very few localities where it will not succeed.

SoIL-Rye is best adapted to a light sandy soil of medium fertility, but will produce a fair crop on soils too poor for other cereals.

SEED-BED-The seed-bed is prepared in a manner similar to that of Wheat regardless' of variety. The grain may be sown broad cast or in drills at the rate of five to six pecks per acre. The time of seeding is just before or about the same time as Wheat.

HARVESTING AND THRESHING Methods of harvesting and threshing are like those of other cereals, excepting where the grain is to be threshed without mutilating the straw and in such cases special machines are used.

. USES-Rye bread is one of the chief foods of many of the people of Northern Europe, whereas', in America, the demand for Rye bread is' very small. Rye straw is of little value as a feed but is extensively used in the shipping of nursery and crockery and in the manufacture of straw articles such as plates, dishes, trunks, etc. Rye is also used in the manufacture of alcohol and alcoholic beverages, and as food for domestic animals. Winter Rye, when sown early, may be pastured several months in the fall without reducing the yield of the srain. A crop of Rye is frequently plowed inder as green manure to add humus to the soil. Rye is an excellent nurse crop in which to start Clovers and Grasses.

YIELD-The average yield of Rye of the United States is about 16 bushels per acre. 


\section{Oats}

\section{(Avena sativa)}

Oats are best adapted to a cool, rather moist climate, and are most extensively raised in the Temperate Zone. All cultivated varieties may be classified into two general classes-closed panicle and open panicle. They may also be divided into spring and winter varieties.

SOILS-Best yields are obtained on well drained fertile clay, or clay loam soils. Oats are usually sown on soils low in fertility because they have a tendency to grow rank and lodge. The seed-bed should be prepared by plowing rather than by disking or harrowing and that should be done preferably in the fall.

SEEDING-The seeding of Oats should be carried on as early in the spring as the ground can be put into proper condition, as the best results are obtained when the crop has made as much growth as possible, before hot weather. The usual rate of seeding is from 2 to 3 bushels per acre.

HARVESTING-Oats are usually cut with a grain binder at the time they are in the hard dough stage. If harvested before this time, the grain is not filled and is light in weight. Like other grain, the bundles are put into round shocks and capped with one or two additional bundles to prevent exposure to rain and dew.

STACKING AND THRESHING-It is usually advisable to stack Oats, though threshing from the shock is a popular and economical practice. Stacked grain should be allowed to stand for at least two weeks prior to threshing. After that period the sweating process is over.

YIELDS-In the irrigated sections of the Rocky Mountain region, yields from 150 to 175 bushels are sometimes reported. The average yield of Oats in the United States 
for ten years (1900 to 1909 ) was less than 30 bushels per acre.

USES-Oats have long been the staple grain feed for horses, and are still considered as the best and safest feed for that class of animals. They are also an excellent food for cattle and sheep especially for ewes and milch cows. Ground Oats mixed with swill make an excellent feed for brood sows and are highly recommended by swine raisers.

Oat straw is more nutritious and is more readily eaten by live stock than straw of other cereals, and is practically equal to Corn stover. Oat hay is richer in proteln and fat than Timothy hay.

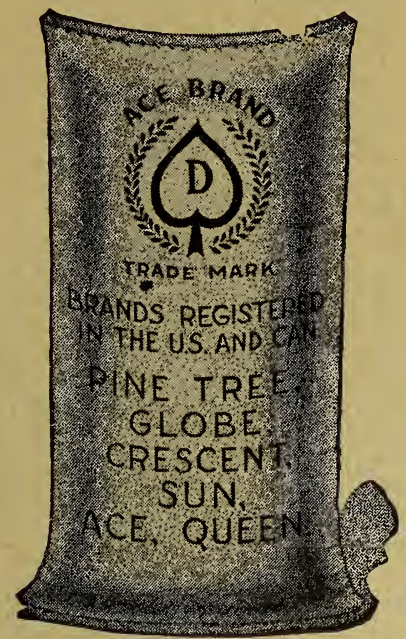




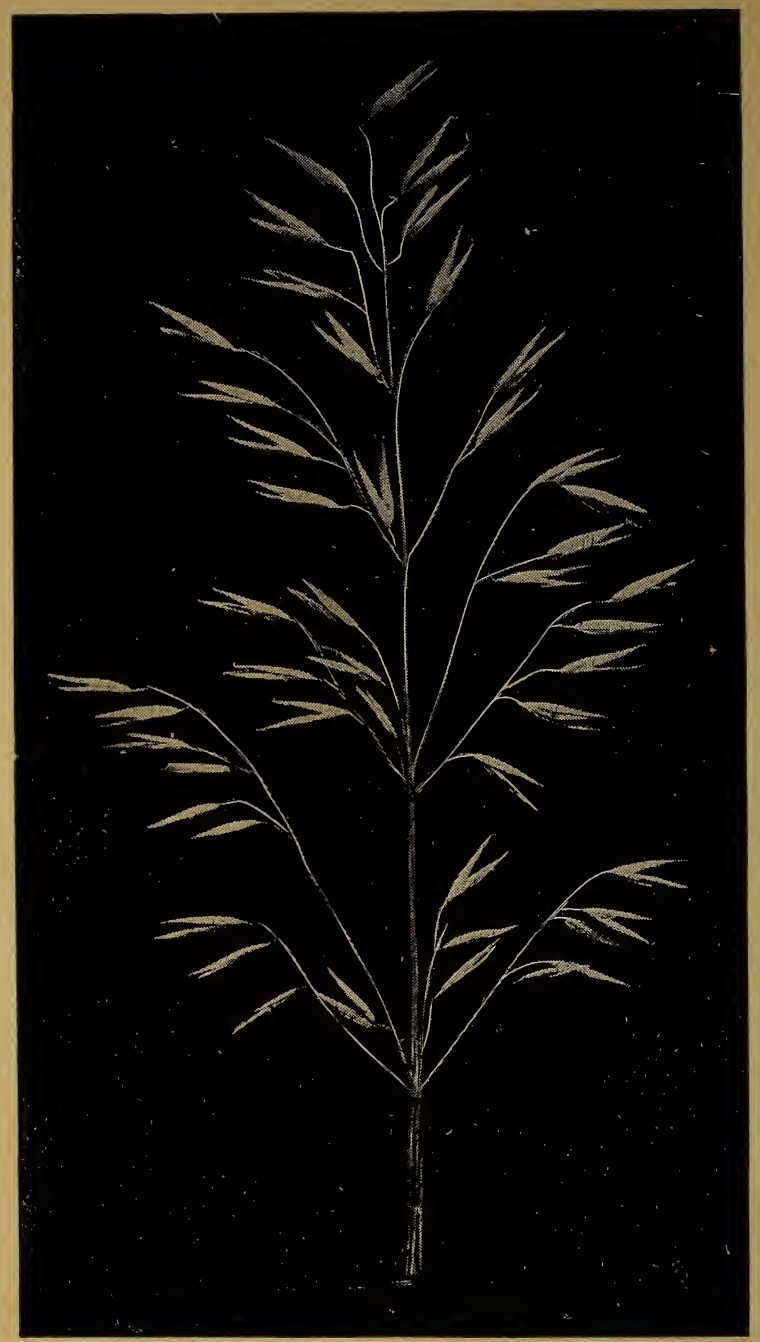

Kherson or Sixty Day Oats

The Albert Dickinson Co., Chicago-Minneapolis 


\section{Kherson and Sixty Day Oats}

Kherson and Sixty Day Oats were originally grown in adjoining provinces in Russia where soil and climatic conditions are much the same. Kherson Oats were introduced into this country by the Nebraska Experiment Station in 1897 from the Kherson government and the Sixty in 1900 by the U. S. Department of Agriculture from the Podolia government. They are very similar and perhaps identical, so that the same description may be applied to both.

Their growth is vigorous but not rank; the plants being slender and strong, and of average height. The panicle is open, medium in size, bearing from 25 to 50 spikelets. The kernels are small to medium in size, slender in shape but plump and thinhulled making them very meaty and very heavy per measured bushel. The larger kernel in the spikelet at times bears a short weak awn:, The color of the grain is from a pale yellow or almost white to a deep yellow; the intensity of color varying with weather conditions. They are among the earliest Oat varieties known, usually maturing in 70 to 90 days from the date of seeding.

An early maturing grain has more assurance of escaping rust and drought or frost in northern latitudes that often come before later maturing grains are mature.

Because of their early maturity and rather scanty foliage, they are particularly suitable to use as a nurse crop for Grass and Clover.

These Oats are more adapted to low, rich ground than most varieties for they have a less tendency to rust or lodge. There is probably no other known variety of Oats so suitable to such a wide range of soil and climate and still remain productive.

Comparative yields with other varieties over a period show the Kherson variety to be somewhat higher. 


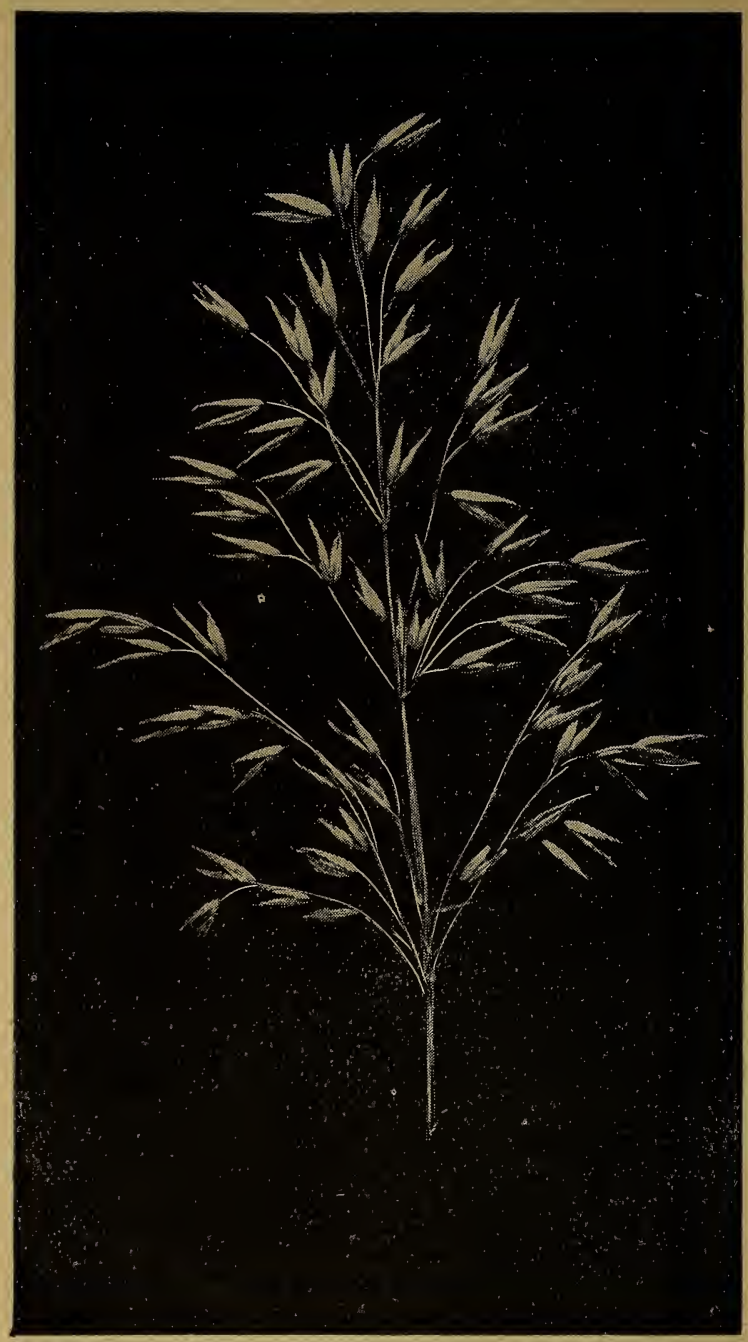

Swedish Select Oats

The Albert Dickinson Co., Chicago-Minneapolis 


\section{Swedish Select Oats}

Swedish Select Oats was introduced by the U. S. Department of Agriculture from the Moscow district of Russia in 1899 and distributed among the U. S. Experiment Stations. It is a typical white Oats with a long spreading panicle, kernels large, plump and heavy. The larger kernel in the spikelet usually grows a strong, twisted, black awn. During favorable seasons the weight per measured bushel is very high. It is a strong grower with broad leaves and stiff, tall straw, growing somewhat coarser than the Kherson and yielding more straw to the acre. This Oats is a later maturing variety, requiring 100 to 115 days to mature from the date of seeding. It is popular for its stiff straw and drought resisting qualities and its splendid ability to grow on soils of medium fertility so prevalent throughout the Northern states. Its strong, dense root system enables it to resist considerable drought. It is also a valuable variety of Oats to grow under irrigation in the Rocky Mountains and Pacific Northwest regions. It is an exceptionally good yielder of grain and produces a fine quality of straw desired by many farmers. On rich soils or during favorable conditions this variety has a tendency to lodge although not to any greater degree than many other varieties. 


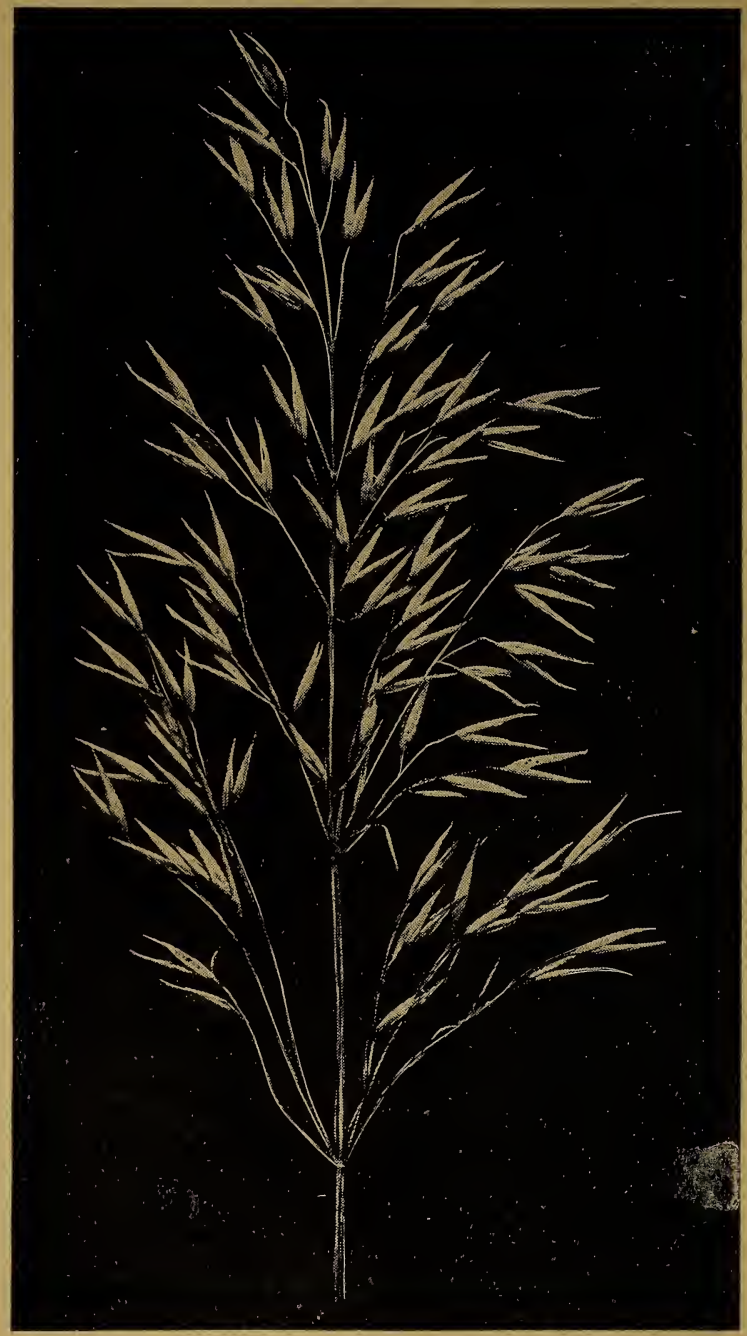

Silvermine oats 


\section{Silvermine Oats}

The Silvermine Oats were introduced a number of years ago into this country. It is one of the very best commercial varieties for the central and northern portions of the Corn belt, as well as a good variety to grow under irrigation. The characteristics of the plant of the Oats are much similar to those of the Swedish Select, averaging $4 \frac{1}{2}$ or even $5 \mathrm{ft}$. in height under favorable conditions. The kernels are also white, but are longer and slender. Panicles are rather large, varying from 35 to 60 spikelets each containing two kernels, the larger sometimes provided with a weak awn. Branches of panicles are more flexible and slender than those of the Swedish Select. It matures a few days earlier, requiring 95 to 110 days from the time of seeding. It has a less tendency to lodge than the Swedish and hence can be grown to advantage on medium to rich soils. Silvermine is a good yielder of grain and straw.

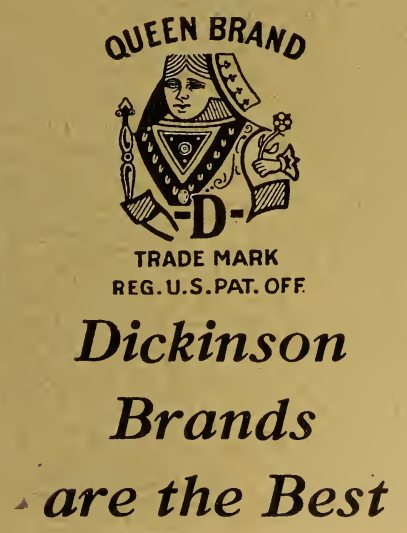

103

The Albert Dickinson Co., Chicago-Minneapolis 


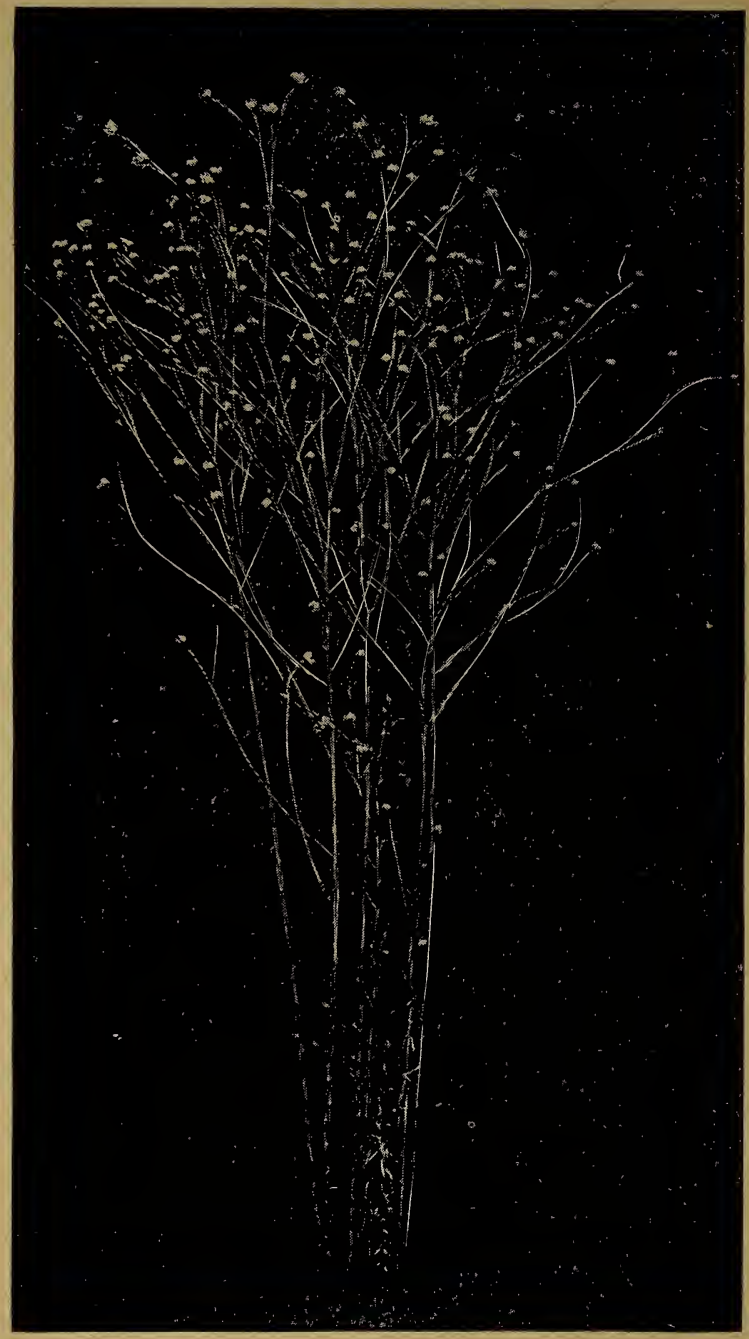

Flax

The Albert Dickinson Co., Chicago-Minneapolis 


\section{Flax}

\section{(Linum usitatissimum)}

Soil and climatic conditions of our Northern states, extending from Massachusetts to the Puget Sound, have been found well adapted for the growing of Flax for seed and fibre. Oregon and Washington have conditions particularly suitable for fibre growing. The popular idea that Flax is hard on land, depleting soil of its essential plant food elements, is without foundation. On the contrary, experiment stations have found it to be less exhaustive on the soil than either Corn or Oats.

SOIL-Soils that are successively sown to Flax become what are known as "Flax sick soils"-yielding lightly and becoming unprofitable. This difficulty is overcome by practicing a five-year rotation in which the Flax crop follows Corn. Such practice not only assures the grower a sanitary soil, but is found to be very productive. A moist, well underdrained loam, plowed in the fall and cultivated in the spring, not to exceed the Corn cultivation work of the previous year, is recommended. This prevents bringing to the surface deeply buried weed seeds, and insures a firm seed bed so essential for an even germination of the seed.

SEEDING-The time and amount to sow varies with the purpose of the crop. Flax for fibre should be sown as early in the spring as the danger from frost is past, for the cool, rapid growing months of spring and early summer tend to produce a fine long type of fibre. In this case from $1 \frac{1}{2}$ to 2 bushels are sown per acre. When sown for seed, seeding may be prolonged with success up to the $20 \mathrm{th}$ of June. The amount to sow is from 2 to 3 pecks to the acre.

The selection of plump, clean, and high germinating seed, and the disinfection of the same before seeding is highly recommended. In treating the seed use one pint or pound of formaldehyde to 40 gallons of water. 
(For complete instructions write to North Dakota Experiment Station for Press Bulletin No. 42.)

HARVESTING-Whether the crop is to be harvested for sowing or for oil purposes, care should be exercised in harvesting it as a good grade of seed is always sold at a premium on the market. It is essential to allow the seed to mature, to harvest it dry, and to keep it in a dry condition. The Flax crop is easily harvested with a self binder and is very pleasant to handle. The bundles are left in shocks until well cured, and then stored into small stacks or barns until threshing time. Flax is threshed with an ordinary threshing machine. The yields vary from 8 to 15 bushels to the acre.

Flax for fibre is pulled out of the ground either by the hand or by machinery. The straw is then tied into small bundles and shocked with the tops tied together. The butts are spread out to dry. The time for pulling is just when lowest leaves begin to drop and the stems begin to turn yellow. The few seed balls that appear with thick seeding are either removed by a coarse comb or threshed out with an ordinary threshing machine. In the latter case the operator feeds only the heads into the machine and withdraws each bundle when the seeds have been knocked off. Following this operation retting takes place-a process by which woody and gummy substances are removed. This work may be done by chemicals or by a process of fermentation or rotting.

LINSEED OIL, which is used so extensively in mixing paints, is extracted from the seed, either by the old process through pressure, as in the production of cotton seed oil, or it is dissolved out of the crushed seed with naphtha. The much prized residue-Linseed Meal-is a very valuable stock food as it is rich in protein and very easily and thoroughly digested.

A Flax crop cut just after blooming or before the development of the seeds, produces a valuable forage. It is rich in protein and contains about the same amount of fibre as timothy hay. 


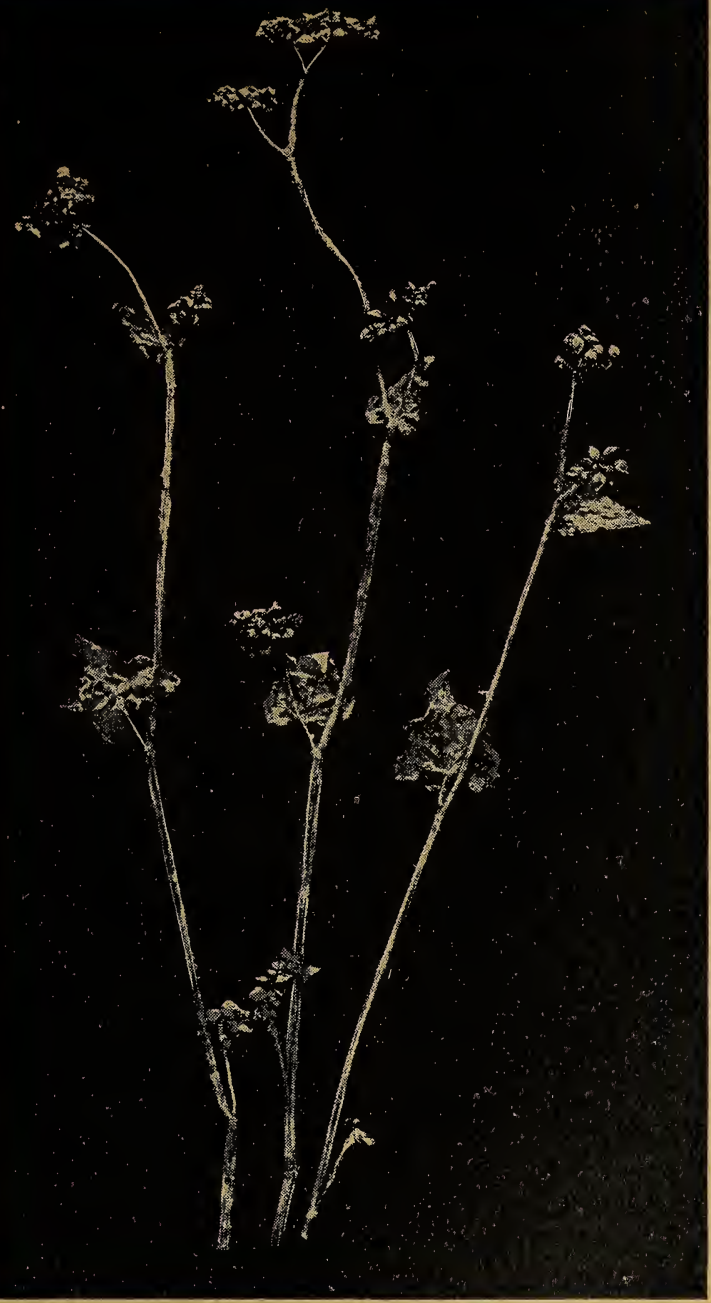

\section{Buckwheat}

The Albert Dickinson Co., Chicago-Minneapolis 


\section{Buckwheat}

(Fagopyrum esculatum)

Buckwheat is an annual, erect in habit and grows from 2 to $2 \frac{1}{2} \mathrm{ft}$. in height. It does not stool like other grains but branches out freely.

The three principal varieties commonly grown are Common, Silver Hull and Japanese. The seed of the Silver Hull is smaller and lighter in color than the Common, while the Japanese is larger than the Common, darker in color and has a tendency to extend its edges into a wing. Yields are from 30 to 40 bushels per acre. Japanese Buckwheat grows stronger and taller than the other varieties. It will also withstand more drought and produce better yields.

SolL-Buckwheat prefers a fertile, welldrained, sandy loam, though good results are obtained on soils too poor for other crops.

SEEDING-Buckwheat is rather susceptible to heat and frost at the time the grain is forming, thus planting should be delayed as much as possible, yet sufficient time should be allowed to mature the crop before frost. In the North seeding takes place from the middle of June to the middle of July. The seed is sown 2 to 3 inches deep, either in drills or broadcast. Sow from 2 to 3 pecks per acre.

HARVESTING-The plant does not ripen very uniformly. Very often the same plant bears mature and immature grains and blossoms at the same time. Cutting should take place when the first seeds ripen, for if harvesting is delayed the grain shells out profusely during the handling of the crop. The immature grain ripens in the swaths.

USES-Buckwheat requires only 70 days to fully mature from the time of seeding and on this account is frequently used as a catch crop. It is a valuable plant to turn under as green manure. It is principally used for the production of flour so desirable for 
Buckwheat cakes. The whole grain and its various by-products as well as the plant, are used to some extent for feeding purpose The crop is often grown as a bee plant; Japanese variety being most satisfactory for that purpose. The grain is also recom: mended as a poultry food, supposed to stimulate the egg laying capacity.

\section{From One Corner of \\ the Country to the Other}

The Highest Standard of Excellence Yet Attained

in

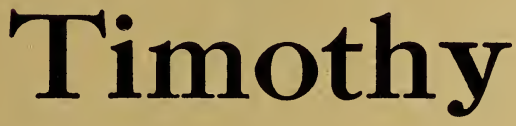

and

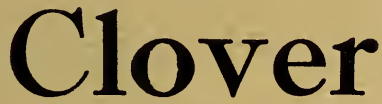

Seed

Is Recognized in the

Quality of

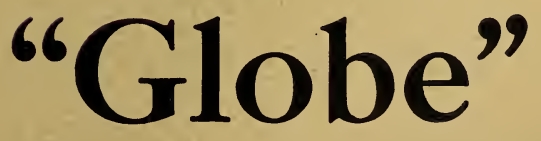




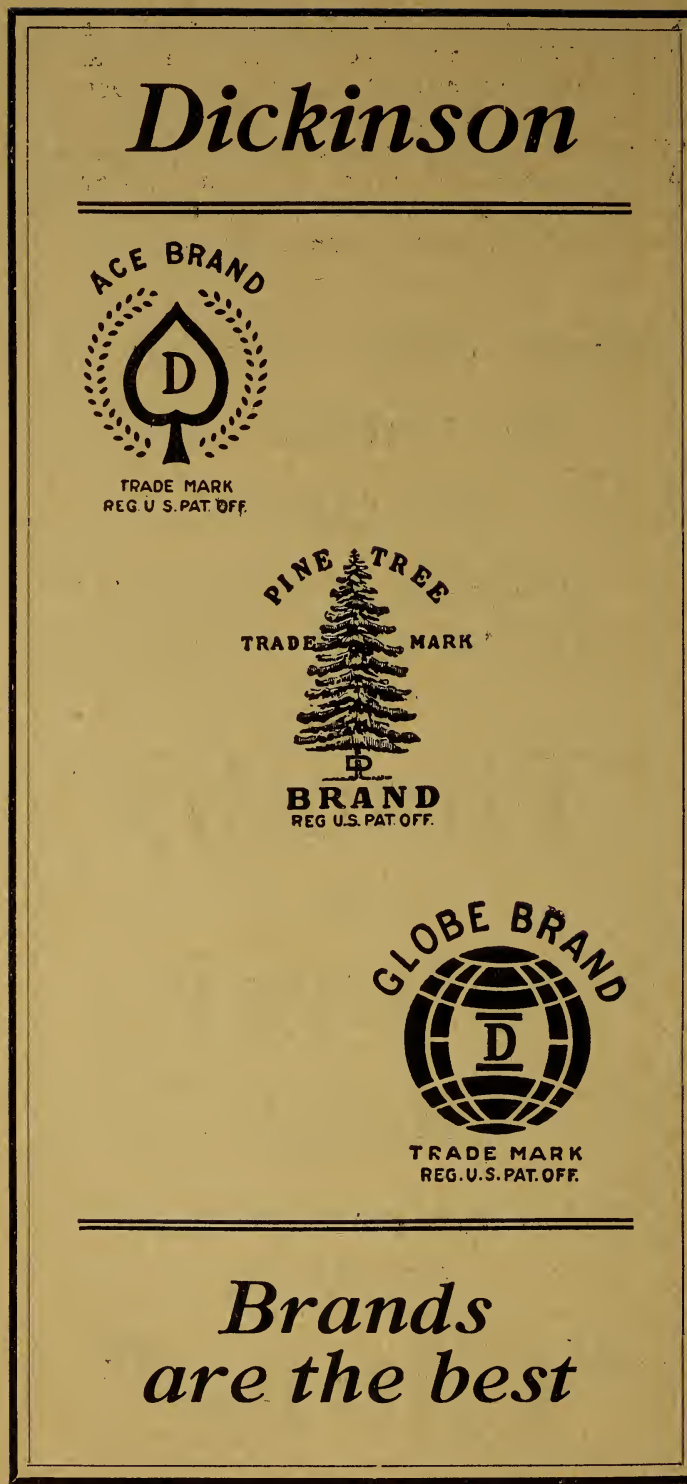

110

The Albert Dickinson Co., Chicago-Minneapolis 


\section{SEEDING}

"Successful farmers recommend heavy seeding"

$\Gamma^{\mathrm{HE}}$ quantity of seed that should be sown per acre depends on the location and nature of the soil. There is a wide difference of opinion on this subject, and the actual weight necessary must therefore be determined by some one conversant with the local situation. The table on the following page may be of service.

Spare seeding is not economical, especially where the soil is poor.

The best qualities are found to be cheapest, and pure seeds of high germinating quality are in demand more than formerly; the extra cost per acre is small and the results are more satisfactory. 


\section{Quantity of Seed Required per Acre and Customary Weights per Bushel}

\begin{tabular}{|c|c|c|c|}
\hline & $\begin{array}{c}\text { Pounds } \\
\text { per Acre }\end{array}$ & $\begin{array}{r}\text { Pou } \\
\text { per B }\end{array}$ & $\begin{array}{l}\text { unds } \\
\text { Bushel }\end{array}$ \\
\hline Alfalfa-broadcast _. & 18- 22Lbs. & & Lbs. \\
\hline Alfalfa - drilled & $15-20$ “ & & \\
\hline Barley -:-:-1- & $95-110 ،$ & 48 & “ \\
\hline Beans - in hills & $20-35$ “ & 60 & “ \\
\hline Blue Grass, Kentucky_- & $35-40$ “ & 14 & “ \\
\hline Blue Grass, Canada ..... & $35-40 ،$ & 14 & “ \\
\hline Brome Grass - alone for hay & $18-20$ “6 & 14 & “ \\
\hline Brome Grass-alone for pasture... & $20-25 “$ & 14 & “ \\
\hline Broom Corn & 36 “ & 48 & “ \\
\hline Broom Corn-for seed... & 12 “ & 48 & “ \\
\hline Buckwheat_........ & $60-70 ،$ & 52 & “ \\
\hline Clover, Alsike - alone for forage & $8-15 “$ & 60 & “ \\
\hline $\begin{array}{l}\text { Clover, Alsike - on wheat or rye in } \\
\text { spring }\end{array}$ & 4- 6 66 & & “ \\
\hline Clover, Mammoth & $12-15$ “ & 60 & “ \\
\hline Clover, Red-alone for forage & 16 “ & 60 & “ \\
\hline Clover, Red-on small grain in spring & 8- $14^{66}$ & 60 & “ \\
\hline Clover, Sweet-hulled_._. & $20-30$ “6 & 60 & “ \\
\hline Clover, Sweet-unhulled__._. & $30-40 " 6$ & 33 & “ \\
\hline Clover, White & 10- $12 “$ & 60 & “ \\
\hline Corn - & 10- $12 “$ & 56 & “ \\
\hline Corn-for silage & $30-35 “$ & 56 & “ \\
\hline Cow Peas-broadcast.. & $80-120$ & 60 & “ \\
\hline Cow Peas-drilled ...- & $45-60 " 6$ & 60 & “ \\
\hline Crimson Clover & $12-15 “$ & 60 & “ \\
\hline Canada Field Peas-broadcast _... - & $150-160 “$ & 60 & “ \\
\hline Canada Field Peas - with oats _._.- & $90-100 “$ & 60 & “ \\
\hline Flax -for fibre & $75-110$ “ & 56 & “ \\
\hline Flax_for seed _.... & $35-45 “$ & 56 & “ \\
\hline Grass-for lawns _. & 3- 5bus. & 14 & “6 \\
\hline Hungarian Millet-for hay & 40- Lbs. & 48 & “ \\
\hline Hungarian Millet - for seed & 25- & 48 & “ \\
\hline Kafir-drills _...-. & $3-6$ 6 & 56 & “6 \\
\hline Kafir - for fodder & $10-12$ & 56 & 6 \\
\hline Meadow Fescue & $15-20 “$ & 24 & “" \\
\hline Millet, Common-for hay & 40 “ & 50 & \\
\hline Millet, Common-for seed & $25 "$ & 50 & 6 \\
\hline Millet, German-for hay _. & $40 ،$ & 50 & \\
\hline Millet, German-for seed & $25 “$ & 50 & \\
\hline Millet, Siberian-for hay & 40 “6 & 50 & 66 \\
\hline Millet, Siberian-for seed _......- & $25 “ 6$ & $\begin{array}{l}50 \\
25\end{array}$ & 6 \\
\hline Millat. . Iananes & & & \\
\hline
\end{tabular}


Quantity of Seed Required per Acre and Customary Weights per Bushel

(Continued)

\begin{tabular}{|c|c|c|c|c|}
\hline \multirow[b]{2}{*}{ 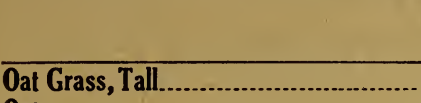 } & \multicolumn{2}{|l|}{$\begin{array}{c}\text { Pounds } \\
\text { per Acre }\end{array}$} & \multicolumn{2}{|c|}{$\begin{array}{c}\text { Pounds } \\
\text { per Bushel }\end{array}$} \\
\hline & & Lbs. & & Lbs. \\
\hline Oats & $70-100$ & “ & 32 & “ \\
\hline Orchard Grass.. & 25- 35 & “ & 14 & “ \\
\hline Pasture Mixture.. & 40- 42 & “ & & \\
\hline Rape -in drills... & 2- 4 & “ & 50 & “ \\
\hline Rape-broadcast.... & 4- 8 & “ & 50 & “ \\
\hline Red Top-solid seed. & 14- 18 & “ & & \\
\hline Red Top-in chaff.... & 30- 40 & “ & 14 & “ \\
\hline Rye-early & $55-65$ & “ & 56 & “ \\
\hline Rye - late.......... & $75-112$ & “ & 56 & “ \\
\hline Rye-forage...... & $175-200$ & “ & 56 & “ \\
\hline Rye Grass, Italian..... & $40-50$ & “ & 24 & “ \\
\hline Rye Grass, Perennial.. & 40- 50 & “ & 24 & “ \\
\hline Sheep's Fescue & 35- 45 & “ & 14 & “ \\
\hline Slender Wheat or Western Rye Grass.. & 20 & “ & & \\
\hline Sorghum, Forage - broadcast........... & $75-100$ & “ & 50 & “ \\
\hline Sorghum-for seed or syrup...... & $2-5$ & “ & 50 & “ \\
\hline Soy Beans - drills................ & $30-40$ & “ & 60 & “ \\
\hline Soy Beans - broadcast................. & $60-80$ & “ & 60 & “ \\
\hline Sweet Corn-in drills for fodder. & 75 & “ & 46 & “ \\
\hline Sweet Corn-broadcast.............. & 150 & “ & 46 & “ \\
\hline Timothy & 15- 25 & “ & 45 & “ \\
\hline Timothy and Clover & & & & \\
\hline Timothy ) & 10 & “ & & \\
\hline Clover $\}$ & 4 & “ & & \\
\hline $\begin{array}{l}\text { Vetch, Hairy-drilled (plus one bus. } \\
\text { small grain) }\end{array}$ & 60 & “ & 60 & “ \\
\hline $\begin{array}{l}\text { Vetch, Hairy -broadcast (plus one bus. } \\
\text { small grain) }\end{array}$ & 80 & “ & 60 & “ \\
\hline Vetch, Spring (plus one bus. small grain) & 80 & “ & 60 & “ \\
\hline 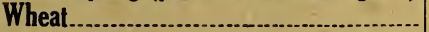 & $90-120$ & “ & 60 & “ \\
\hline Wheat -Durum............... & 45- 75 & “ & 60 & “ \\
\hline Wheat-Emmer or Speltz... & $60-125$ & “ & 42 & “ \\
\hline
\end{tabular}

\section{BUY THE BEST SEED YOU GAN BUY}

BUY DICKINSON'S BRANDS 


\section{Globe Chick Feed}

A Complete Grain Feed for Chicks

\section{Globe Developing Feed}

An Intermediate Feed for Growing Chicks

\section{Globe Egg Mash}

A High Protein Feed for Winter Layers

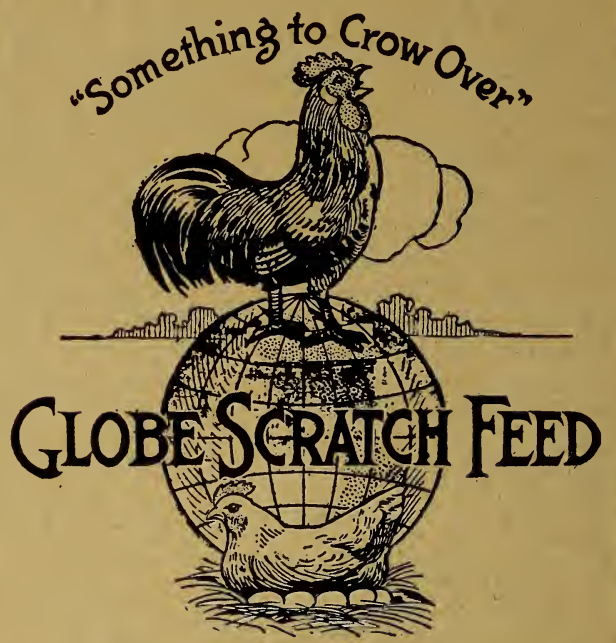

A Balanced Grain Ration Poultry Feed for Grown Fowls

SUITABLE AT ALL SEASONS

CLEAN-SOUND-SWEET

Insist upon these brands. Twelve years of proved success. If your dealer does not carry these brands write us for samples.

\section{ASK YOUR DEALER}




\section{Dickinson's Snowball Pop Corn}

The contents of ono package are equal to eight quarts of popped corn.

Recipes on each package. Price, ten cents the package

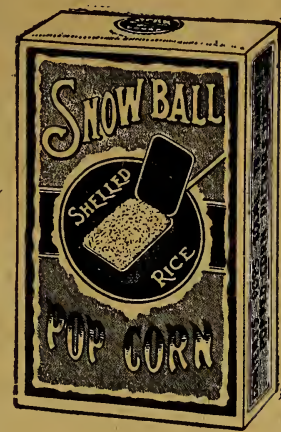

The corn is shelled from especially selected ears, carefully cleaned, so that it is uniform and freo from dirtReady for the Popper

Who does not recollect with pleasure, bleak wintry afternoons enlivened by a dish of deliciously flavored Pop Corn? Or, the added cheerfulness supplied by this danty delicacy at picnics, parties or evenings at home?

In our experience no other confection has to such a degree this quality of infusing so generously, true, inspiring cheerfulness.

One of the sacred duties of parents is to provide for the children an atmosphere of gaiety and happiness. Cheerfulness is the very fountain of enthusiasm-and enthusiastic children are healthy children!

Furthermore, even if eaten freely; Pop Corn will not harm children. That's a reason why it is preferable to peanuts and candy. It is nutritious and healthful, too.

If you would have your childhood days brought vividly back to you, buy immediately a package of

\section{SNOWBALL Ask Your Grocer}




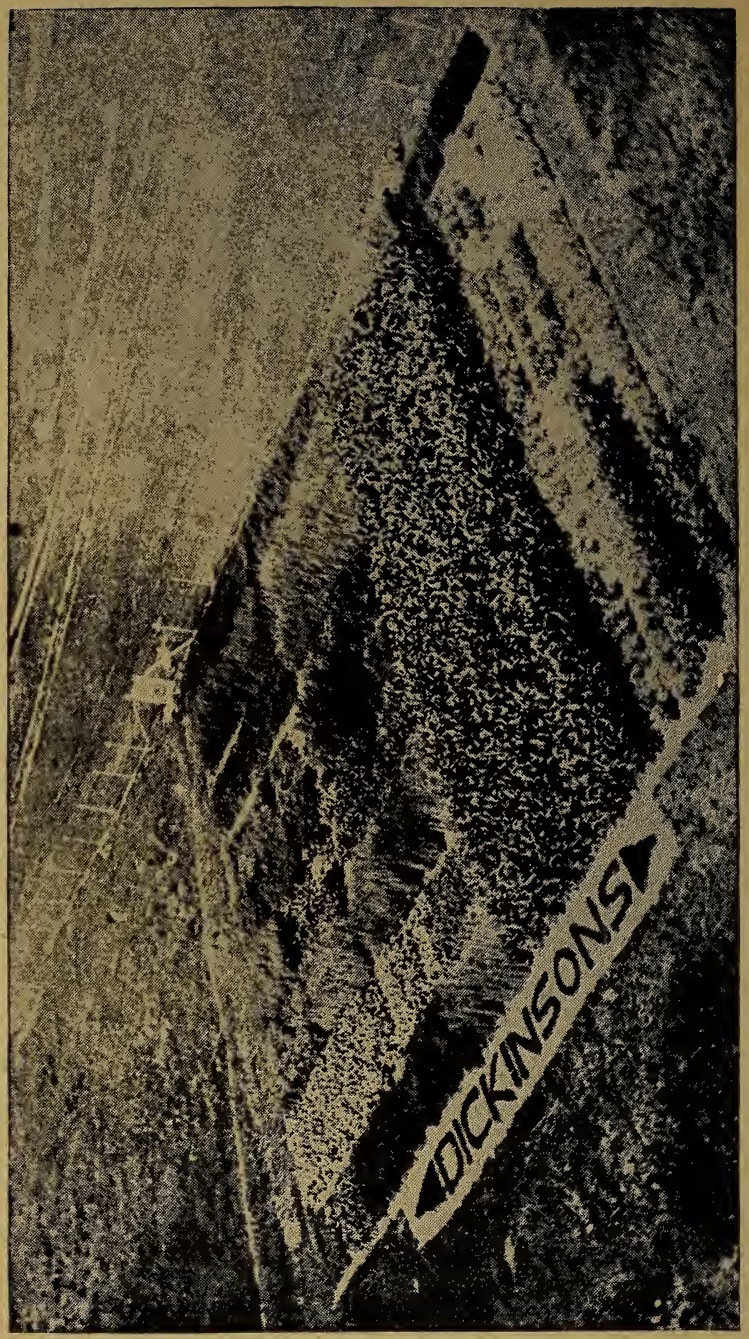

This Dickinson Test Plot is located alongside of our Minneapolis Seed Cleaning Plant and Offices. This is where experiments and tests are conducted by our Expert Seed Analyst and Agronomist. 


\section{INDEX}

Name

Page

Alfalfa

16- 19

Alsike $. . \ldots \ldots \ldots \ldots \ldots \ldots \ldots \ldots, 10.11$

Amber Cane $. . . \ldots \ldots \ldots \ldots \ldots . .6$. 70- 71

Barley .................... 91- 93

Buckwheat ................. 107-109

Clover, Crimson .............. 22- 23

Clover, Mammoth ............. 8- 9

Clover, Medium Red ........... 5- 7

Clover, Sweet ............... 20- 21

Clover, White ............... 12- 13

Cow Peas $. . . \ldots \ldots \ldots \ldots \ldots \ldots . . .6$ 32- 34

Dwarf Essex Rape ............ 72- 73

Emmer, also called Speltz ....... 88- 90

Field Peas ................ 26- 28

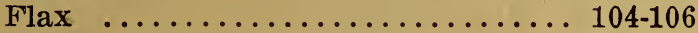

Grass, Canada Blue ............. 44- 45

Grass, Kentucky Blue ........... 42-43

Grass, Italian and Perennial ....... 35- 37

Grass, Orchard .............. 48- 49

Grass, Slender Wheat or Western

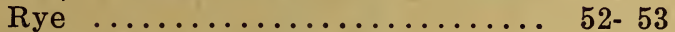

Grass, Smooth Brome ......... 50-51

Hairy Vetch ................ 24- 25

Legume, Inoculation ........... 14- 15

Meadow Fescue .............. 38- 39

Millets ................ 54- 55

Millet, Broom Corn ............ 67-69

Millet, Common .............. 60-61

Millet, German .............. 58- 59

Millet, Hungarian..$\ldots \ldots \ldots \ldots \ldots$. 56- 57

Millet, Japanese $\ldots \ldots \ldots \ldots \ldots \ldots \ldots$ 64- 66

Millet, Siberian ............ 62-63

Oats..$\ldots \ldots \ldots \ldots \ldots \ldots \ldots$ 9........ 97

Oats, Kherson or Sixty Day....... 98- 99

Oats, Silver Mine ............ 102-103

Oats, Swedish Select .......... 100-101

The Albert Dickinson Co., Chicago-Minneapolis 


\section{INDEX-Cont.}

Name

Quantities per acre, and weight per

bushel ................... 112-113

Red Top ................ 46- 47

Rye .................... 94- 95

Seeding .................... 111

Soy Beans $\ldots \ldots \ldots \ldots \ldots \ldots \ldots$ 29-31

Timothy $\ldots \ldots \ldots \ldots \ldots \ldots \ldots \ldots$ 4 $40-41$

Wheat.$\ldots \ldots \ldots \ldots \ldots \ldots \ldots \ldots$ 74. 75

Wheat, Bluestem ............ 78- 79

Wheat, Durum $\ldots \ldots \ldots \ldots \ldots \ldots$. 86- 87

Wheat, Emmer, also called Speltz. . 88- 90

Wheat, Fife $\ldots \ldots \ldots \ldots \ldots \ldots \ldots$. $76-77$

Wheat, Marquis ............. 80-81

Wheat, Preston (Velvet Chaff) ......82-83

Wheat, Turkey Red ........... 84-85

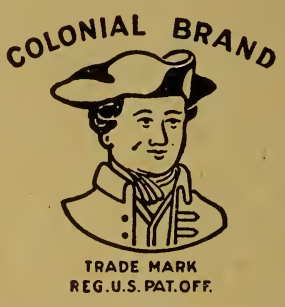

Dickinson Brands

are the Best 


\section{Memoranda}

The Albert Dickinson Co.; Chicago-Minneapolis 


\section{Memoranda}

$\overline{\text { The Albert Dickinson Co., Chicago-Minneapolis }}$ 


\section{DICKINSON'S Seeds of Quality}

FOR SALE BY 